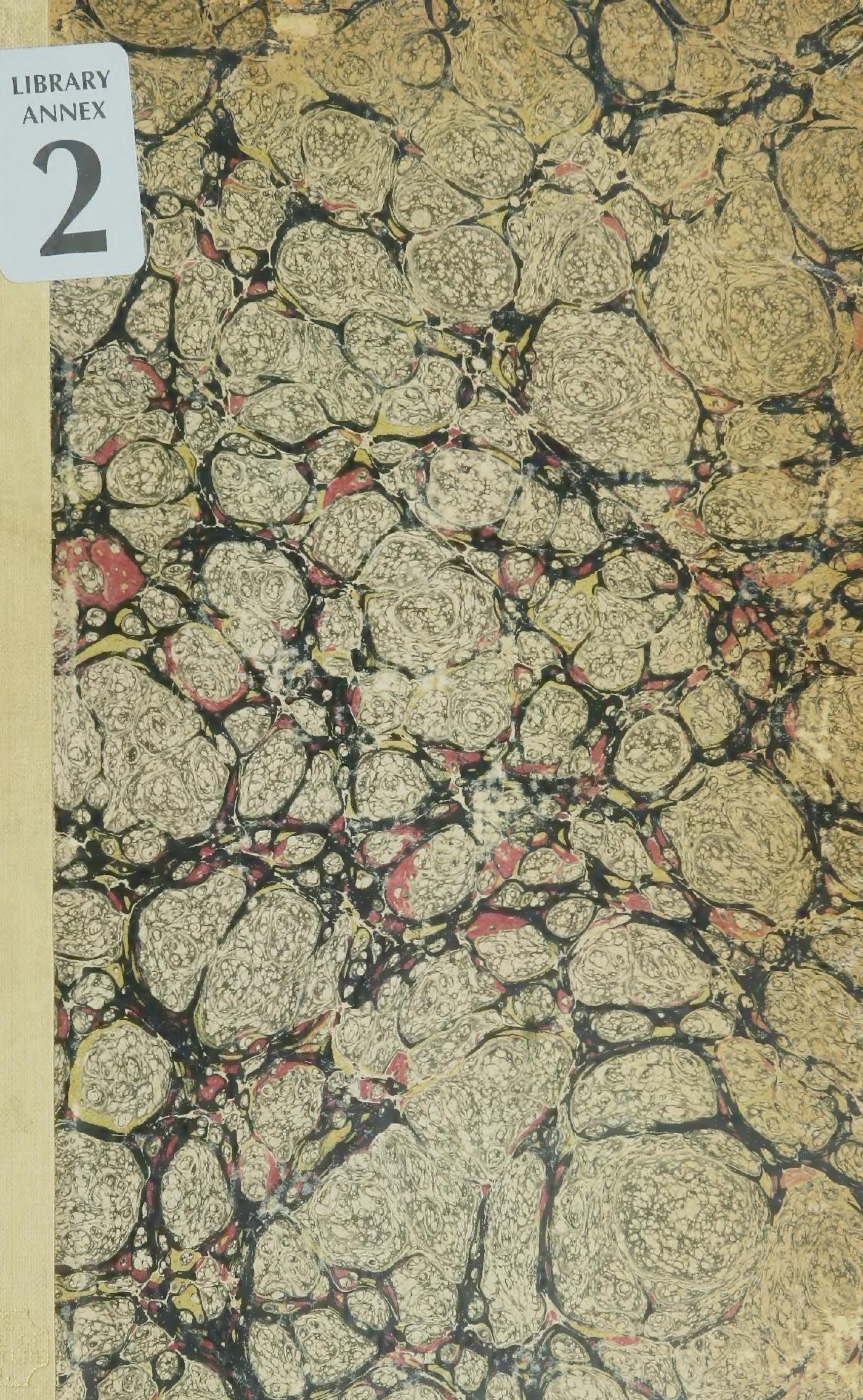




\section{Cornell Universite}

\section{Libraip}

OF THE

Hew Dork Ftate College of Elgriculture

$A_{\varepsilon .2960}$ 2610711 


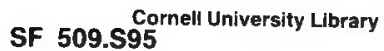

The reliable pheasant standard; a practic

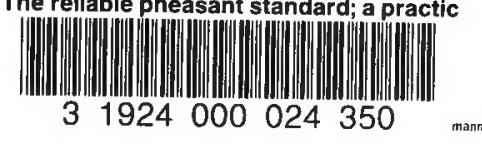


.

- 

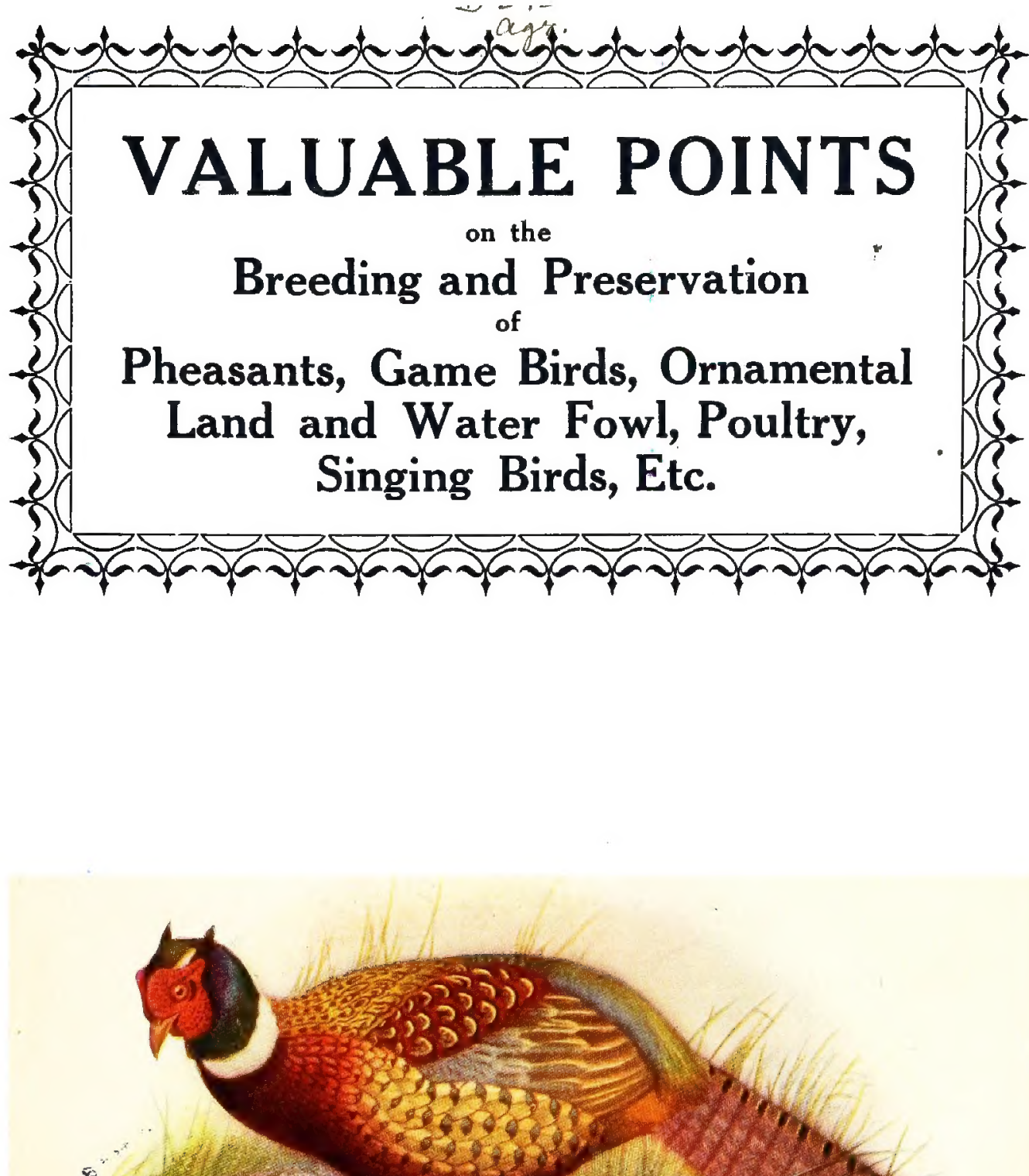


\section{Cornell University Library}

The original of this book is in the Cornell University Library.

There are no known copyright restrictions in the United States on the use of the text. 


\section{The \\ Reliable Pheasant Standarı \\ The Recognized Authority}

\section{A Practical Guide}

on the

Culture, Breeding, Rearing, Trapping, Preserving, Crossmating, Protecting

Stocking, Hunting, Propagating, Etc.

of

Pheasants, Game Birds, Ornamental Land and Water Fowl Singing Birds, Etc.

Valuable Recipes for Poultrymen

"The Secret to Make Hens Lay in Winter"

B Y FERD. J. $\stackrel{S}{S}$ U D O W

Adding the experience of several other Successful Breeders

THIRD EDITION

ENLARGED

PROFUSELY ILLUSTRATED

COLORED PLATES

COPYRIGHT 1910, POUGHKEEPSIE, N. Y.

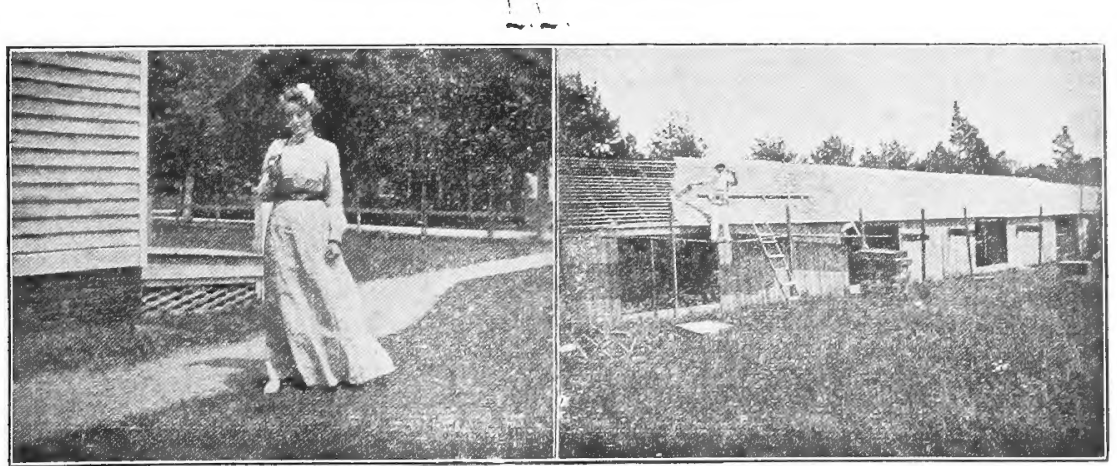




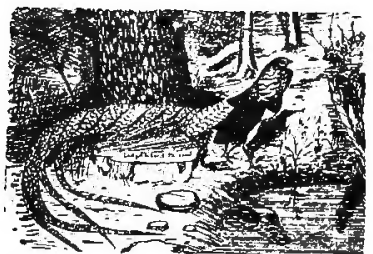

\section{$>1 \sim \sim 1$ \\ $S 95$ \\ CONTENTS}

(Third Edition)

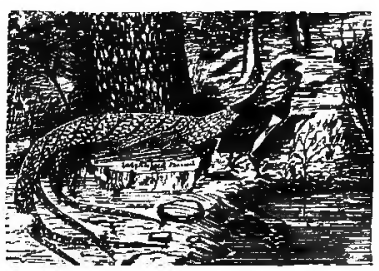

The articles and illustrations in this book appear in the following order:

Pheasants for Zoological Parks ........... PAGE

General History and Management of Pheasants ... 15

The care and breeding of matured Pheasants . . . . 16

A few hints on good health............. 17

Method of raising Pheasants successfully....... 18

Hybrid Pheasants.................. 18

Barrel nest and practical Pheasant coop....... 19

Pheasant breeding yields an enormous profit.... 21

A fortune to an industrious breeder . . . . . . 21

Recipe for cold and roup . . . . . . . . . . . 23

An ideal Pheasantry and practical gate....... 24

Colored plates of Pheasants ............. 25

Ideal poultry house, scratching pen and cat

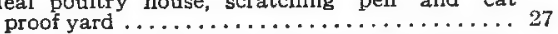

Amherst Pheasants displaying their striking plumage during breeding season. . . . . . . . . . 27

Cat proof yard and fence................ 28

A hawk protector...................... 29

How to ship Pheasants................ 30

A telegram from California in May.......... 31

Pheasant market. . . . . . . . . . . . . . 31

To keep Pheasants from straying . . . . . . . 31

Trapping Pheasants.................. 31

Crows the worst enemies of Game Birds...... 31

For Sportsmen nothing exceeds Pheasant shooting 33

A morning Pheasant shoot . . . . . . . . . . . . 32

Pheasants as insect destroyers. . . . . . . . . 32

A wonderful industry................ 33

How to attract birds..................... 33

Australian Crown Pigeons, Scotch Grouse, Scaled and Siberian Partridges and Prairie Chickens... 36

Notes from another Pheasant fancier . . . . . . . 37

Pheasants the friend of the farmer.......... 35

A practical rat trap.................. 39

Recipes for something good to eat besides Pheas-

ants........................... 41

Colored plates of Pheasants. . . . . . . . . . 43

Stuffed Pheasants for mounting purposes..... 46

Pheasant breeding in America by J. Alden Loring.. 47

Description of Pheasants................ 54

Great Argus Pheasant. . . . . . . . . . . . . . 54

Impeyan Pheasant.................. 54

Peacock Pheasant. . . . . . . . . . . . . . 55

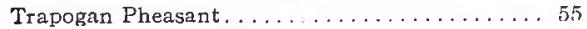

Versicolor Phensant. . . . . . . . . . . . . . 56

Fireback Pheasant................. 56

Chinese or Ring Neck Pheasant. . . . . . . . . . . 57

Silver Pheasant.................... 57

Golden Pheasant................... 58

Elliott Pheasant................... 58

Manchurian Pheasant. . . . . . . . . . . . . . . . 59
Lady Amherst Pheasant. .............. 59

Swinhoe Pheasant. ...................6 60

Soemmering Pheasant. ................60

Full-page colored plates of Pheasants. . . . . . 62

Reeves Pheasant.....................63 63

Japanese Pheasant. . . . . . . . . . . . . . . 64

Black Neck Pheasant. . . . . . . . . . . . . . 65

Common Pheasant..................65

Reeves Pheasant....................66 66

Siamese Pheasant. . . . . . . . . . . . . . 66

Melanotus Pheasant . . . . . . . . . . . . . 66

Mongolian Pheasant . . . . . . . . . . . . . 66

Prince of Wales Pheasant. . . . . . . . . . . . 67

Hagenbeck Pheasant. . . . . . . . . . . . . . 67

All about tails. . . . . . . . . . . . . . . . . 67

Testimonials...................... 68

Messina and California Quail. . . . . . . . . 69

Mandarin and Wood Duck breeding. ......... 70

Swimming pool for Mandarin and Wood Ducks. . . 70

Squirrels......................... 71

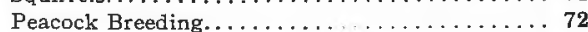

Auerhahn or Capercailzies... . . . . . . . . 72

Vultrine Guinea Fowl. . . . . . . . . . . . . . 73

Jungle Fowl. ..................... 73

A practical poultry house with scratching shed ...74

The secret to make hens lay in winter . . . . . . 74

A little severe talk on crows. . . . . . . . . 75

Japanese Long Tail Phoenix Fowl .......... 75

Artificial nests for singing birds. . . . . . . . . 76

How to trap sparrows . . . . . . . . . . . . 76

Pheasant capons.................. 77

Hungarian Partridges................ 78

Colored plate of Belgian Homers. . . . . . . . . 80

European Roe Deer.................... . 81

Rabbit breeding................... 82

A Quail and Partridge trap . . . . . . . . . . 83

Angora Goats................... 83

Bohemian Quail, Swiss Chamois........... 84

Ostrich Breeding ................... 85

Swan Breeding. ................. 87

Indian Runner Ducks. .................. 88

Deer Farming . . . . . . . . . . . . . 89

Japanese Ring Doves, Cuban and Wonga Doves... 90

Questions and answers, A trap for game........ 91

Wild Turkeys..................... 92

A long, wearisome letter.............. 92

Egyptian Geese, Canadian Geese,

Most practical Pigeon nests. . . . . . . . . . . . . 93

New discovery for the destruction of rats and

mice ........................ 9 


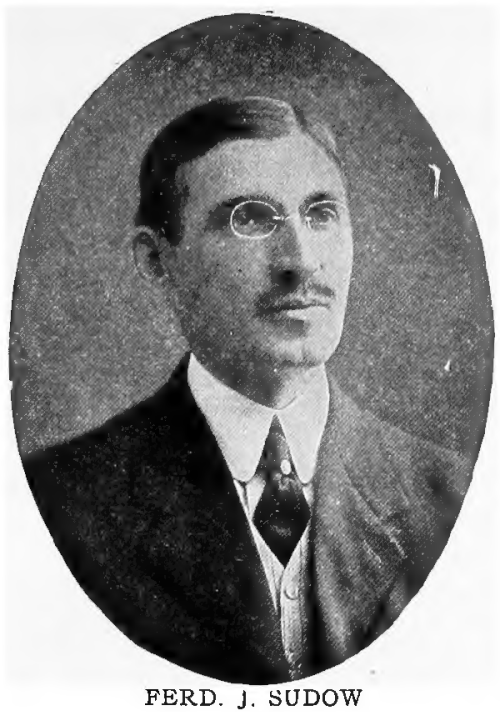

\section{INTRODUCTION}

For a number of years $I$ have been a most enthusiastic admirer and breeder of pheasants, ornamental birds and game, and always on the look-out for new innovations in thisline. I have corresponded with many fanciers on the subject and collected all the information possible. The results of my practical experience, I will endeavor to render in plain words and short sentences as explicit as possible in this little book.

The artificial culture of pheasants and Game birds is not entirely a new one; yet it will attain more popular attention when it becomes known what pleasure and profit can be derived from this grand industry under proper management. The fancier who wishes to keep these birds, take an interest in them, and make them happy. It is my purpose in writing this book to give as clearly and plainly as possible the needful instruction for the culture and management of these birds. I believe once started, the fascination, pleasure and profit will not let you abandon this beautiful industry again.

Very truly yours,

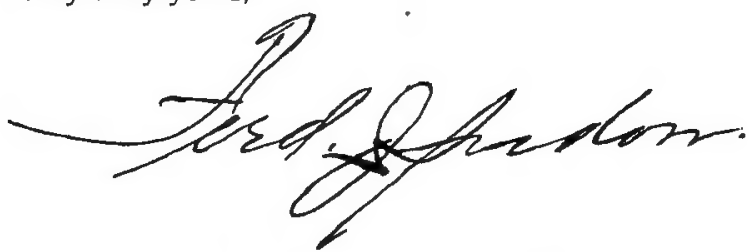

Poughkeepsie, N. Y.

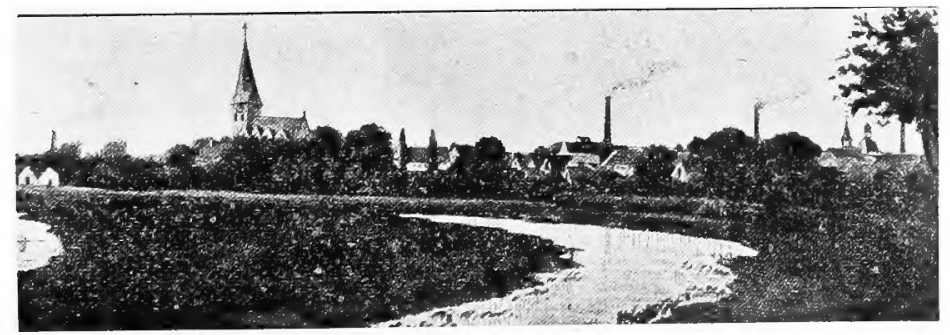

HASELÜNNE, PROVINCE HANNOVER, GERMANY Birthplace of the Author 


\section{Pheasants for Zoological Parks}

Pheasants are of great amusement, education and pleasure to the children, because

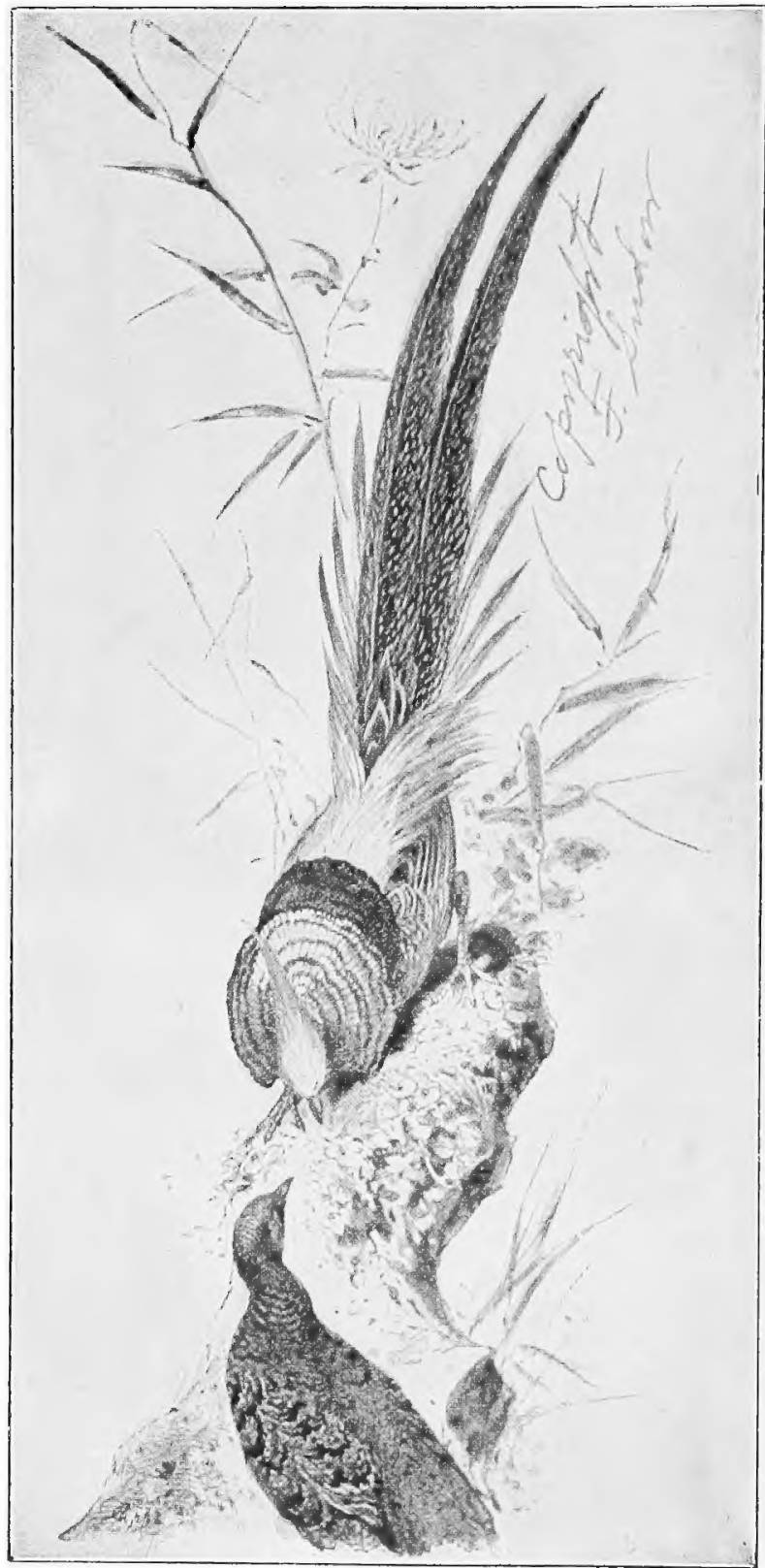
they are always on the move showing their magnificent, gorgeous plumage and displaying it in all kinds of shapes and forms. Nothing excels a complete variety of the 34 breeds of Pheasants for exhibition or as an attraction for Zoological purposes. It would beautify every city and town to establish a public Pheasant Park; be of immense pleasure to the young folks and of great interest to the community at large.

Without a doubt a donation of a pheasant park will be considered a great charitable act as well as a memorial. Will also be a grand educator. 


\section{General History and Management of Pheasants}

Pheasant breeding in the United States is still in its infancy, although it has become quite popular in the east of late years and will soon be prominently introduced all over the country. The pheasant is of a most noble and beautiful form, attractive head, stout bill, short wings, elegant long tail adorned with brilliant golden spangled plumage. One breed more beautiful than others. Printers cannot describe pheasants; an artist can only give a faint idea of these gorgeous birds with their magnificent combination of colors, and the most graceful figure, style and action. Anyone having a high appreciation of the beautiful cannot fail to be an admirer only, but a true pheasant fancier. A visit to an aviary containing varieties of the pheasant family will convince you that they are not a picture dream, but one of Nature's charms to the eye. They are of ancient origin and they have been found in many parts in the world.

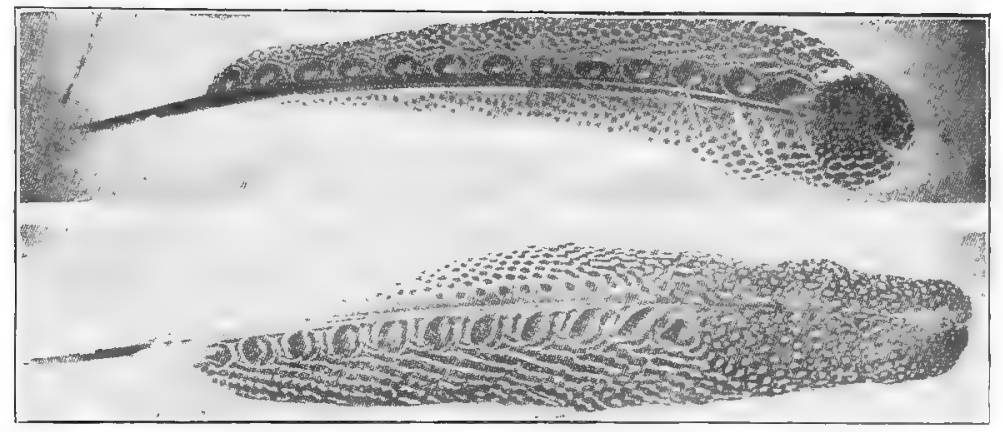

FEATHERS OF THE GREAT ARGUS PHEASANT

The pheasant will eat almost anything,-grain, herbage, roots, berries, insects,--small food of any kind. Ants are the most favorite food and the chief support of the young. They also eat green weeds, tender shoots of grass, cabbage, young clover, wild cress. They relish grapes, and in the fall of the year, ripe seeds are their chief food.

In Oregon, where Ringneck Pheasants were set at liberty about thirty years ago, they have become quite common. Their favorite haunts are low grounds near fields of grain. They are very prolific, - a pair will hatch from forty to fifty eggs and raise most all the young.

An interesting fact is that the Golden Pheasants have also become wild in Oregon and the flesh is found very white and tender. A Golden Pheasant is a great ornamental aviary bird, and to a country estate, it is difficult to imagine any greater attraction.

In the Eastern States, Ringneck Pheasants are, in certain localities, doing very well. As many as three thousand birds have been reared and turned out by a single keeper, and the pheasant is generally regarded as the future game bird of the country. The bird can stand, not only the extreme heat of summer, but the severe cold and blizzards of winter. A number of game clubs have been formed for their protection, and large numbers are now raised on Long Island preserves. They are also branching out in many parts of New Jersey, Connecticut, New York, Ohio, Illinois, Indiana and Colorado. All game commissioners are encouraging their breeding, and the outlook for the handsomest and most delicious game bird is quite rosy in this country.

Beautiful postal cards in colors of Pheasants, Ducks, Game, etc., 40c per 50, and a scheme how to make money "Quick", by mail, goes with them.

FERD. J. SUDOW, Poughkeepsie, N. Y. 


\section{The Caring and Breeding of Matured Pheasants}

To exclude sparrows from pheasant yards-and prevent them from eating two-thirds of the feed-one-inch mesh wire should be used, and put five inches in the ground. A breeding pen for a pair or trio should be about $10 \times 12$ feet, seven feet high, covered top, with a shed facing south in which the sand is banked four inches answering as a dust bath. It is absolutely necessary for birds to bathe in dust in order to keep a fine, glossy and clean plumage. The entire front of the shed should be left open. I plant small live evergreen or cedar trees for shade in this run, and during the breeding season put the perches very low (made of $1 \frac{1}{2} \times 3$ inch lumber, in the shed only), to avoid eggs being broken if dropped during the night, and prevent egg eatcrs.

Pheasants are very intelligent birds. If they once get a taste of eggs they will most generally eat them during that season, in which case the only way to save the pheasant eggs is to keep a lot of chicken eggs before them, which they prefer to eat to their own.

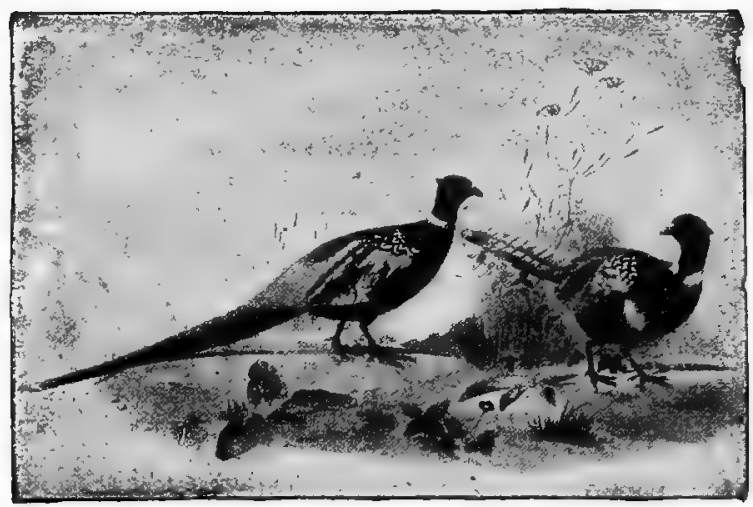

CHINESE MONGOLIAN PHEASANT

Another good way to prevent both eating of eggs and plucking the feathers from each other, is the practice of giving a portion of well crushed bone regularly.

Sometimes a cock appears very cruel to his hens and drives them too much. As a prevention, connect his legs by a piece of soft string, long enough for him to walk easily, but not to run. By doing this the hens are allowed a chance to escape his cruel treatment. Again, another easy remedy is to cut off the point of the cock's bill hindering him from peching the hen on the head. A pheasant cock will mate with two or three hens.

I do not approve of more than one cock in a breeding pen; they are great fighters and fight till death. Although cocks left without hens apparently are quite peaceable; a great jealousy exists among cocks when put with hens. I advise changing cocks from time to time in the breeding pen, in order to produce strong chicks, and every egg laid to be fertile. Pheasants are of very hardy constitution and will stand most any kind of weather and not take much shelter. Diseases so common among chickens, such as roup, etc., very seldom occur among pheasants. For best egg results feed lots of good heavy oats and greens: occasionally a little mash mixed of bran, ground oats, cut clover, beef scraps, sprinkled with a pinch of PRATT'S Poultry Food. I do not feed corn from February until August. 
To illustrate how much depends on feeding, a neighbor of mine one season fed corn exclusively, kept it before the birds permanently and realized nine eggs of a Silver Pheasant hen, where I succeeded to average 51 eggs of each silver hen during same season. Pheasant hens commence to lay in April to August. They make their nests by digging a hole in the ground. Varieties of pheasants lay from 10 to $80 \mathrm{eggs}$ in a season. After the breeding season is over and during the winter I feed principally corn, cabbage and apples, and put lots of cornstalks along the west and north fence of run for shelter and have lots of pine needles on the ground; it helps to melt the snow quickly and keeps the birds off the wet ground. I do not use boards at the bottom of south side of pen, as I want to give as much sunshine as possible to the aviary. Pheasants should always be caught with a scap-net and taken up by the body, as the legs are very easily broken. It is a good idea to clip one wing short in order to keep them from flying heavily against the wire, for they are apt to kill themselves in this way. If minks or weasels are in the neighborhood, one-inch mesh wire should absolutely be used for three feet at the bottom of the pen, keeping these devils out and put six inches in the ground to keep dogs out. I know an occasion where a mink killed 41 pheasants in one night.

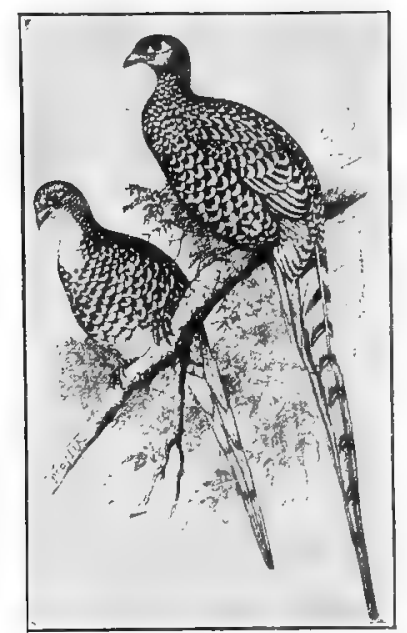

SOEMMERING-JAPANESE COPPER PHEASANT

\section{A Few Hints on Good Health}

Instead of coffee or tea, drink cocoa shells; costs $3 c$ pound, enough for a month. A wonderful tonic for the nerves.

Walk erect, throw out your chest. Breath through the nose.

Use freely of Italian Olive Oil for all purposes. Drink it. Rub it on the body. behind the ears, on the soles of the feet, palms of the hands, etc. Oil will preserve life, vitality and strength in the human system the same as in machinery. Use it every day. When a cold comes on you, snuff olive oil up your nostrils every hour. It will effect a cure in 12 hours.

For cold and wet feet take a hot foot bath. It is beneficial for all purposes.

To retain an active liver, drink at least three glasses of water a day. 


\section{Method of Raising Pheasants Successfully}

Pheasant hens, during confinement, are very poor mothers and do not seem to have much natural love for their young. Therefore, to raise them successfully, small common chicken hens are used. I find a hen of soft, fluffy feathers an excellent foster-mother; of course for best results, I advise most all breeds of Bantams and Japanese Silkies. The most important point in raising pheasants is to rid the setting hen of lice and red mites, which is quite a hard task. Pheasant chicks cannot stand worriment from lice.

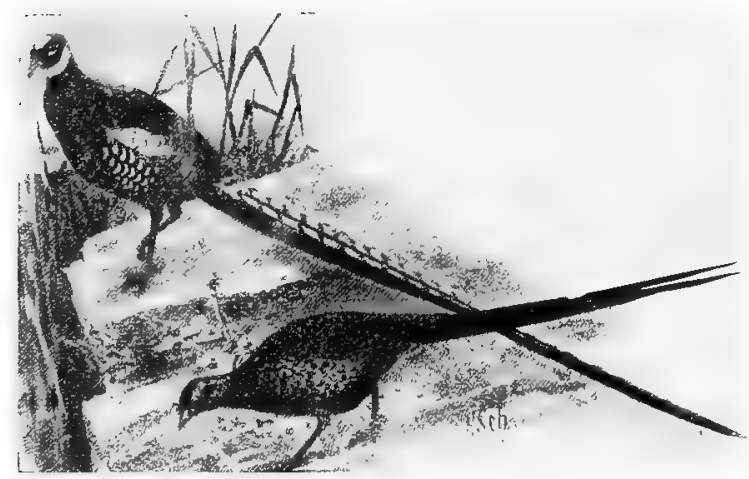

HYBRID PHEASANT -CROSS OF REEVES AND RINGNECK

I believe 50 per cent of all chicks hatched in this country are killed from worriment of lice in their early stages of life. A great many breeders use poisonous insect powder to destroy lice, but I never found it very effective; it does not kill lice eggs and I believe, inasmuch as this powder comes in contact with the young chicks, and gets into their throats, it is very injurious to the birds and a great drawback to their growth. For a number of years I used ordinary kerosene oil exclusively to kill mites and lice on setting hens. Three days before I put the hen on pheasant eggs I give her a few light applications of kerosene oil, rubbing the oil in to the feathers, which does not hurt in the least, and place her on a nest of sawdust treated with kerosene also. I know from experience this treatment will free her entirely from lice and mites. (To keep red mites and lice out, I place sawdust in hens' nests all the year round and sprinkle it occasionally with kerosene.) I remove the hen to a cat-proof yard away from all chicken roosts. I use a common flour barrel like illustration, for a nest, top covered with Paroit Roofing. Nothing beats it. A hole is cut in the side of the barrel for the hen to go in and out at will, the eggs are placed on a piece of sod and the barrel stands in a shady spot in an upright position. In this $I$ come very near to nature hatching pheasant eggs and it has been a great success with me. In extreme dry weather I sprinkle the eggs three or four times during incubation with tepid water. I give a hen from to 10 to 12 eggs, no more, and place as many as fifteen barrels in one yard. To make sure, I place a heavy stone on top of each barrel in order to keep it erect during heavy storms, and in wet weather I place a board in front of hole in a slanting position to keep the rain out. Pheas- 


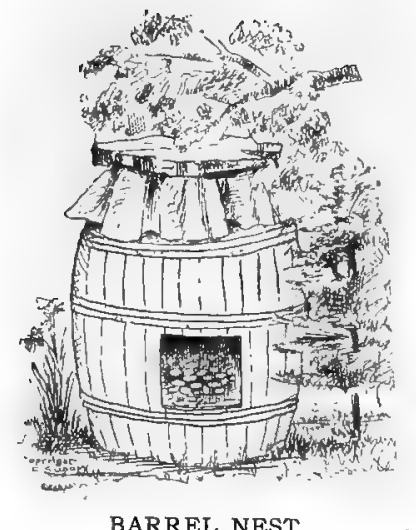

ant eggs hatch within 20 to 23 days. On the nineteenth day of incubation I attach a piece of $1 / 2$-inch mesh poultry wire in front of hole on the barrel so the chicks when hatched cannot jump out and perish. I use a coop like illustration. The entire front is of 2 -inch poultry wire, and place it in a shady spot. The shape of this coop keeps the hen in the middle of the coop and she has little chance to step on the chicks, which is a very important point, as they are very small and apt to get under her feet, therefore I advise small hens for mothers. RUBEROID roofing, best in the world, made by the Standard Paint Co., 100 William St., New York City, covers the coop, which is thoroughly whitewashed and sprinkled with kerosene before using and every week the coop is changed. During wet weather a board two feet square is placed in front of coop, so the rain cannot drive in the coop. A yard about three feet square made of a 12-inch wide board is placed around the coop for the first five days in order for the young to get used to the mother's call and not wander off.

Pheasants, when hatched, are very strong and lively and ready to eat. For the first three weeks I feed canary secd, dry bread, custard, hard boiled eggs, game food and angleworms, and never touched their feed with my hands. Young pheasants should be fed at

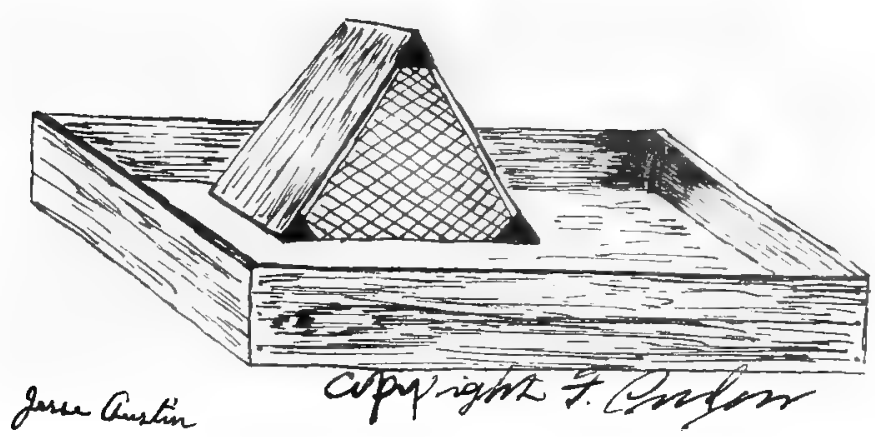

PRACTICAL PHEASANT COOP

least four times a day. I find that custard made of milk and eggs is the best feed that should be given them for the first week. Feed them on a board or common pie pan. Water is given once a day in the evening.

English gamekeepers claim, in regard to first food for the young chicks, there is nothing superior to a supply of fresh ant eggs. For grain, they also strongly recommend a good proportion of canary seed in addition to grit. However, they claim when grain is crushed or bruised its vitality is destroyed and that it undergoes a change, when exposed to the air. The best substitute for ant eggs is custard, made by beating an egg with a tablespoonful of milk and cooking same by gentle heat in an oven. No artificially prepared animal food can surpass this mixture. I am confident that a larger proportion of poults can be reared if custard and canary seed form their food for the first few weeks than on any other diet whatever. 
An excellent pasture is a clover patch or strawberry bed. Grass and greens are as much the staff of pheasants as bread is to man. Young pheasants will thrive on grass and greens exclusively. However, I consider clover the best pasture for them. They are as easy to raise as chickens and can be reared in any kind of climate. 1 raise on an average 80 per cent every year. When four weeks old I feed grain of every description, and when seven weeks old I cage them and give them plenty of perches and lots of brush and old trees to roost on in the run, which is an important point to observe, because young pheasants cannot stand roosting on bare and damp grounds. After October a shed should be provided for pheasants to roost under. Pheasants are small feeders, they grow fast and have their full size and plumage when five months old. I do not approve of giving sick pheasants or chickens very much water, fever appears in most instances with all sickness and keeps the bird drinking constantly, which is very detrimental for their condition. To get pheasants well acclimated and rightly quartered, they should be purchased in the fall of the year.

On many estates in England, pheasants are reared by mating wild cocks to tame hens. The pheasantry is constructed with an open top, and the wild cock birds visit them regularly. They claim that from these birds, the chicks are invariably stronger and hardier and consequently easier reared than those bred in the ordinary way.

A nother plan is to leave the pen quite open at the top and clip one of the wings of each bird, cutting off about fourteen of the flight feathers, close but not into the quills. When the birds cannot fly, they become much tamer, are more productive and not so apt to injure themselves by dashing wildly about. I do not approve of pinioning the birds, as it makes them incapable of taking care of themselves when turned out into the open and certain to fall a prey to ground vermin.

For bringing pheasants home, that have strayed away, I know of nothing equal to boiled potatoes. Boil them with the skins, whole, and cut out of each skin a piece the size of a quarter of a dollar, showing the meat, and place them at moderate distances apart and the birds will follow them anywhere.

In speaking of aviaries. I consider those that are movable, superior to fixed ones so as to enable the shifting to new grounds as often as convenient.

In some parts of Germany, turkey hens are employed to hatch pheasant eggs. These hens make excellent mothers and are capable of hatching and rearing twice the number of poults that an ordinary hen can raise.

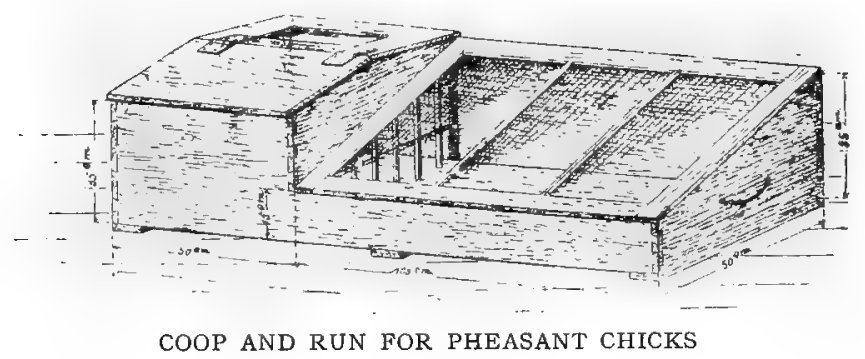

The most practical way of keeping pheasants, and if you have the room, set asidetwo separate runs for a pen of pheasants, and seed these runs in clover in the early spring and change the birds from one to the next run weekly. It will be the means of securing an abundance of eggs and keep the birds in the finest of health. Every breed of pheasants should be kept separate. It is absolutely necessary to have the sun reach the aviary. I visited a pheasantry on Long Island kept by a very rich man. The runs for the beautiful birds were box stalls boarded up four feet and about six feet square. Around these little jalls were attached looking-glasses and the birds were compelled to see their ghosts all day. All I wish to say, dear reader if I had to house in these little stalls I would go crazy within one month. 


\section{Pheasant Breeding Yields an Enormous Profit}

\section{A Fortune to an Industrious Breeder}

(It pays 1,000 per cent better than chicken raising.)

Pheasant meat sells from $\$ 3.00$ to $\$ 20.00$ a pound in the markets.

Pheasant breeding will soon come to the front. The meat far excels any kind of game in delicacy and flavor. It costs no more to raise pheasants than it costs to raise chickens,

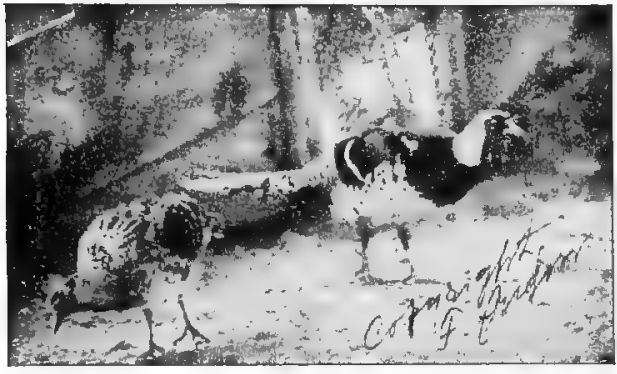

ELLIOTT PHEASANTS in fact not as much, as pheasants are small feeders. Chicken meat sells for 20 cents a pound, pheasant meat sells from $\$ 3.00$ to $\$ 20.00$ a pound in the open market. Again chicken feathers sell for 25 cents a pound. Pheasant feathers sell as high as 30 cents each feather for millinery and fly fishhook purposes. Taxidermists pay as high as $\$ 15.00$ for skins for stuffing and mounting purposes. A fortune can be made in a short period to breed pheasants by the 1,000. A pair of pheasants will yield a yearly profit of from $\$ 40.00$ to $\$ 300.00$. English, Chinese, Ringneck and Mongolian pheasants are bought up in great quantities by our wealthy sportsmen for the purpose of stocking their preserves; also sold in the open market with feathers on in large cities at a high price and in great demand. About 500,000 pheasants are imported annually for the American market, both dead and alive, for table, millinery, taxidermy, etc., purposes. Also for stocking game preserves.

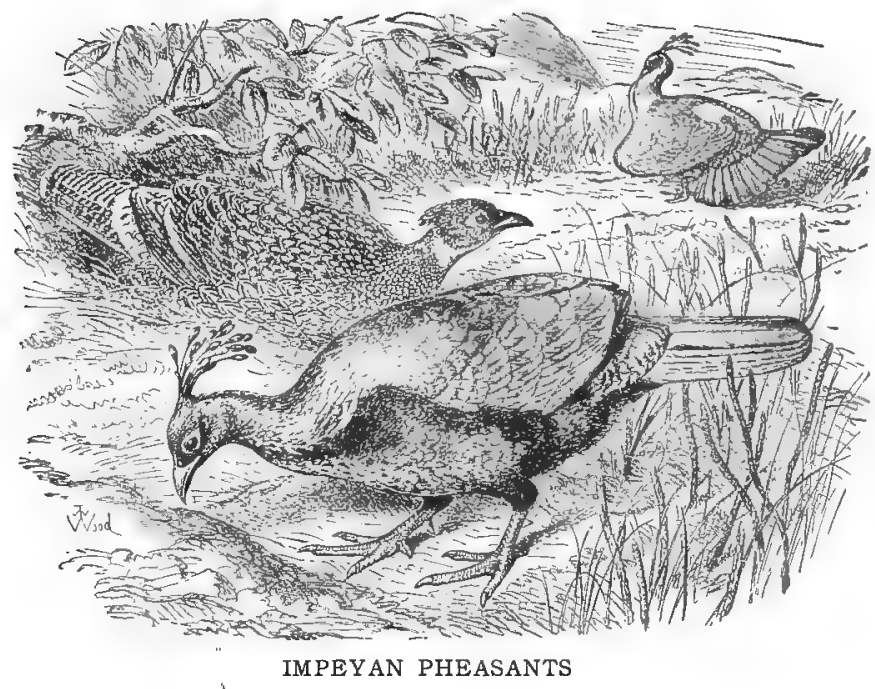

Our wealthy sports are fast following the English Lords for a pheasant invitation shoot of 1,000 birds killed in a day of which we read about frequently in England. Great many gun clubs are leasing small islands along the coast in the east for the purpose of holding pheasant shoots. I furnished to such an island for a private club 800 pheasants just for a day's shoot. 
No doubt they would have repeated this sport had I been able to furnish the birds. Live pigeon shooting is now prohibited by law in the States of New York, Massachusetts, Connecticut, New Jersey, Ohio, Indiana; also quail cannot be trapped or shipped excepting by special permit, and our rich cracksmen are compelled to fall back to some other wing birds. Expense is no object to them; what they want is sport. I am conviriced pheasants for shooting

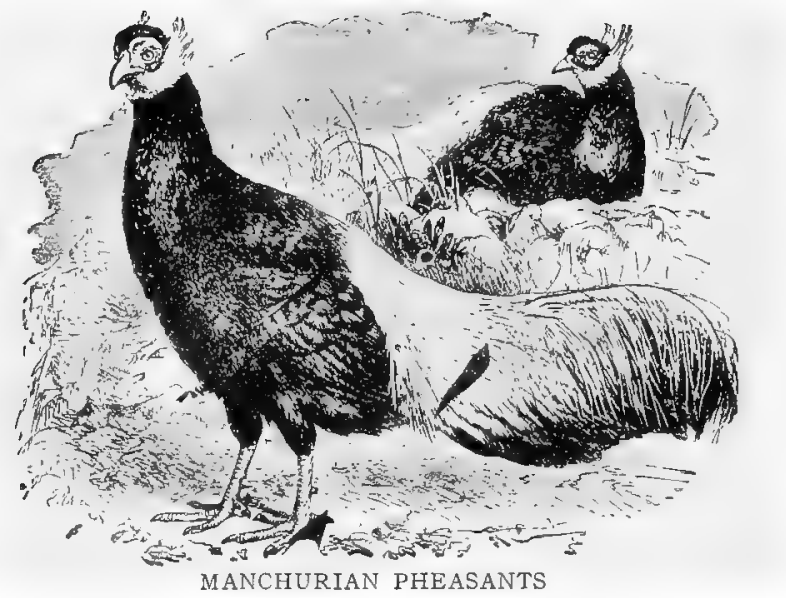

will be more in demand from year to year. I bought every pheasant procurable in thirty States and Canada last fall, which were offered at reasonable prices. Golden Pheasants are valuable for their feathers for fly hook manufacturers, the crest and tipped feathers bring as high as 80 cents a dozen feathers, tail feathers 25 cents each. Golden skins for mounting bring as high as $\$ 800$ each, and there is no handsomer sight than to see a dozen of these birds in a pen. The cost of keeping a pair of golden pheasants is about thirty cents a year.

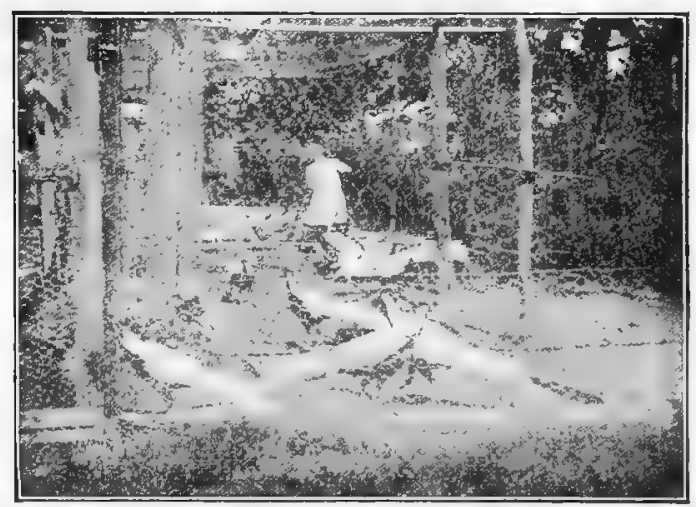

SILVER PHEASANTS

Paint your roosts and coops occasionally with kerosene, in order to keep lice from breeding. According to statistics, lice pests cost the farmers of the country over $\$ 700,000$, 000 .

Make it a point to always keep your tools in the same place, where you can find them readily. 
Amherst, Silver or Reeves pheasants bring as high as $\$ 15.00$ each for mounting purposes, and are in great demand by taxidermists. Beside this market, every variety of pheasants are kept all over the United States as a pet bird. A great many of our wealthy fanciers keep a pheasantry to-day. Howard Gould's plant and collection of pheasants in Port Washington, New York, is said to be worth $\$ 8,000$. The pheasant industry is growing fast. I think I was one of the first pheasant boomers in this country, and have agents all over the world.

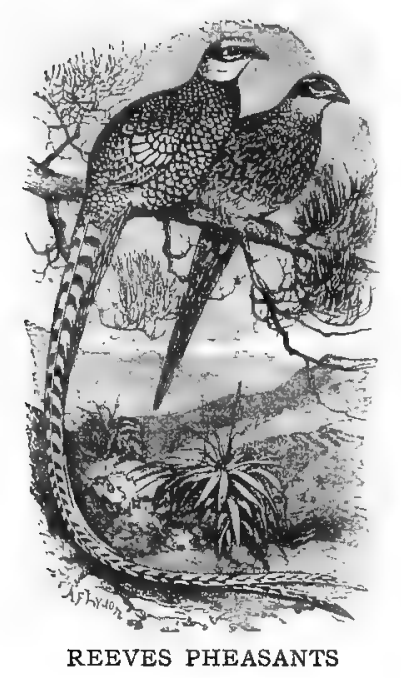

\section{Recipe,for Cold and Roup}

Do not give any water, nor let the bird drink rain water or eat snow. Rub a little vaseline well around the nostrils twice a day for four or five days. To a $5 \mathrm{c}$ jar of vaseline mix about twelve drops of carbolic acid. Feed extra nourishing food.

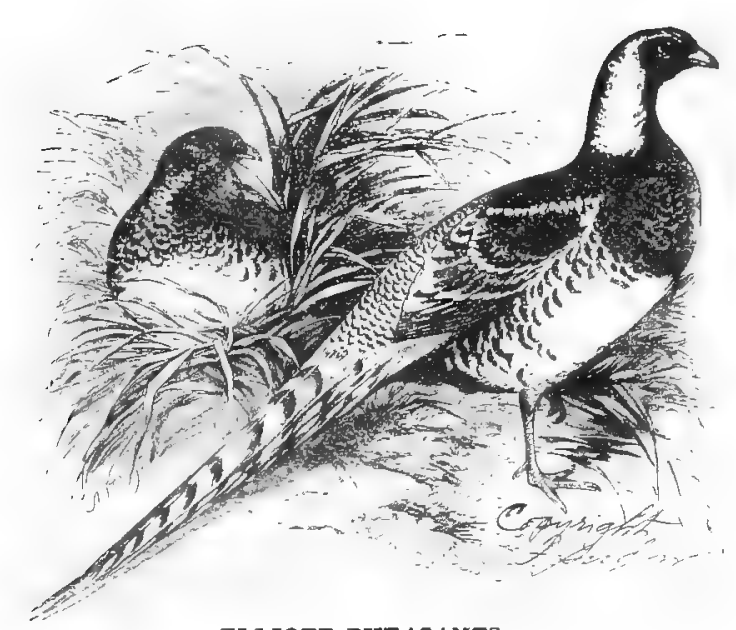

ELLIOTT PHEASANTS 


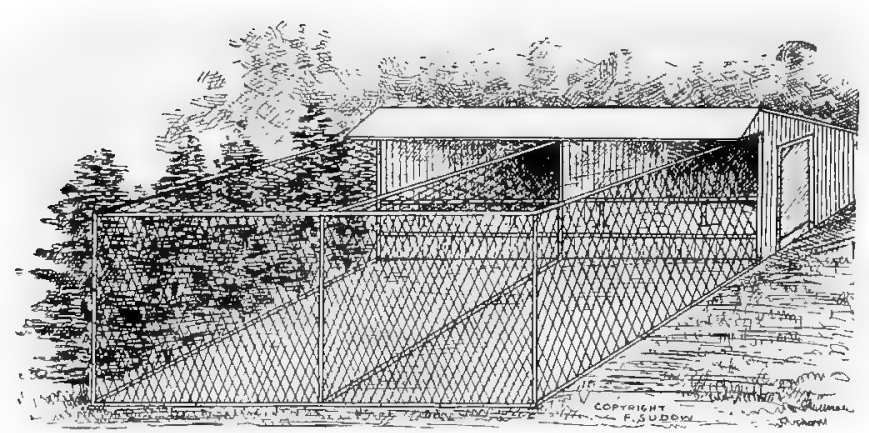

AN IDEAL PHEASANTRY

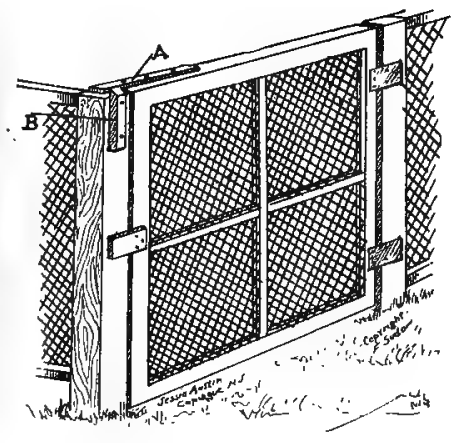

A PRACTICAL POULTRY-YARD GATE

\section{An Ideal Pheasantry}

An aviary built like the above of 1 -inch poultry wire, top covered 8 feet high, 12 feet wide, 15 feet long, with an open shed attached and facing the exposure of the sun with cedar trees on the west side of run in order to break off the cold winds in winter will make about the best pheasant yard I can think of. The perches, made of $1 \times 5$-inch lumber, should be low and in the shed only, in order to compel the pheasants to roost under shelter as they prefer to roost outside. Pheasants fear darkness. They do not like to go under shelter. Their natural inclination is to roost in dead trees. where light is most prominent,

It is practical to enclose the front of shed in 2 -inch poultry wire with a wire door, in order to keep the birds under the shed all together during wet and stormy weather. Fine sand should be put in the shed about six inches deep above the outside surface, answering as a dust bath, which will keep the birds in fine plumage, healthy condition and in order to free themselves of vermin. Hay should be added for the winter. Pheasants can stand any amount of cold weather. The 1-inch mesh wire should be buried six inches in the ground, to prevent dogs, etc., from digging underneath. No boards are used at the bottom. Plenty of shade should be provided for the aviary during the summer. It will be a great pleasure to keep pheasants in an aviary like this. A customer, 72 years old, starting in the pheasant industry, wrote: "I certainly missed a great deal in my life. Every Sunday morning is worth $\$ 25$ to me now watching my beautiful pheasants in the aviary." Pheasants and pigeons go fine together and seem to have a great attachment for one another. Carnegie is trying to make people happy by giving his money away; but as I have no millions to give away, I am trying the very best next thing for your happiness that money can buy. Pheasant breeding will soon become popular, not alone for their beauty, taxidermy and feathers, but meat especially. We all like something good to eat, and there is nothing finer to be had than a pheasant roast.

\section{A Practical Poultry-Yard Gate}

It will make you feel good to open and shut this gate. The greatest obstacle in visiting pheasantries and poultry farms I met with on my trips was to find practical gates for the yards. In some instances it made me disgusted, and again I had a good laugh over it. It took sometimes fully three minutes of hard labor to open and shut a gate. I'd like to hear from the genius who can improve on above gate for simplicity. A is a lath extending 3 inches on the top of gate and which goes behind the block B on the post. This block is set half an inch above the post and made with a slight slant. In using stout leather hinges 


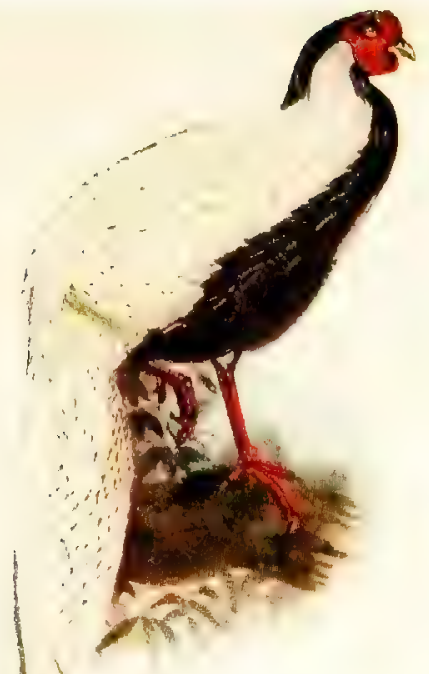

SILVER PHEASANT

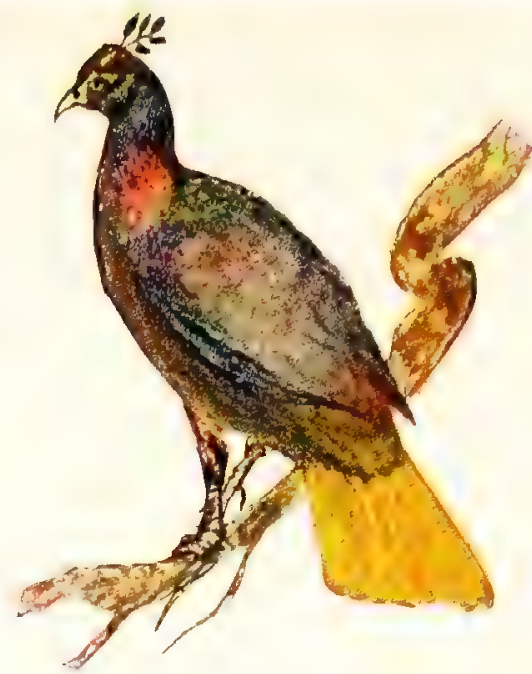

IMPEYAN PHEASANT<smiles>CC1CC2CCC(CC2)C1C</smiles>
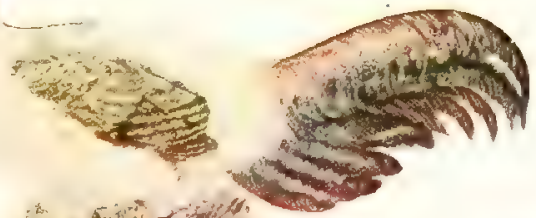

in $x^{2}+y^{2}$

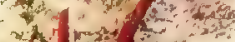

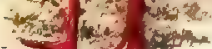

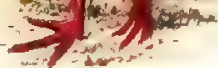

MANCHURIAN PHEASINT

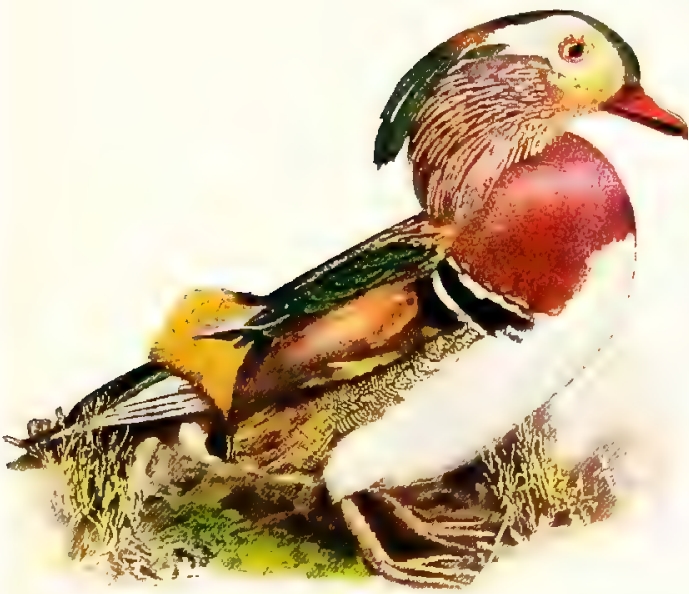

MANDARIN DUCK

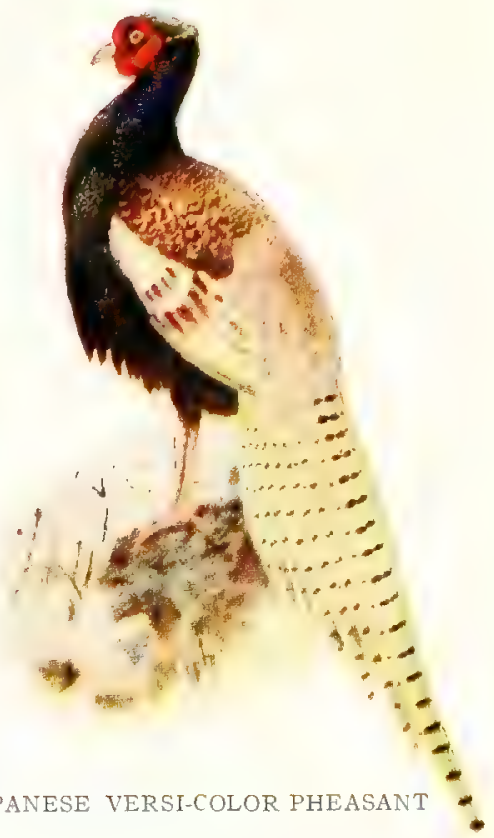





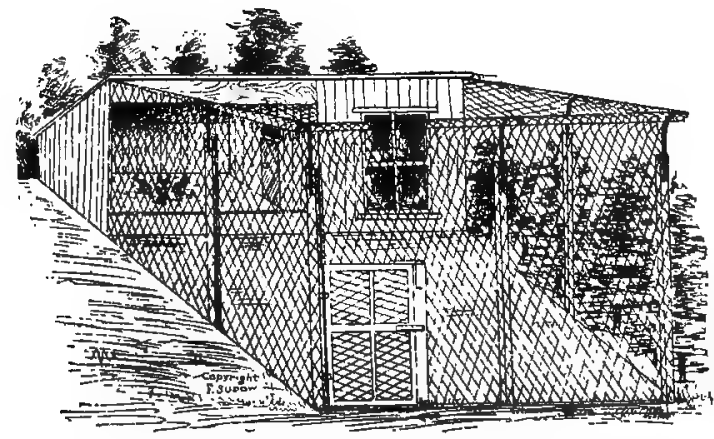

An ideal poultry house and scratching pen with cat-proof yard which is covered with paroid roofing

the gate can be raised off the block (lock) immediately and it will lock and stay locked in giving it a fair slam against the post. It should be hung two inches from the ground. If you cannot comprehend the construction, show the illustration to a carpenter.

If you want eggs all the year around, it is absolutely necessary to have an open scratching pen attached to your hen roost in order to keep the birds working during rough weather Cut cornstalks

are best for the scratching pen. The upper part of half a butter tub nailed to the side of the roost makes a fine hen's nest. Sawdust sprayed with kerosene, placed in these nests is the best preventive of lice and mites. A great many cats eat young chickens, and it is a good idea to have the yard cat proof as explained on another page. Everything depends on how things are fixed practically with poultry. It saves lots of money and an awful lot of trouble and worriment.

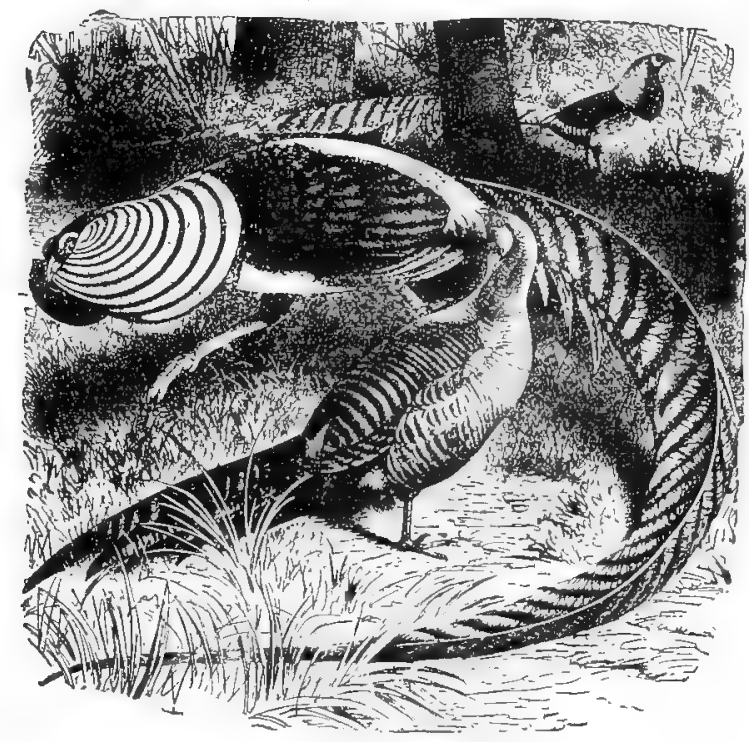

AMHERST PHEASANTS

Displaying their striking plumage during breeding season

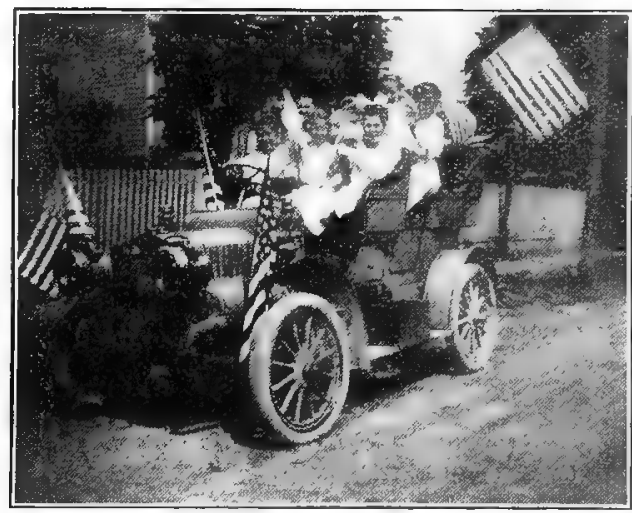

MY FRIENDS, THE CHILDREN, ON A JOYFUL AUTO RIDE 


\section{Cat-Proof Yard and Fence}

Cats are most destructive to young pheasants and I believe eat a good percentage of young chickens. To make a cat-proof yard it requires a fence a cat cannot climb or jump. Set a post $41 / 2$ feet high out of the ground, attack to this post with staples a stout iron rod $21 / 2$ feet above the post, bend over to inside of the yard with a hook on top in order to fasten the poultry wire to this hook. This makes it a 7-foot fence (see illustration of cat-proof fence). Use the 1-inch mesh wire, put it five inches in the ground and attach it to the hook on iron rod. I do not advise using a 2 -inch mesh wire because a small cat can get through this mesh. Cats cannot climb poultry wire, nor the iron rod above the post and

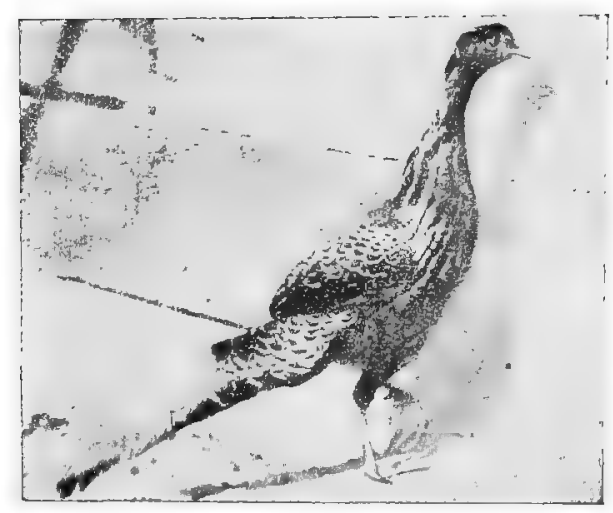

SWINHOE PHEASANT

it is impossible for them to get into this yard. I have tried this cat-proof yard for many years and found it of great success. Before I had the cat-proof yard I always had trouble with cats and my neighbors. On one occasion a neighbor threatened to do me great bodily harm because I shot his pet cat. I told him that his cat had no more right to eat my pheasants than I had in his shop stealing his tools, but he would not look at it in that light and insisted that I committed an act of cruelty to animals because the cat had little ones to nurse.

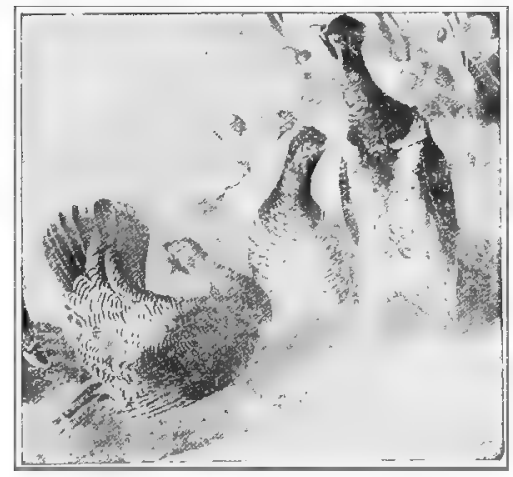

ENGLISH PARTRIDGES

Can be bred in captivity same as pheasants 


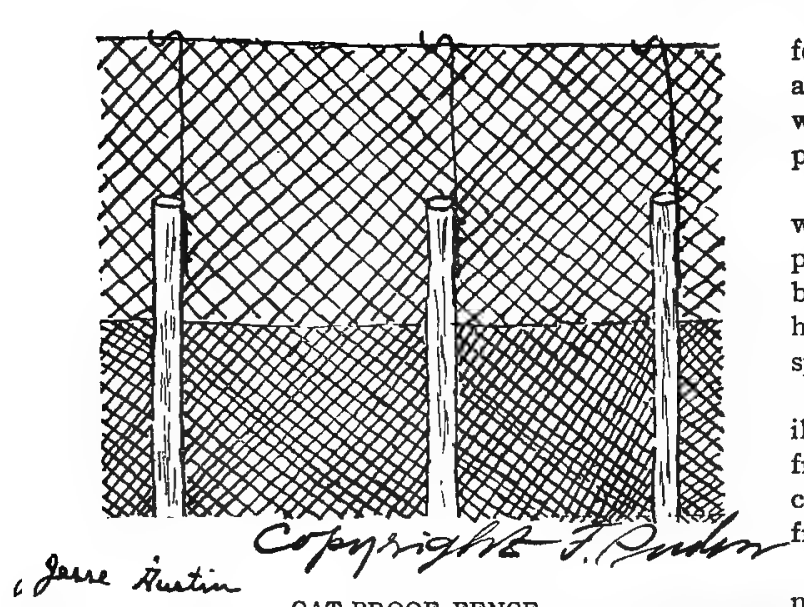

CAT-PROOF FENCE

Cats are very shrewd-more so than foxes-crazy for young pheasant meat, and indeed very hard to destroy. A cat will consume from two to four young pheasants or young chickens in a day.

Placing poison meat is illegal, but where it is absolutely necessary to use poison for cats, a little carbonate of baryta mixed up with a soft roe of red herring or shad, is the most certain and speedy that can be used.

I had three acres fenced in like the illustration and had no further trouble from vermin. Young pheasants and chickens are perfectly safe in this yard from cats, dogs, weasels, minks, foxes, etc.

The illustration below (copyright) shows my original hawk protector for young pheasants, also intended for young chicks

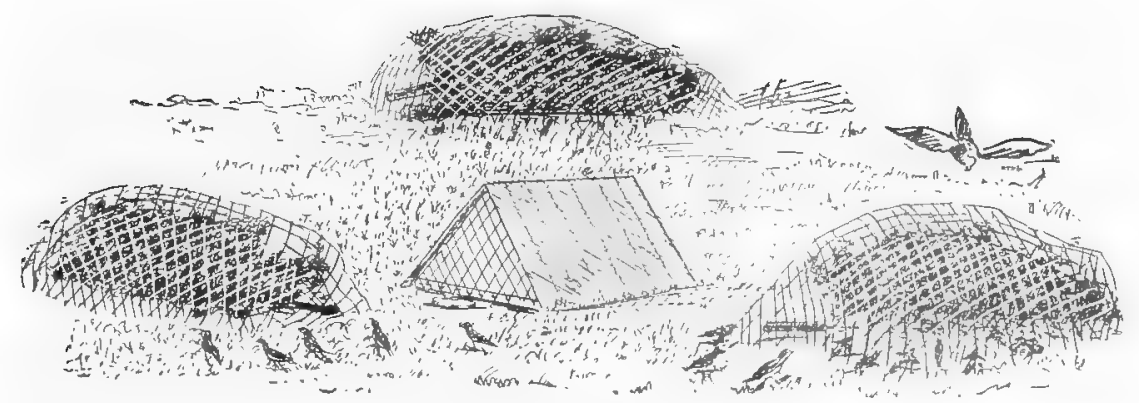

A HAWK PROTECTOR

Around the coop is placed cut cedar trees for the birds to hide in when the hawk makes his appearance Two-inch poultry wire is placed over the cedar bushes and it is astonishing how soon the young birds know these safe places. The hawk, bouncing painfully upon the wire after the pheasants and chicks, and also through the noise of the mother hen in the coop, gets very much frightened; he will quickly retreat and never make his appearance again.

Now dear reader, kindly let me know if you can improve upon this idea. I am trying very hard to stay ahead of foxes. hawks, etc. We have to be wide-awake in order to succeed in this grand industry. And remember, don't "kick," but try and find a remedy for "kicking."

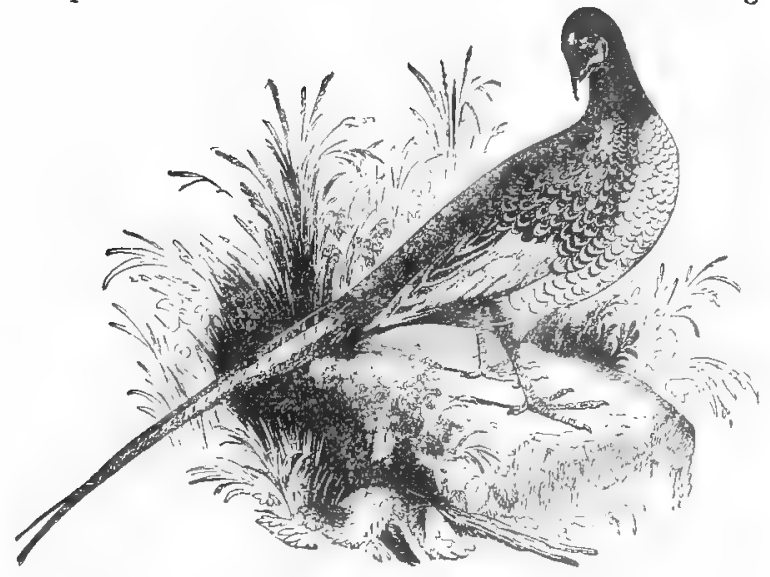

HUNGARIAN PHEASANT 


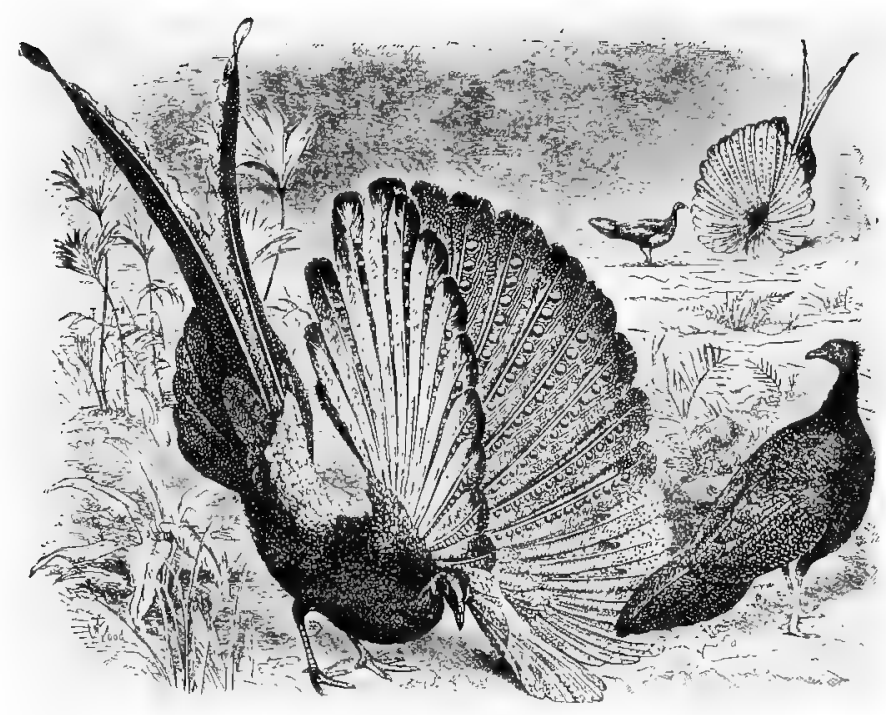

THE ARGUS PHEASANT DISPLAYING ITS PLUMAGE

\section{Shipping Pheasants}

The most practicable shipping coop for pheasants is a wooden box about 15 inches high in which are bored a lot of holes $11 / 4$ inches in diameter in the sides and top. The top holes are very important in order that the expressman may see that the box contains live stock, and not handle the box like a football as they most generally do handle boxes.

I find that the birds keep very peaceable in this coop, peeping out of a hole and inhaling the

fresh air, whereas canvas coops are very hot and the birds are compelled to inhale foul air, which makes them very restless and feverish. The express companies handle wooden coops at single rates, but if canvas is used double rates are charged. We have shipped lots of pheasants to California in wooden coops, arriving in fine condition. Instead of water, potatoes and apples are put in the coop.

Wire or lath coops are the most out of place for shipping pheasants. From all my experience I do not approve of putting water in shipping coops as it is bound to spill out, making the coop dirty and soiling the beautiful plumage of the birds; again. if left for any length of time it becomes stagnant and poisonous to the birds. Pheasants can stand being without water for a week, and does it no harm to the birds.

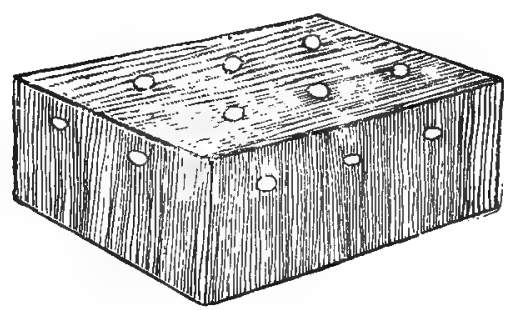

SHIPPING COOP
Paste labels on top of coops, same as the following:

\section{LIVE STOCK}

PLEASE SHIP ON FAST EXPRESS

Dear Mr. Expressman

Please Do Not Handle US Poor Birdies

Like a Football
This is to call the attention of the expressman to the fact that there is live stock in the coop.

Pheasants are shipped to market with feathers on, as they are valuable for millinery purposes.

To properly embark in the pheasant business, it is necessary to be familiar with carpenter's tools.

The Lord will surely reward you if you are good and kind to dumb animals and your enemies.

Remember: On Earth, Peace to men of good-will. 


\section{Pheasant Market}

A game law soon will be established in the State of New York, allowing Ringneck Pheasants to he sold in open market all the year around the same as fowl. Our epicurians want game meat for their tables; the markets do not offer anything in this line. Guineas are offered in restaurants for grouse. These latter birds bring five dollars a pair, shot, in markets, weighing less than a pound and a half each. Shot quail bring ten dollars per dozen, weighing not more than six pounds to a dozen.

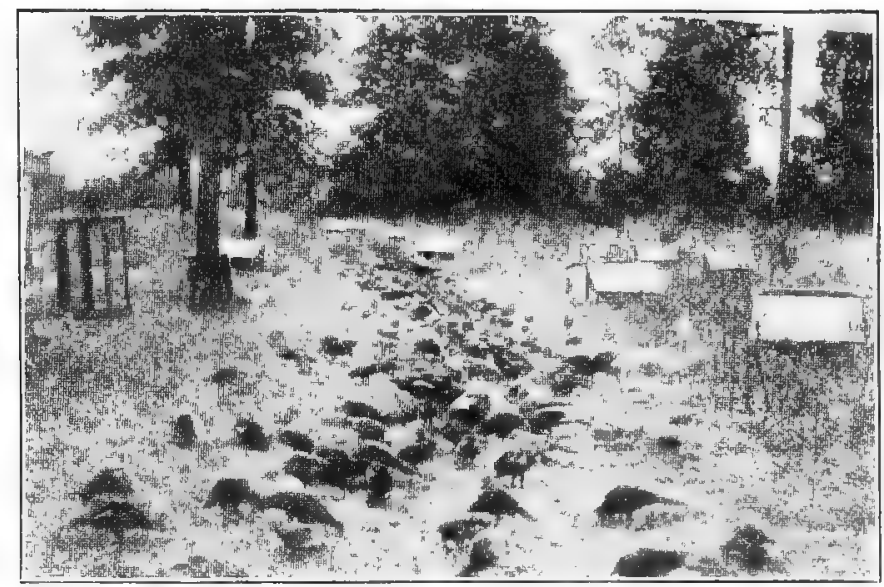

ENGLISH PHEASANT REARING AT THE ILLINOIS GAME FARM

\section{To Keep Pheasants from Straying To Trap Pheasants}

Preventing pheasants from straying from preserves, the use of raisins scattered in their coverts, is particularly advantageous, as they are exceedingly fond of them. So alluring are raisins to pheasants, that they are oftentimes captured by poachers. by means of a fish hook, baited with a raisin and suspended about the height of a running bird from the ground.

\section{Crows the Worst Enemies of Birds}

Rooks and crows are the most destructive birds to pheasants. They will suck the eggs and eat the young. A gamekeeper reported last year that he counted in his preserves, over a hundred empty shells in one day. These rascals should be exterminated and the wholesale destruction begun at once. They are the most bitter enemies of pheasants. The best time for their extermination is during breeding, to kill the young and old at the same time.

\section{A Telegram from California in May}

"Please price pair of Amhersts, that will nest this season."

Now, dear reader it is a well-known fact in changing domestic fowl to new quarters, stops their laying about two weeks. A pair of pheasants sent from New York to California in May, changing climate and quarters, I am positive will hardly breed that season at all. I advise to get the birds as early as possible in the season to insure breeding with them as cer. tainty. 


\section{For Sportsmen Nothing Exceeds Pheasant Shooting}

There is no sport in Great Britain to compare with pheasant shooting. This is the general opinion of the English sportsman, and as the pheasant has many natural enemies besides man, it is more preserved and protected than other game.

Pheasants are bred in large numbers in Europe and thousands are shot yearly on the preserves and many are sold in the open market like poultry, and in my opinion this policy should be followed in this country.

Many successful gamekeepers do not give water at all, others only in a very small quantities One of my correspondents writes: "I know a keeper who rears a great number of pheasants each year and he does not give them water until they are seven or eight weeks old, at which age they begin to eat grain and require water to aid digestion. He claims that pheasants in their wild state take the dew in the morning, and only in very dry weather do the old hens take their brood to water. In very dry weather when there is little or no dew. he sprinkles water twice a day on the grass. However. when he waters the hens, he does not allow the poults to drink." I endorse the great value of lettuce as food for pheasants.

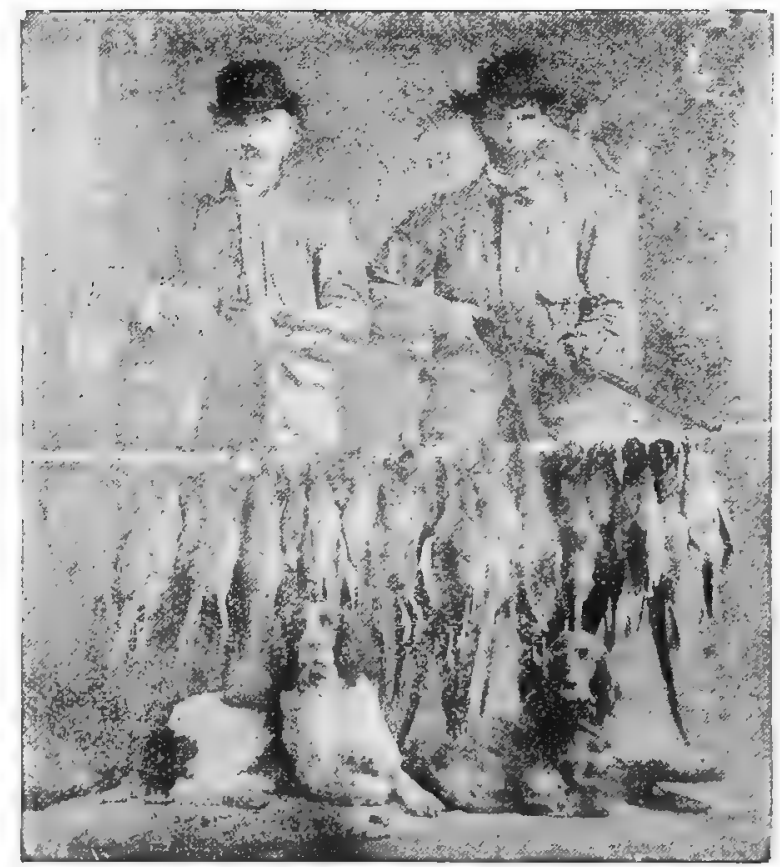

A MORNING PHEASANT SHOOT IN OREGON

\section{Pheasants as Insect Destroyers}

The pheasant in its wild state, is a friend to the farmer as its food consists largely of insects and their larvæ, worms, grasshoppers, etc.. as well as the roots of many weeds. As an insect destroyer they are unsurpassed. They are the inveterate foe of the very vermin which causes so much loss to the horticulturist and grain grower. They feed on caterpillars. field mice and scores of other pests infesting orchards, cotton, sugar-beet fields, etc. 


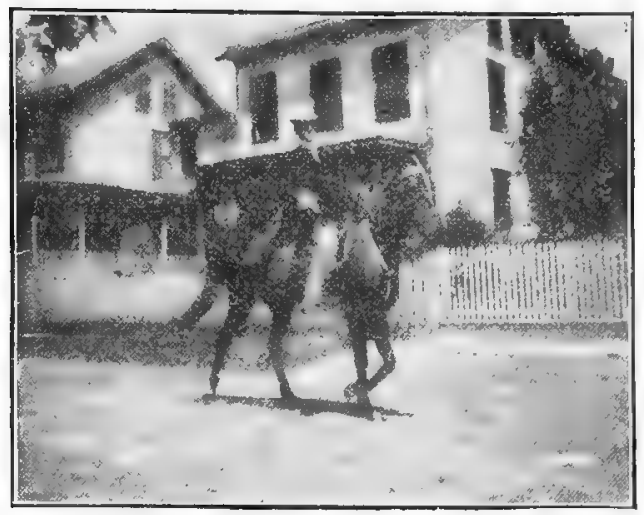

Ferd. Sudow (the man who uses a gold bit and golden spurs) on his beautiful Saddler "Jack"

Horseback riding, the noblest and finest exercise on earth. It is the out-door exercise which is most beneficial to man kind, strengthening, preserving and lengthening life.

Sweet Home;" Olga Nethersole in "Carmen." the world, none affording me such pleasure as to look at the never-tiring beautiful pheasants, the most beautiful birds in the world and which become more beautiful every year.

According to Tegetmeier's collection there are 24 distinct varieties of pheasants in this world. Some varieties will cross with each other and again produce very handsome specimens, especially the cross of the golden and amherst pheasant. I have been looking for points in breeding pheasants the past 12 years and have visited many places where pheasants are raised successfully. Ten years ago I would have gladly paid $\$ 100$ for these instructions, most of which I had to learn from my own observations. I think, dear reader, I have in brief made every effort to explain the principal points of the care, protection

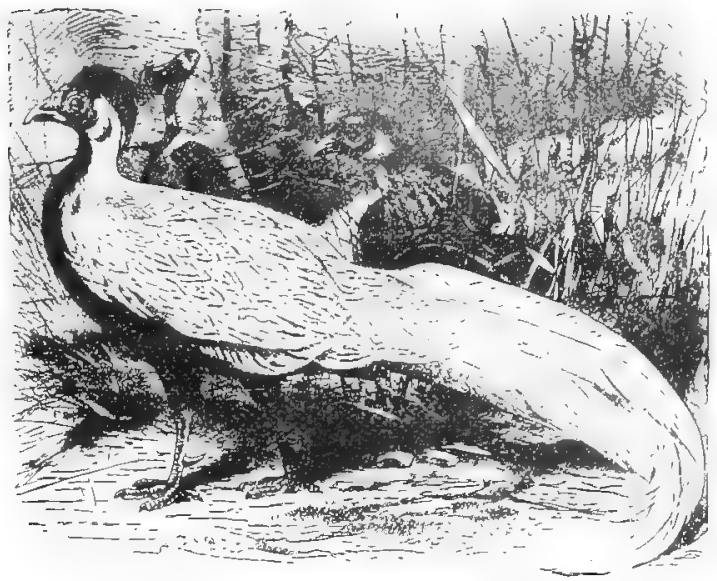

and raising of pheasants, and it will answer for chickens also. If I filled another fifty pages with so much classic and comic operatic poultry talk I conscientiously believe I could not give any more beneficial knowledge.

If you follow these directions I am convinced you will be successful raising pheasants, but if you think any old thing good enough to raise these birds, you will soon give up in disgust. Natural color plates of all varieties of pheasants almost life-size can be bought for 30 cents each.

Let us all join the regular army for Parcels Post, for better, quicker and cheaper transpor. tation service.

Advocate Parcels Post and help regulate Congress in this much-needed movement. 
The State of Illinois has the distinction of possessing the most progressive Game Commission. It receives an annual revenue of over $\$ 100,000$ from gun license and this money is being appropriated for the propagation and stocking of game birds. In the neighborhood of 25,000 young pheasants were raised last year on the Illinois State Game Farm and planted all over the State. The Game Commission states that pheasants have proved a great success and the birds are given every protection. Private preserves are also inaugurated in various sections to promote the propagation of pheasants.

\section{How to Attract Birds}

Much may be done with very little trouble to induce species of wild birds to come about the house. A short observation is sufficient to demonstrate the facts relative to what birds really require if they are to stay about you.

The conditions plainly necessary are: First, food; second, reasonable security from enemies; third, suitable nesting places. Much food may be provided about a farm by simply letting Nature have her own way to a certain degree. Do not cut down all wild cherry trees; leave a few for the birds. Let some blackberries grow here and there. Plant a few sunflowers in the corner of the garden or along the edge of the field. They will take up little space and yield abundant food for the chickadee, goldfinch, titmouse, nuthatch, cardinal and others. In winter a little beef or sheep fat tied to a tree will be deeply appreciated by the downy woodpecker and titmouse. A little broken refuse grain and chaff in winter will likewise furnish comfort to the snowbirds and various native birds, if it is thrown out where they can get it.

Birds do not care to remain long about a house if there is grave danger from enemies. The most terrible of all destructive agencies to the average farmland bird is the domestic cat. This creature pounces with great frequency on the birds when they arefeeding or hopping along the ground; it catches innumerable young shortly after they have left the nest and are as yet unable to fly; it eats the little ones in the nest or catches the old one as she broods at night.

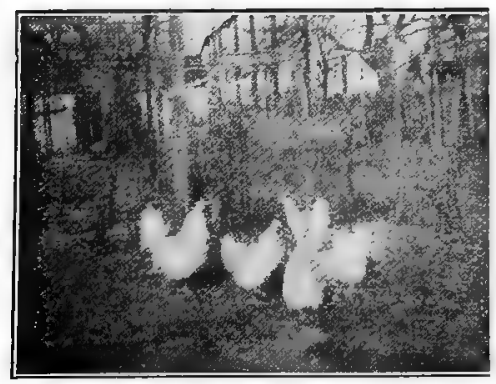

Japanese Silkies, excellent foster mothers for Pheasants and Mandarin Ducks. Extremely tame and genteel, very pretty and fine winter layers; do not scratch.

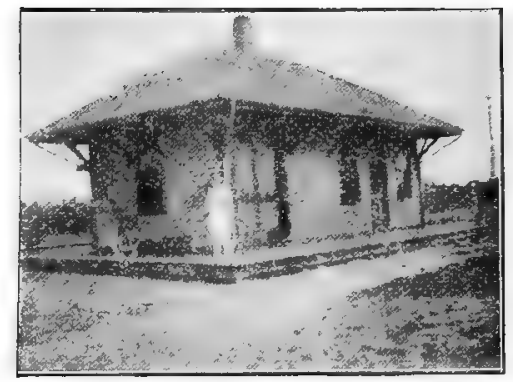

This is the author's picture at the Station, Copiague, $N$. Y., where he had his first Pheasantry and from which station he made a great many shipments of Pheasants.

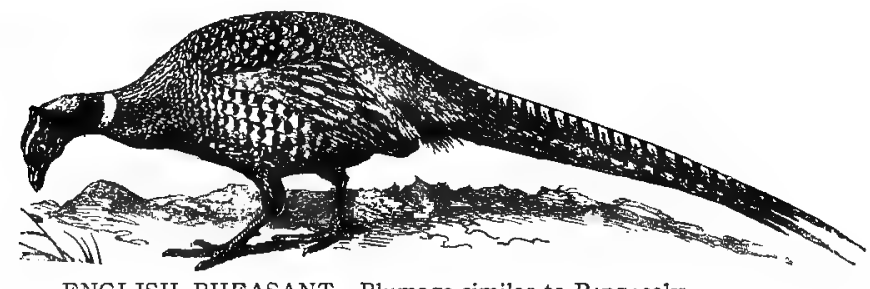

ENGLISH PHEASANT-Plumage similar to Ringnecks 


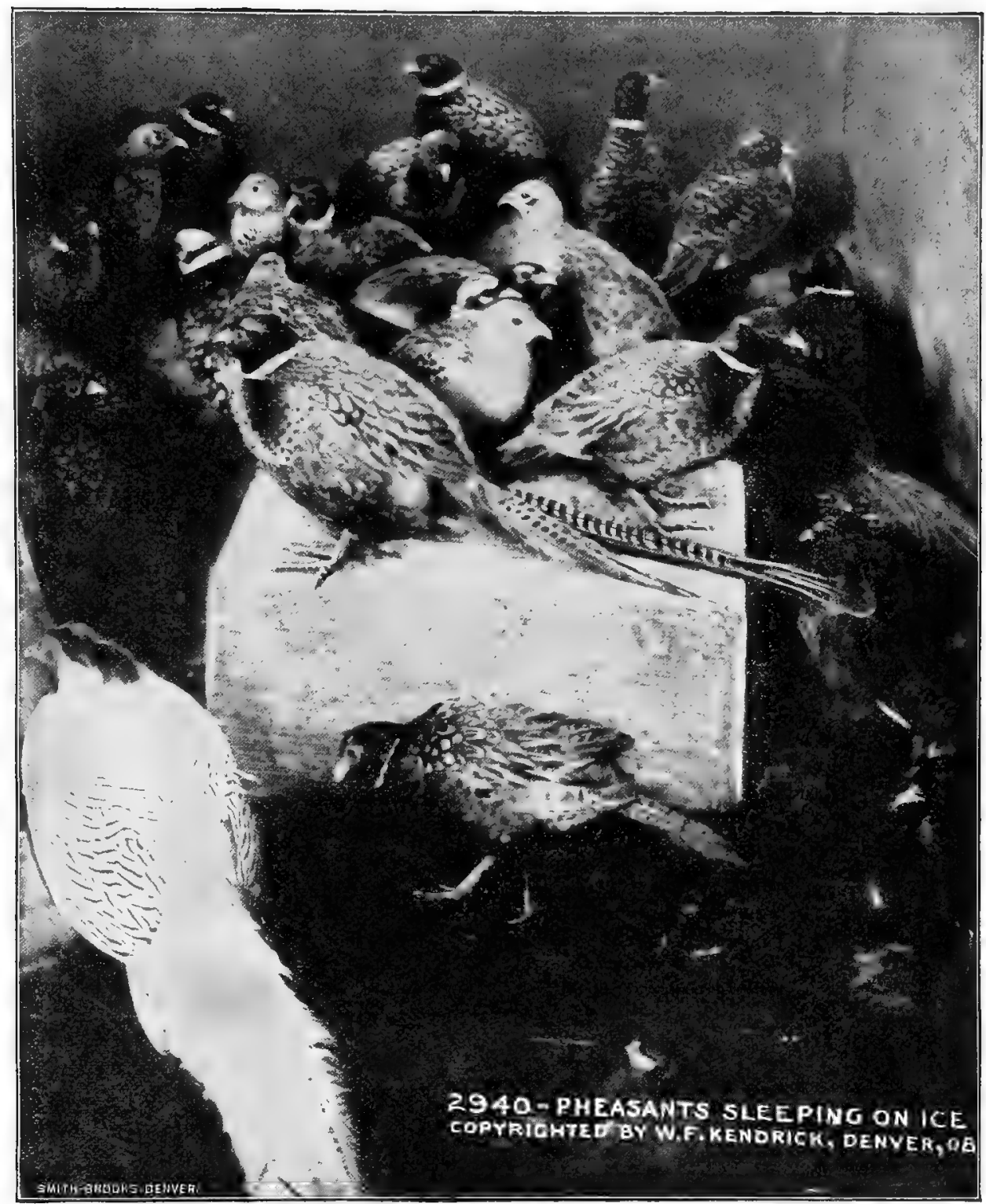

The group of Chinese and English Ringnecks, Silver, Reeves, Goldens and some other varieties of pheasants from the pheasantries of W. F. Kendrick, of Denver, photographed while roosting at night on big cakes of ice during the month of January is a decided novelty. The preparation for flashlight disturbed them somewhat and a few slipped off, but they sleep night after night on the ice or snow, or on heaps of brush in preference to what human beings would consider more comfortable quarters of perches under shed enclosures, showing that the birds are hardy and can live and enjoy life in the midst of snow and cold, as readily as in the warmer climes. 
This flashlight was made for Mr. Kendrick to illustrate practically and convincingly by ocular demonstration the hardiness of the different varieties of pheasants on constant exhibition at Denver's City Park, forming one of the largest and most gorgeous collection of pheasants in a public park in the world.

Pheasants are very active and on the move all day long, therefore I advise loosening the soil in the yards occasionally to prevent their feet from becoming sore and calloused.

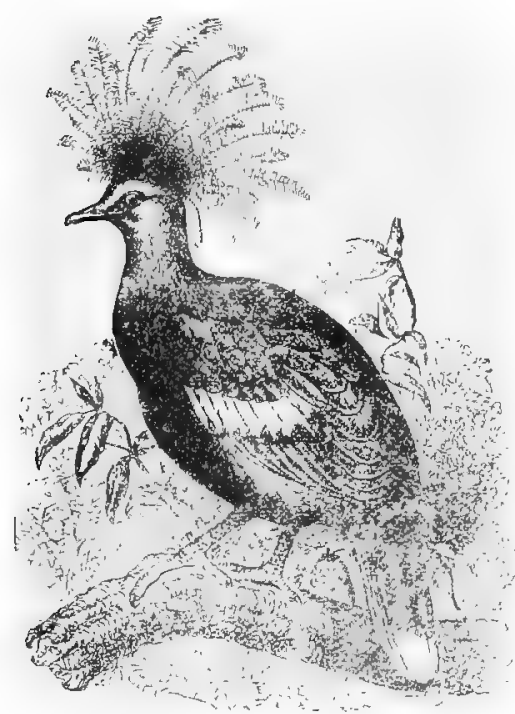

AUSTRALIAN CROWNED PIGEON

\section{Australian Crowned Pigeons}

The members of this family are the largest ex1sting pigeons; their size is about the same as the pearl Guinea fowl and are characterized by the erect fan-shaped crest, which adorns the head and have the metatarus covered all over with six-sided scales; the general color of the plumage is light bluish slate. They are very tame and a great ornament in any aviary. They will breed in captivity same as common pigeons, the hen laying two eggs-but only once a year-they are extremely rare birds.

When you build a poultry house be sure and tack wire in front and back or windows to prevent the birds from breaking the panels of glass and injuring themselves. Hay or straw or other material in the scratching pen should be changed every month. Chickens and pheasant coops should be filled with fine soft sand at least six inches above the outside ground in the winter time, giving the birds a chance to dust themselves.

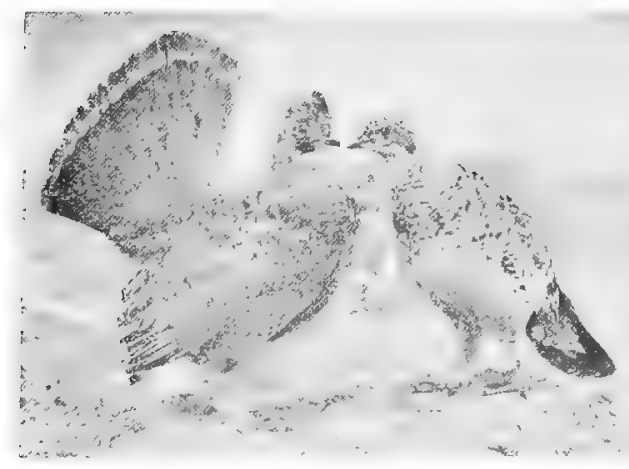

SCOTCH GROUSE

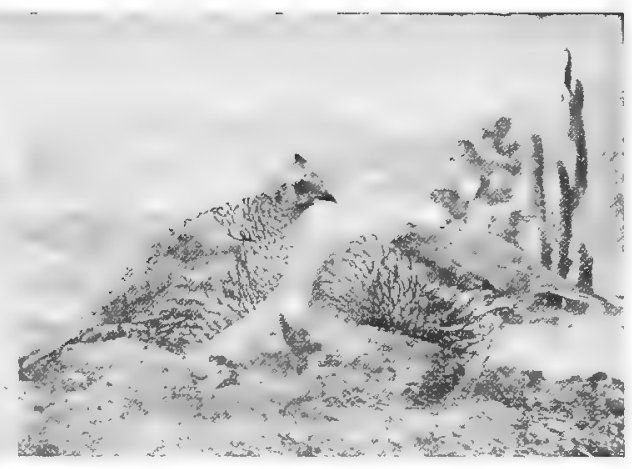

SCALED PARTRIDGE

All these birds can be raised in captivity same as pheasants

City Man:- "When a hen is broody, is she sitting or setting ?"

Hiram Agin:- "I don't care a goll-durn whether she's sittin' or settin', but when she cackles l'd like to know if she's layin' or lyin'." 


\section{Notes From Another Pheasant Fancier}

Gorgeous plumage of many hues to delight the eye, high prices to fatten the purse, choice dainties for the table. These are three of the concomitants of pheasant farming.

Few persons in the United States have discovered or taken advantage of the opportunities for enjoyment and profit afforded by breeding the little multi-colored game bird that originated in the wooded dells of China. Nevertheless, there are more dollars to be acquired from a pheasant farm than from probably 99 per cent of the so-called gold mines. There is more money in pheasants than in chickens and that at the expenditure of far less labor and care.

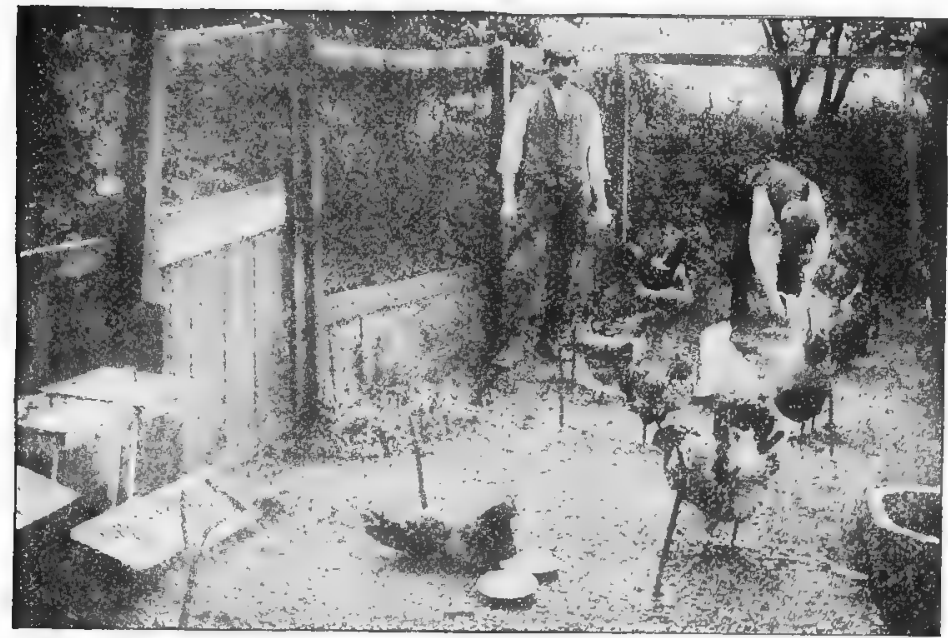

A MORNING PARADE OF SETTING HENS OUT FOR AN AIRING.

Chickens sell for 25 to 50 cents apiece, pheasants for $\$ 5$ to $\$ 25$ a pair. Is not that suffi cient to attract the hustling, progressive American to a new industry? If more be needed, let him consider how beautiful is the pheasant, how the epicure rakes the 'markets with a fine tooth comb till he finds its toothsome flesh, how the sportsman thrills with pleasure as he harries woodland or meadow, gun in hand, for a shot at this most timid creature.

Long the game bird of England, where it is hunted and bagged as the choicest sport of royalty, the pheasant is destined to take the place of the prairie chicken, the quail and the partridge all of which are fast becoming extinct in the game preserves of America. How soon? That is a question any man, woman, boy or girl may help answer. And in working out the problem everyone who participates intelligently may enjoy both pleasure and profit from the successive steps of the solution.

Broadly speaking, there are two classes of pheasants, one suited for the aviary and known as "fancy" breeds, and the other adapted to wild life on the game preserve. Of the latter, the English and Chinese ringnecked are perhaps the only varieties worthy of consideration by Americans. Of the former, there are numerous kinds and the rarer the variety, other things being equal, the greater the profit in raising them. For such birds there is a practically unlimited market, commissioners of public parks in cities and the aviaries of the wealthy, who maintain summer homes and fancy farms, being constantly in need of handsome show or breeding birds.

Never catch a pheasant by one leg as you would a chicken. Their legs are easily broken. The best way is to have a crotched stick, similar to the boys' slingshot prongs, only larger. Stretch string netting between the forks and lower this on the bird pressing it firmly to the ground. Then catch it with a hand on each side pressing the wings 
Aside from the sale of the pheasants themselves, either as show birds, as breeders for aviaries and game preserves, or for consumption on the table, a big profit may be realized from the eggs and feathers. In this connection there is food for the thought of those humanitarians who are interested in the preservation of the pretty, wild birds that sing in or ornament the gloves and forests of the United States. Women's hats must be decorated, and to supply this adornment the songster will be sacrificed until a satisfactory substitute for his plumage is placed in the hands of the milliners. The pheasant is just the bird to furnish this
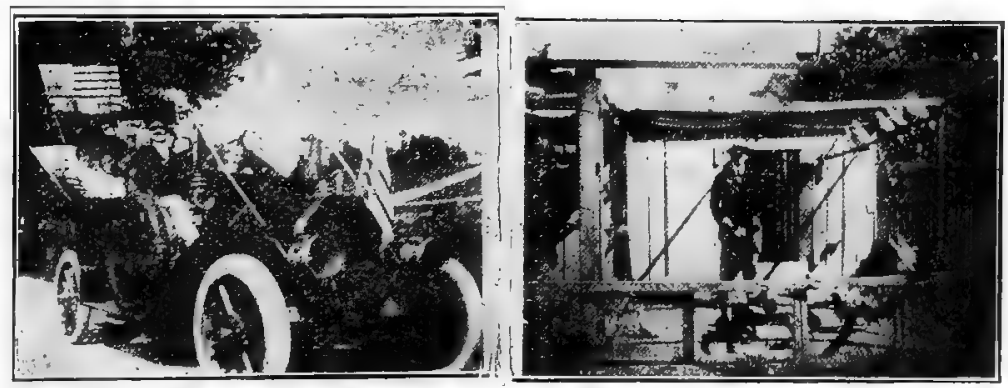

AUTOMOBILING AND RECREATION WITH THE BIRDS-A happy pastime and a fine physician

substıtute, and has furnished it for some time in limited quantities ' with greater propagation of the pheasant the songster may be saved from the despoiler.

For example, take the English ringnecked pheasant. The plumage of the cock is surpassingly beautiful. Its colors are rich and changeable. The brilliant colors of the breast shade from a deep red to violet, green and bronze. A single breast will make a band several inches wide and two feet long. What could be more ornate than such a breast daintily set on a woman's hat?

The head of the English ringneck is green, blue and violet, with a white ring around the neck. On each side of the head are bright red wattles which the bird expands when excited. and then they look like beautiful fans. All these feathers, together with the tippet, breast saddle and centre tail feathers, have a commercial value. The milliners eagerly snap them up, and what the milliners don't want the manufacturer of fishing flies grab at, for they are especially valuable in putting the finishing touches on fishing tackle.

\section{Pheasants the Friend of the Farmer}

Upwards of 1,200 wire worms have been taken from the crop of one pheasant, to show how much they consume. The total insects destroyed must be incredible. From the crop of one pheasant 450 grubs of the crane fly or daddy-long-legs were taken. Those long-leg insects being very destructive to roots of grass, grains, vegetables, etc.

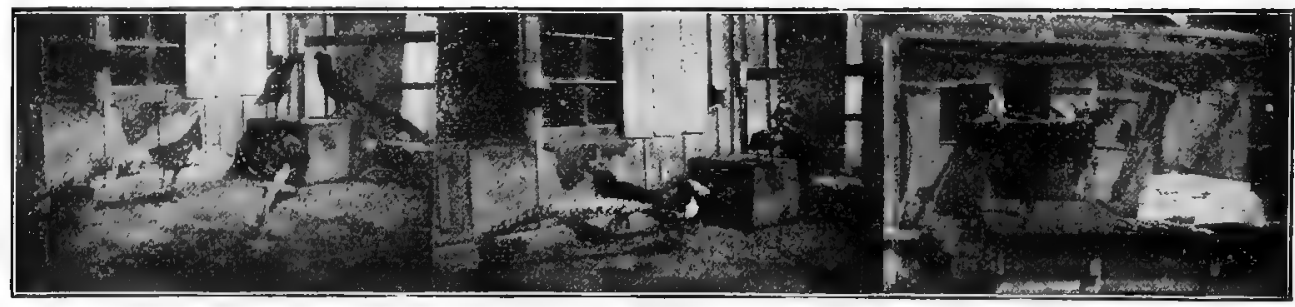




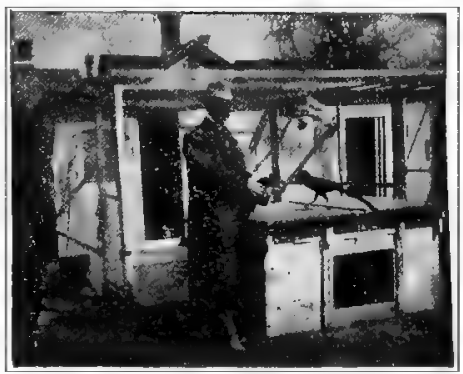

F. Sudow displaying his magnificent tame Golden Pheasant Cock in the open Garden

The male of the golden variety of pheasants and of the Chinese ringneck is even more beautiful than the English ringneck, which is a cross between the Chinese and the English pheasant. The Lady Amherst is considered by many the handsomest of all the pheasant family. His crest is black, with a few red feathers; his face is a pale green; his tippet white, edged with green and barred with black; his back orange red. The two centre feathers of his tail are very long, of gray color and barred with black.

Could anything be more picturesque than a green lawn dotted with such birds? Their rich coats blazing as they stand in the open, reflecting the sunlight, or as they dart hither and thither among the shrubbery, make a panorama of the landscape and add a domesticity to the scene that is otherwise unobtainable. That is one reason why they are so much in demand by the owners of "country estates" and summer homes. Always clean, dainty to a degree, graceful in shape and movement, timid, but tame when they learn their grounds and masters, not noisy, they fill a place no other fowl can fill.

The hens, though handsome, do not wear the splendid colors that distinguish the justly famous cocks. The hen of the golden pheasant, for instance, is of a rich brown color penciled with black. Her breast has a slightly yellow color and her legs are bright yellow. Apparently her pride is centered in her lord and master, and he is ever displaying his wonderful wardrobe for her inspection. Except in the molting period, the cock is always a lively wooer. He dances about from morning till night. He displays his tippet first on one side, then on the other. He stands on his perch, drops his wings, and spreads the gold feathers on his back, revealing steel-blue wing coverts, green shoulders and dazzling red breast. Then he whistles a clear, sweet song, or spreads out his gorgeous tail with a graceful sweep, a wonderful tail twenty-five of twenty-seven inches long, of brown color interspersed with black spots.

\section{Millions of Chickens are Killed Every Year by Rats}

Statistics say, rats are damaging this country about $\$ 30,000,000$ a year. Every farmer suffers from rats. Half of his chicken crops are killed by rats. The below trap is constructed of the following: build a box 4 by 6 feet and line the inside walls with tin and the floor with $1 / 2$-inch poultry wire. Leave an opening on one side about $31 / 2$ inches square, To this opening build a tube or tunnel (a passway, funnel shape) two feet long, the opening on the end of this tube to be large enough to admit a rat. This tube to be made of wood and to be easily removed at intervals. Now place food in this trap for a week or so in order to coax the rat and get her accustomed to the place after which attach the tube. The rat will enter the trap through this tube. As many as 40 rats have been caught in this trap in one night. To be sure tack tin on the outside of the tube, also at the end of the tube around the mouth, giving the rat no chance to crawl back into the tube. Set the tube in an angle so it will be about two ft. from the floor at the end. An excellent idea is to have decoy rat in the trap. This trap will answer to place poison for rats and for other animals of pry also. To poison rats use strychnine. Dissolve a half ounce of strychnine in a pint of water, add a pint of thick sugar or syrup and stir thoroughly. In preparing the bait it is necessary to moisten the food with the syrup. Whole grain should be soaked over night in this syrup. The best bait for rats is food of a kind which the rat

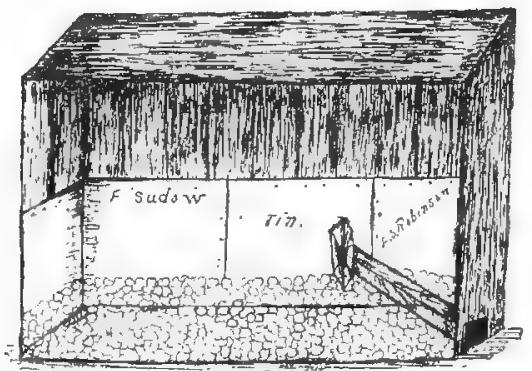

A PRACTICAL RAT TRAP does not get on your premises. In constructing rat-proof wooden floors drive a lot of spikes through the floor to project the other side. 
Of all the family the Argus and the Reeves pheasants are the largest. The male of the Reeves variety is prized above all others for his length of tail, the feathers often measuring fifty-six inches; the edges of the feathers are chestnut brown, the centre pale gray with semicircular bars of black. The bird expands his tail into a gigantic fan whenever excited. The hen of the Reeves variety wears a coat of rich brown of several shades. The cock has a white head, in every feather of which there is a black dot. Below the crown there is a jet black band. The neck is white, the breast jet black. The back feathers are of gold, edged with black, and the wing coverts are black and gold. The eyes are red, with a white streak underneath each.

Pheasant raising either for pleasure or for the money there is in it is an industry especially suited to women and professional men who want recreation without idleness. : The pheasant is a hardy bird. It thrives in the coldest climate. It requires comparatively little care. Dryness of quarters, however, is an essential to the greatest success This fastidious denizen
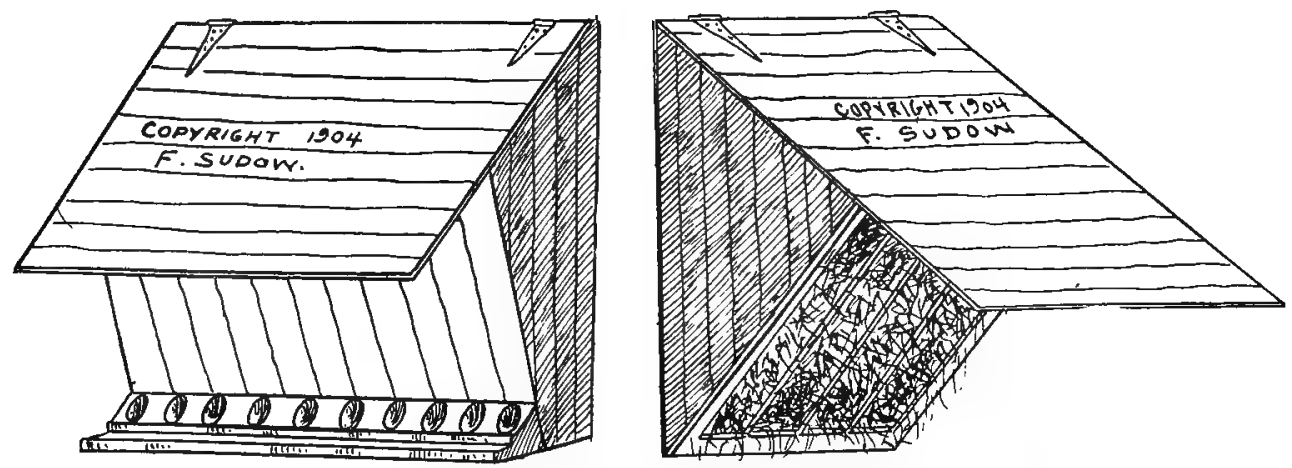

FEEDER AND MANGER FOR BIRDS

of the aviary cannot stand dampness underfoot. He has no fear of frost. but often roosts outdoors when it is 10 to 20 degrees below zero without showing any ill effects of exposure. $\mathrm{He}$ sits on a perch through a night of sleet and snowstorm and holds his own though frost and snow gather an inch thick on his back while he is outdoors, but he must not be compelled to strut inside on water-soaked earth or damp floor.

Requiring very little or much space, according to the condition of the keeper, pheasants can be raised in cramped backyards of cities, in the more spacious lots about residences in small towns or on the broad acres of the farmer. From a very small beginning large results grow. One woman in Chicago who raises pheasants as a means to occupy her spare time, realizes $\$ 200$ to $\$ 300$ a year from a single trio of golden pheasants, and she says this is only an average obtained from her large pheasantry. The same woman sold thirty-six eggs and set twenty as the product of one trio of birds in a single season. Nineteen of the twenty hatched and she raised to maturity seventeen of the chicks. She sold thirteen of the seventeen for $\$ 76$. More than that. she didn't have to hunt for customers; they hunted for her.

\section{An Aid for Indigestion}

The best exercise for stimulating a torpid liver is to sit astride a chair facing the back, holding the chair firmly in order not to move in the seat. Now twist the body one way around and then the other as far as possible. It gives a stretch on all cords and muscles in that region which is very beneficial to the liver. This exercise to be taken at least five minutes, night and morning. Try it and you will feel better. 
Another large pheasant farmer we find in Illinois. He began raising pheasants when he was nine. He started with three birds that, he was forced to keep in an aviary twelve feet square in the backyard of his family home. Within ten years this boy has built up the larg-

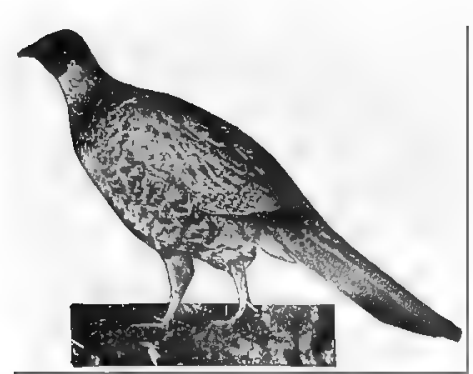

HYBRID GAME BIRD OF ENGLISH PHEASANT AND PARTRIDGE est single pheasantry in the world. In the breeding season he has from 4,000 to 5,000 birds on his great preserve, situated within twelve miles of the very heart of Chicago. His father raised pheasants in Wales; thus the boy had a natural instructor when he took up the industry at the age of nine. This young man studied and talked pheasants, attended his flocks and from his insignificant start has become independent, with thousands of dollars now invested in his farm.

The person who wishes to raise pheasants should select, if possible, a lot that slopes to the south, though this is not a necessity. Build a shed of matched boards on the northern end of the lot, the shed facing south. The front may be partly boarded up or left open. The roof should slope from the front to the back and must be rain-proof. In front of the shed construct an outdoor runway as large as convenient, say twelve by fifteen feet, of wire netting. This netting should be of one-inch or less, but not under three-quarters of an inch. The netting around the inclosure should be sunk into the ground about ten or twelve inches, to prevent rats or other enemies of the birds from burrowing in and killing the fowls. Over the top of the runway there should be wire netting, so as to make sure of the confinement of the pheasants

Cedar trees or grapevines may be planted on the west exposure of the runway to break the heat of the sun in summer and the strong winds of winter. Shrubbery and grass may be grown inside the runway, affording coverts for the pheasants to hide under and green food for them to pick. Inside the shed there should be fine sand, perhaps six inches deep, but no board floor. Pheasants like dust baths and the sand keeps them in excellent plumage and healthy. It also enables them to free themselves from vermin, if any chance to attach themselves to the fowls.

Having decided to raise pheasants and construct the shed and runway, the prospective farmer must settle the question whether to breed birds for the "fancy" market or as stockers for game preserves and country estates. Then he must procure the kind of pheasant most suitable for his purpose.

The English ringneck and the Chinese ringneck are the only pheasants suitable for liberation in game preserves in this country. The Chinese variety is known under several names, such as Mongolian, and "Denny." the last name applied only in the United States for reasons that will appear later. The Japanese, the Reeves and the Bohemian pheasants are well adapted for the covert, but the others mentioned have proved the greatest success.

\section{Recipes for Something Good to Eat Besides Pheasants}

Most delicious Almond Pie. (It tastes different from all others. Once relished it will never leave your memory.)

$3 / 4 \mathrm{lb}$. flour; $1 / 4 \mathrm{lb}$. sugar, $1 / 2 \mathrm{lb}$. butter; a little baking powder; yolks of 4 eggs; 4 tablespoonfuls of milk. Prepare to a dough.

\section{FILLING}

$1 \mathrm{lb}$. fine mashed Almonds; $1 \mathrm{lb}$. powdered sugar, whites of 5 eggs beaten; juice of $1 / 2$ lemon or 1 tablespoonful of brandy or arrac. (To mash almonds, use meat chopper.) Bake about $11 / 2$ hours in slow oven.

\section{A DELICIOUS ALMOND CAKE}

$1 \mathrm{lb}$. butter; $1 \mathrm{lb}$. powdered sugar; $1 / 4 \mathrm{lb}$. almonds, ground fine; 4 eggs; 1 lemon; $1 \mathrm{lb}$. flour; 2 teaspoonfuls baking nowder. Bake from $11 / 2$ to 2 hours. 
Of the varieties sutable only for the aviary the best to raise are the Golden, Silver, Lady Amherst, Swinhoe and the Argus. The last named is a vision of beauty when his feathers are spread, but is rarer than the others. The Swinhoe is distinguished from all others by the fact that the hen is almost as gorgeous in raiment as the cock To make a start, either eggs or pheasants themselves may be procured. If eggs are obtained, they may be hatched under an ordinary farmyard hen, or, better yet, a bantam hen, which is the best of mothers. The eggs hatch in from twenty-two to twenty-five days, according to the variety whence they come. The chicks have a tendency to escape through tiny holes for two or three days, until they learn the call of the mother hen, and in consequence the nests wherein they are hatched should be carefully inclosed in a dark coop.

After the third day the chicks will respond to the mother's call and want food.

On the question of the best food for the chicks the breeders differ. This need not bother the beginner, however. If he gives them boiled custard, made dry and crumbly, he will experience no trouble. If in addition he can give finely chopped lettuce or onion, his chicks will thrive the better. Some maintain that the chicks cannot be raised without some kind of

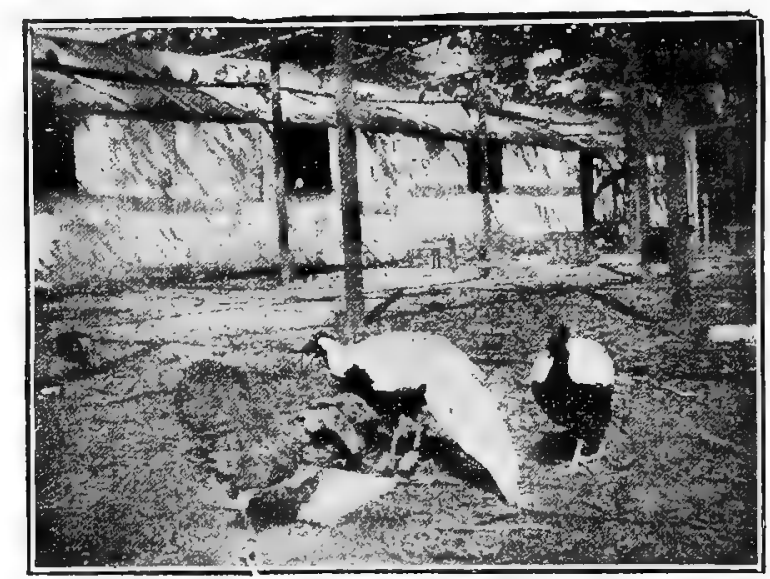

SILVER AND GOLDEN PHEASANTS KEPT IN THE SAME RUN WITH SQUAB BREEDERS

animal food, such as maggots or some kind of meat mixture, but such persons are usually interested one way or another in the exploitation of some proprietary food. As the chicks grow, meal and grain may be substituted for soft food. The young ones may be taken from the mother when six weeks old and put into a shed and runway of their own. At the age of four weeks the young birds will begin to fly, and as they are very wild it is best to clip one or both wings. As they grow to maturity they become tame and the "fancy" varieties may be set free on lawns.

At night the pheasants should be driven into the aviary. In this the roosts should be of $2 \times 4$ scantling hung about two feet from the ground, If the game varieties are raised, they should not be released from the wire inclosure until ready to liberate on the estate where they are expected to propagate in the wild state, for they are wild and would vanish if let loose before their allotted time.

During the laying season some care must be exercised to prevent the loss of the eggs. The pheasant makes a primitive nest at best, and often no nest at all. From her perch on a roost the hen often drops the eggs on the ground. The breeding season for pheasants is usually from April to August. 


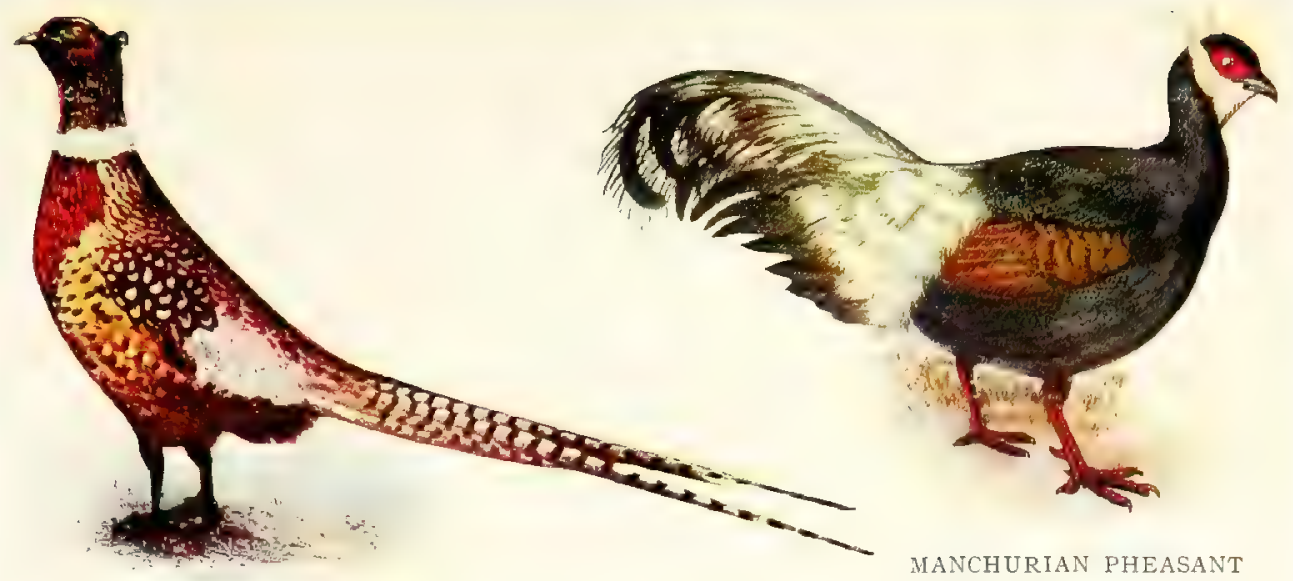

CHINESE PHEASANT

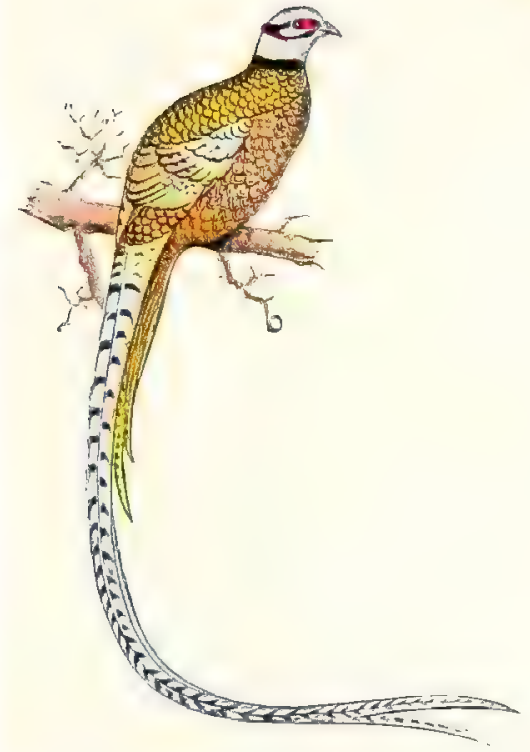

REEVES PHEASANT
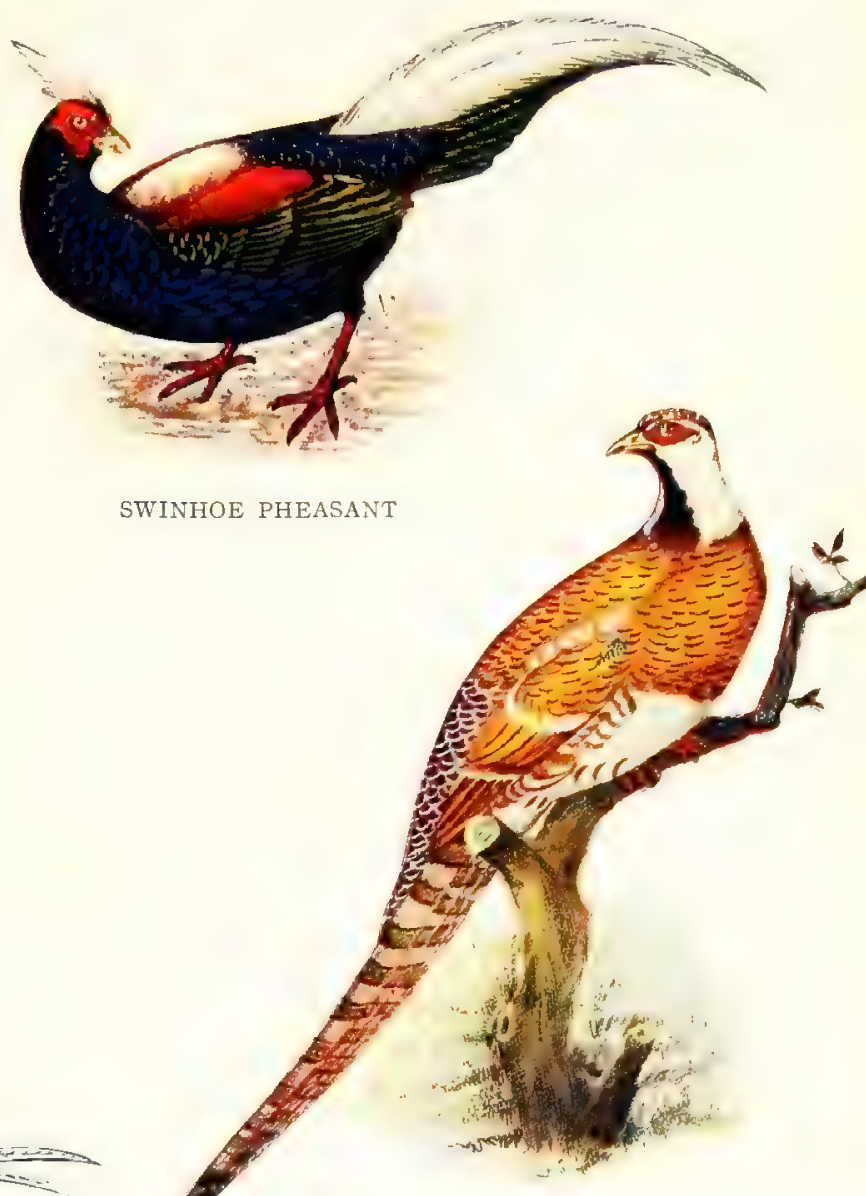

ELLIOTT PHEASANT 
Some pheasants mate in pairs, others are polygamous. English, Chinese Japanese and Bohemian species should be mated one cock to four hens; Silver and Swinhoe, one cock to one hen; Elliott and Reeves, one cock to two hens, and Golden and Lady Amherst, one cock to two hens. The beginner will have to pay $\$ 7.00$ a pair for English pheasants the standard price. Reeves and Lady Amherst varieties cost $\$ 25$ to $\$ 30$ a pair, and Goldens and Silvers from $\$ 10$ to $\$ 20$ a pair. The rarer kinds cost a great deal more, running as high as $\$ 600$ a piece.

To show the possibilities of pheasant breeding, it is interesting to look at the work done in Oregon. About twenty-five years ago Judge Denny imported eighteen Chinese ringnecks from China, and liberated them in the valley of the Willamette. State laws were enacted to protect them from the hunter. The flock multiplied with great rapidity. In recognition of his work of establishing in the wild woods such prolific game the Legislature of Oregon gave the birds the name Denny pheasants. Thousands are shot by sportsmen every year, but more of them remain in the woods and meadows of Oregon than of any other game bird that inhabits the State. Fifty thousand of the birds were killed in a single day in the last hunting season, yet it is said there are now more of this kind of pheasants in the State of Oregon than are to be found in all China, their native country.

About the only pheasantries in existence in the

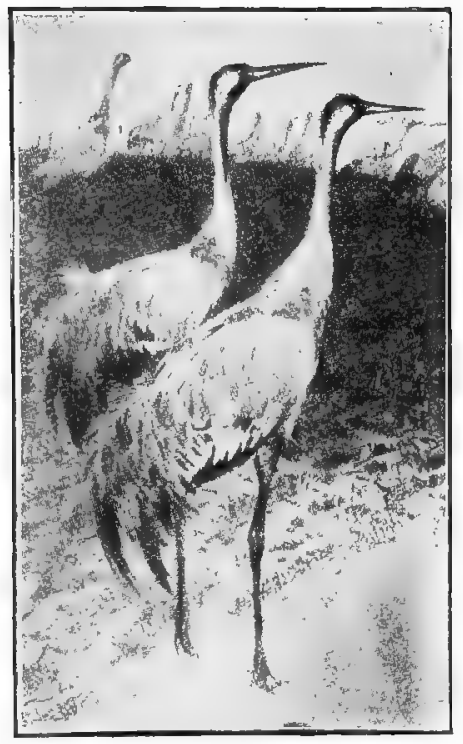

SAND HILL CRANES (Can be raised in captivity) United States are in New York, New Jersey, Massachusetts, Illinois, Colorado and Oregon. On one game preserve in New Jersey, 10,000 to 20,000 pheasants are raised in a season. On one estate in Massachusetts 1,000 chicks and 1,500 eggs are obtained annually.

In order to protect our game and in particular the propagation of pheasants, it is high time that a law licensing gunners should be established and strongly enforced. In a great measure it would do away with all the nuisance of careless boys running at large with loaded guns, and killing most everything that comes before their guns, and endangering the lives of our good citizens. A score of them are killed every season through the carelessness of gunners.

The State of Illinois has already instituted this game law, and charges $\$ 2$ gun license per person, and is enforcing this law very vigorously through the appointments of many game wardens, and no doubt other states will soon follow that statute.

Game for shooting in this country is almost exterminated and we have only pheasants to fall back on; therefore, pheasants are in great demand now. About 250,000 pheasants are imported from Europe yearly and bought up in great quantities by our rich sportsmen to stock their preserves; also imported dead for table

use. Pheasant meat is considered the finest delicacy for the table. 


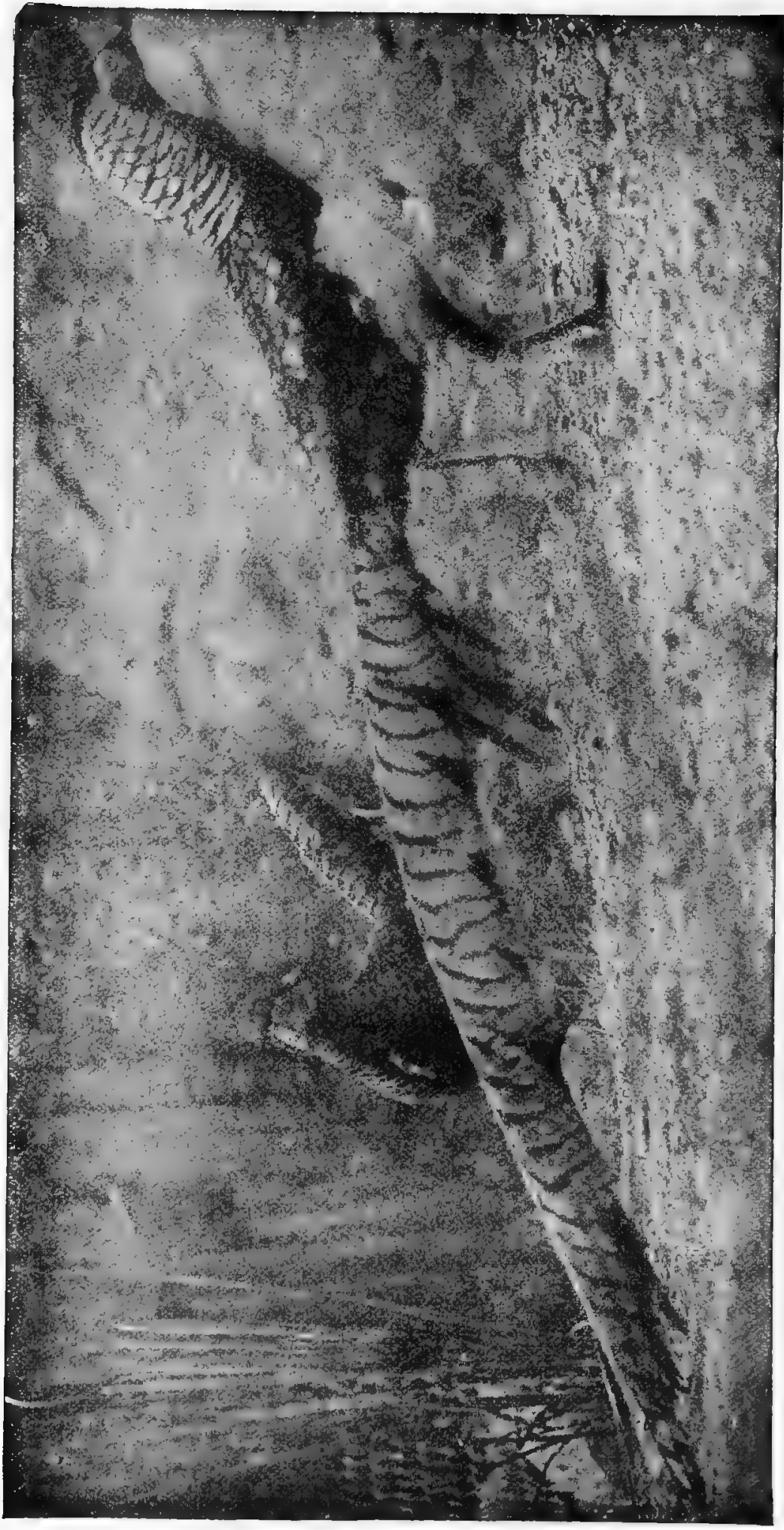
舟些 造 : : 吕故尔

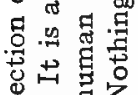
兽舟员 8 造

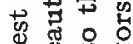
용요

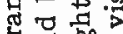

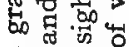

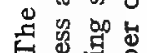
हैํㄹㄹ 


\section{Breeding Pheasants in America}

The Kendrick Pheasantries, City Park, Denver, the largest Pheasantries on the American Continent

Thousands Reared in Colorado. Hardy Game Birds for the United States and Canada. Pleasant and Profitable Occupation for Men or Women. How to Feed and Care for Them.

\section{Written by J. ALDEN LORING}

(A widely known naturalist who accompanied ex-President Roosevelt on his trip to Africa)

By permission of W. F. Kendrick

In America the rearing of Asiatic pheasants is practically unknown when compared to the extensive manner it has for centuries been carried on in the old country. Until the last decade our native game has supplied America's wants, but cheap firearms and repeating and automatic guns have so increased the number of hunters and decreased the amount of game, that the prairie chicken, sharp-tailed grouse, ruffed grouse and bob-white are practically extinct, when their abundance in former years is taken into consideration.

Strange to say, most of the sportsmen and the gun clubs that have taken a serious interest in the welfare of our fauna, instead of trying to solve the problem of successfully propagating the native game birds, have spent most of their money in introducing and liberating foreign game birds.

The greatest success so far attained in this line, has been in Washington and Oregon, where eighteen Chinese pheasants were liberated about 1882, and at the present writing they are very abundant: although large numbers of them are annually killed by hunters.

The so-called English ringneck pheasant was introduced into the Genesee valley of New York several years ago and under present protection they are multiplying and spreading

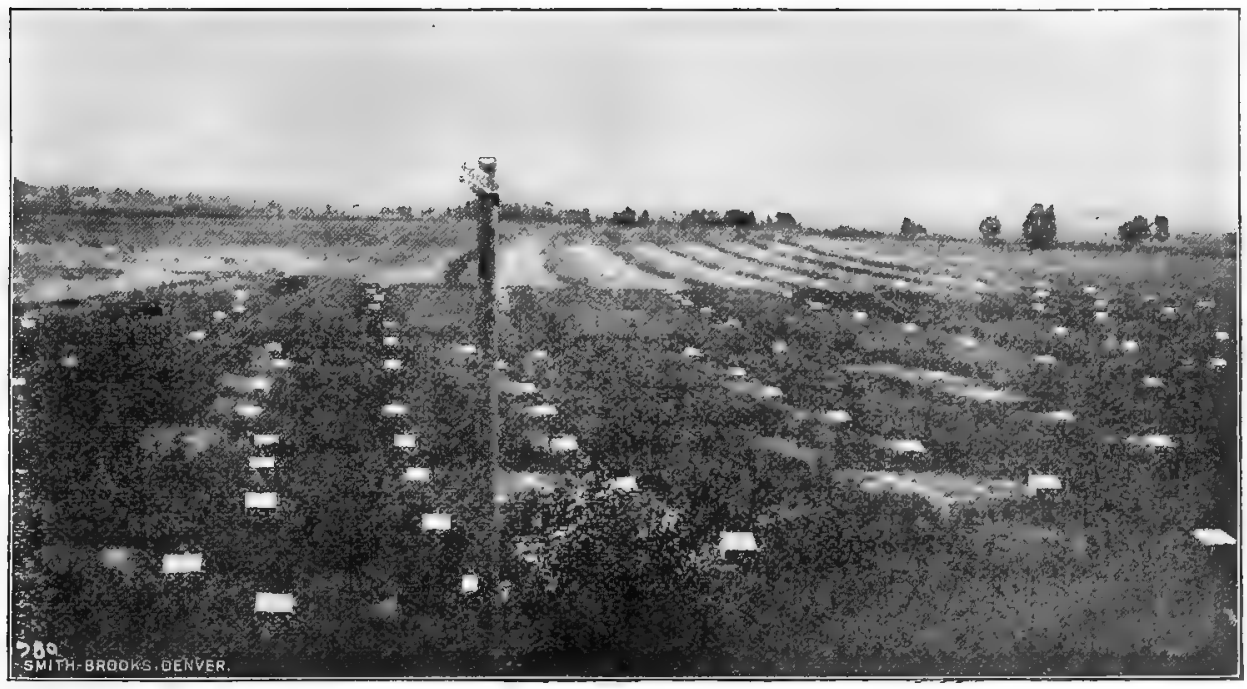

Rearing fields of The Kendrick Pheasantries, show:ng the brooder coops in a one hundred and sixty acre field of alfalfa and orchard grass mixed. These brooder coops are set 30 or 40 feet apart, but it is not necessary to have them so far

rapidly. Many owners of private game preserves have successfully stocked their lands with pheasants.

This sudden demand for game birds for restocking purposes has caused many pheasantries to be established throughout the country. The largest of these is the Kendrick Pheasantry at Denver, Colorado. Its owner, Mr. W. F. Kendrick, is one of those liberal 
hearted citizens, who some ten years ago began raising pheasants for his own pleasure and the benefit of the general public and the good they will do the adopted state in which he regained his health.

Aside from maintaining a number of well filled aviaries for exhibition purposes at City Park Zoo, Mr. Kendrick has liberated large numbers of pheasants. Last year alone he set 15,000 eggs and freed about 6,000 birds and this year he expects to set between 20,000 and 30,000 eggs, and will liberate probably two-thirds of his summer's hatch.

If proof were really needed, Mr. Kendrick's willingness to reveal the many secrets of raising pheasants that have cost him years of experience and thousands of dollars, is convincing that he is sincere in his desire to become a public benefactor.

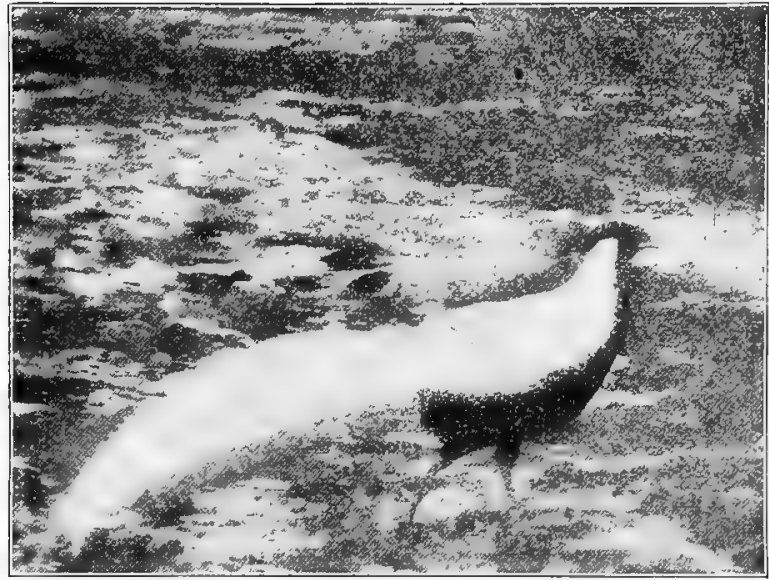

SILVER PHEASANT COCK IN FULL PLUMAGE

"When I first started my pheasantry I knew no more about it than a practical experience in rearing chickens had taught me," said Mr. Kendrick. "All the literature I could gather on the subject, told how delicate the little pheasants were and what close attention and $\mathrm{ex}$ treme care in feeding they re quired. Wishing to begin right, I imported an English gamekeeper, who was supposed to have had wide experience in the work. He was full of all kinds of nonsensical ideas-for example, one was that if the pheasant chicks were fed the same kind of food on a warm day that they were given un a cold day, they would die. The result is that we have come to the conclusion that many of the pheasantries mollycoddle their birds too much, and that raising pheasants is not much harder than raising chickens and not near as difficult as rearing turkeys.

"The birds upon which we rely for our summer's hatch are kept during the winter in City Park. Thousands of them. cocks, hens and young birds of the season before, are grouped in the large aviaries. The species which we make a specialty of raising is the pure Chinese ringneck pheasant, but all of the species that we have, the Chinese, Lady Amherst, Reeves, golden, silver, versicolor and others are polygamists.

"When the naked skin about the head of the cock bird begins to assume its brilliant hues. about the first of March in this locality, it is a sign of the approaching breeding season. Then we begin to group the species, placing one male and three females of the silver golden and Reeves in an inclosure, and four females and one male each of the other species together.

"Pheasants are very prolific. A hen ringneck will lay about sixty eggs in a season, a Lady Amherst and a golden will average twenty-four and a Reeves and a silver pheasant, between thirty and forty eggs. The eggs are all about the same shape, but they can usually be distinguished by their size and color, which varies from white to dark blue.

"The laying season out here begins about the last of March and from then until the middle of August the keepers are busy gathering the eggs that are found scattered over the ground in the different inclosures. for in close confinement pheasants rarely build and lay their eggs in a nest. As fast as a supply is gathered, we rush them off to our country hatching and brooding grounds. 
"During the first of the season the eggs are collected twice a day but as the weather becomes warmer the rounds are made three and four times, for the sun is apt to start incubation and the cool nights might chill the life germ and weaken or kill it. Then, there is danger of the pheasants pecking holes in the shell and eating the eggs, as they are sometimes wont to do.

"When liberated pheasants will nest and rear their young, but in the comparatively small inclosures that we give them, there is no use trying to get them to breed. We decided on that long ago. Even when they succeed in hatching out a brood, the old bird cannot supply the young ones with the needed insect food, and we are unable to handle and feed them as we do chicks that are under the tutorship of a hen. Then we tried incubators and while we succeeded in hatching the eggs, the chicks soon sickened and many died of diarrhoea.

"After these and other experiments, we have found that the common mongrel or barnyard hen is the best means of hatching the eggs, and makes the best foster mother to brood the little chicks until they can take care of themselves. Bantam hens are also good. but they cannot cover a large setting of eggs. This season $I$ have employed an expert incubator man to try artificial hatching and rearing. I expend thousands of dollars experimenting for the benefit of the public. It requires about a dozen gamekeepers and assistants during the rearing season.

"Last year we had 1,000 hens working for us, each one covering from fourteen to eighteen eggs. Sentenced to solitary confinement for twenty-three days with leave of absence just long enough to fill one's stomach, may not be as tiresome as manual labor, still it must get

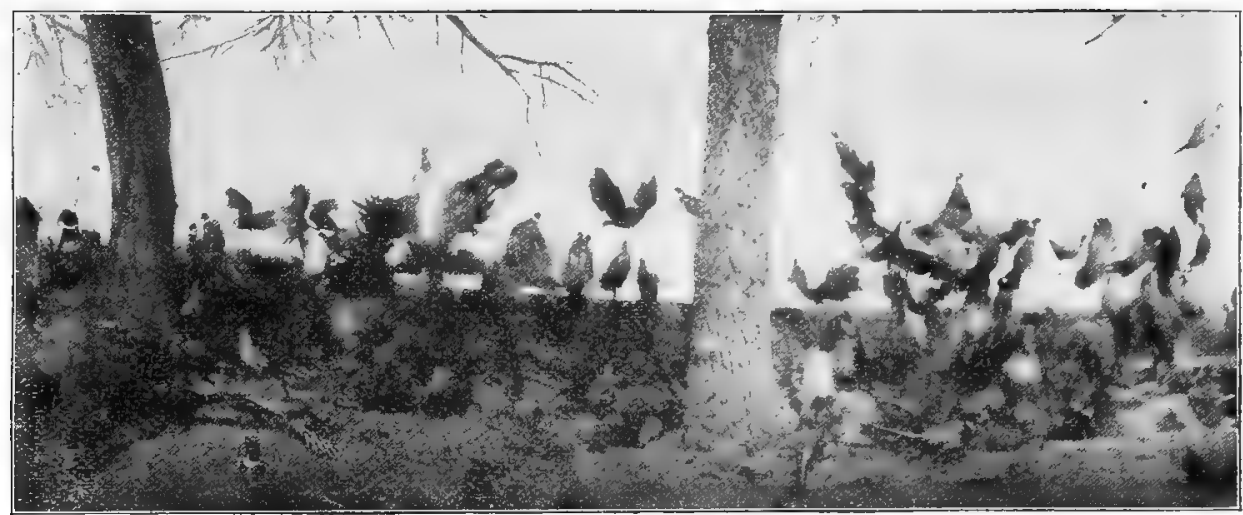

A BUNCH OF FRIGHTENED PHEASANTS

This Photograph shows a flock of frightened Chinese pheasants rising for flight in a field of The Kendrick Pheasantries

awfully monotonous, before the time expires. We are glad that there is no such association as the 'Western Federation of Feathered Incubators.' or the 'Foster Mothers' Protective Union,' for I fear its scratching delegates would order a strike at once when they discovered the tricks we practice on their members.

"We have adopted the plan of not letting the hens hatch the eggs, but as soon as the little chicks peck through the shell, we hustle the whole setting into an incubator and let the pheasant chicks stay there until they have come out and are dry and strong enough to run about. This lessens the danger of their being trampled by the hens while they are weak and helpless. In the meantime her henship is presented with a beautiful set of China eggs to keep her occupied until we can smuggle the chicks back to her.

"As far as possible we follow nature. For instance the nesting and brooding coops are all located in the meadows and the nests are placed on the ground, where the eggs get the moisture they require. The nesting material is some fine substance in which the chicks cannot tangle their feet or get strangled fine hay or fine straw is best. 
“The ringnecks' eggs are nearly all fertile and we often get a perfect setting, that is, every egg hatches. During the first of the season we use fourteen or fifteen eggs to a setting, but when it gets warm, from sixteen to eighteen eggs are placed under a hen. Last year the eggs accumulated so rapidly that we did not have hens enough to handle them, so we placed them in the incubator for a few days and gave them to the hens as fast as we found birds under which to place them.

"It takes from twenty-three to twenty-four days to hatch ringneck pheasant eggs, and about twenty-one days for golden and Lady Amherst eggs.

"The coops are placed about twenty feet apart and as you look over the breeding grounds it reminds you of a miniature white city. Some of the coops are surrounded by a pen twelve inches high, in which the chicks are kept prisoners for the first four days. This is necessary because experience has taught us that young pheasants, like young partridges, will run away and become lost if given their liberty as soon as hatched. They do not seem to understand the language of their foster mother, but after the lapse of three or four days they learn her call-notes and obey, returning to her for food and to be brooded at night. We do not, as a rule, liberate the hens with their broods.

"During the first twenty-four hours we do not feed the chicks, they do not require it, as the nourishment obtained from the yolk of the egg is sufficient. For the first four days they are fed plain table custard mixed with chick food. Then we gradually break them in on a more substantial diet; eggs that have been dropped into boiling water and allowed to cool in it, then crushed through a piece of common wire mosquito netting and mixed with Sprat's Pheasant Food, bread crumbs, corn meal and crumbled cornbread. After a week of such feeding we change again, this time gradually diminishing the amount of boiled egg and adding raw food, such as fine corn meal, crushed grains, and finally the best of raw Hamburg steak. We keep them on this food until they are old and strong enough to be given the regular food fed to the adult birds; buckwheat, wheat, cracked corn, kaffir corn, raw pumpkin, squash, sugar beets, mangel wurzel, cabbage, lettuce, dandelion tops and boiled potatoes and turnips. The young pheasants are very fond of dandelion leaves and roots and people bring bag after bag of them to the park for us, as they dig them from their lawns.

"For the first three months we feed the young birds considerable chopped meat so as to induce a rapid and hardy growth, if sour milk is plentiful we make cottage cheese for them.

"Aside from the fact that when being reared they should be kept on a grassy meadow or flat, the care of pheasants should be quite like that given to chickens. Last year we experimented with a few of our birds and were so well pleased with the result that we shall adopt it on a much larger scale this season, and if we are as successful as before, the rearing of pheasants will be no more difficult than rearing chickens.

"We have tried feeding the chicks on maggots as they do in Europe, but so many of them died of ptomaine poison that we found it an utter failure in this section of the country.

"When we have old birds confined that we have decided to use for restocking the covers, we liberate them at a time when grasshoppers and insects are abundant. But we pay little

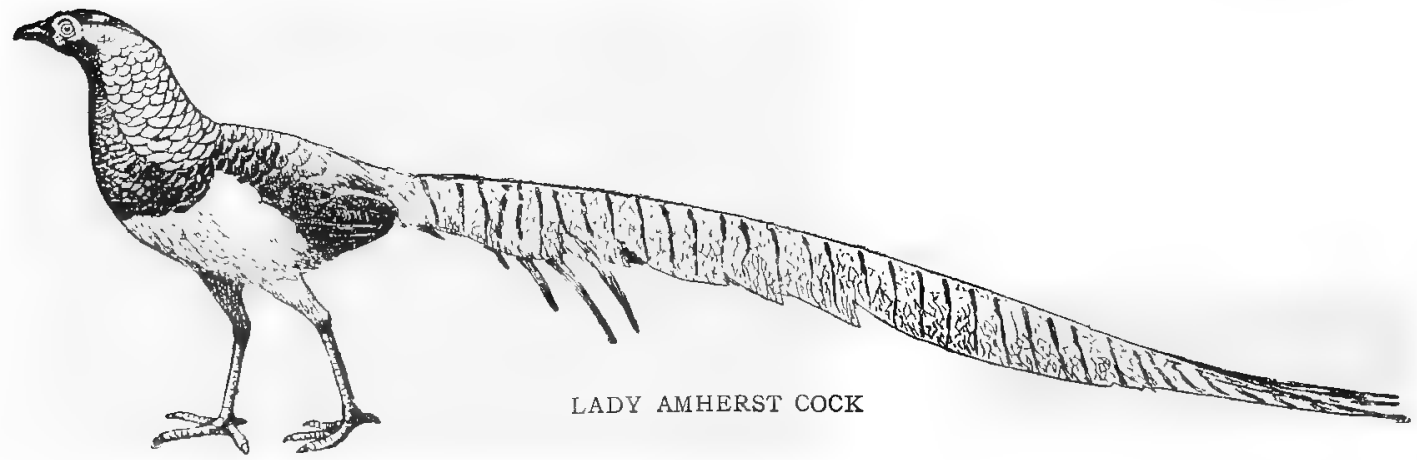


attention to the young birds used for that purpose, for after they pass the stage where they require artificial food they naturally leave their foster mother and seek their freedom.

"One of the greatest dangers to the successful rearing of pheasants is from lice. We begin to fight these pests from the time that the sitting hens are brought to the grounds until the pheasants are able to care for themselves, after which they spend much of the time rolling in the dust and sand which is Nature's method of keeping off these insect pests.

"The coops and chicken houses are thickly coated with whitewash and they are frequently sprinkled with other insect-preventive washes. In a season we use barrels of different washes.

"As soon as the broody or sitting hens are bought, they are thoroughly dusted with insect powder and their feet and legs are dipped in kerosene oil. The hens are placed on trial nests and given a setting of China eggs. A few days later the hen is transferred to the regular sitting boxes, nesting material that was in the trial box is burned and the coop fumigated. Then the old lady receives her set of pheasant eggs and is disturbed as little as possible until the eggs hatch. This method eliminates the possibility of insects infecting the chicks. One should never put a hen on pheasant's eggs immediately after her legs have been oiled, for the oil will kill the life germ.

"Body lice are not very harmful, the head lice are the ones we dread and fight most. When the young pheasants are taken from the incubator and before they are placed in the brooding coop with their foster mother, their heads and the bare spots beneath their wings and about their thighs are well greased with vaseline and a very weak solution of carbolic acid. This operation is repeated about every week until they become difficult to catch.

"Students of Natural History enjoy visiting the brooding grounds during the height of the season, from June to August, when hours at a time can be spent watching the little birds from a distance, as it is risky to allow strangers to enter-except by special invitation-the brooding grounds as they might unintentionally trample on the young birds, which, when

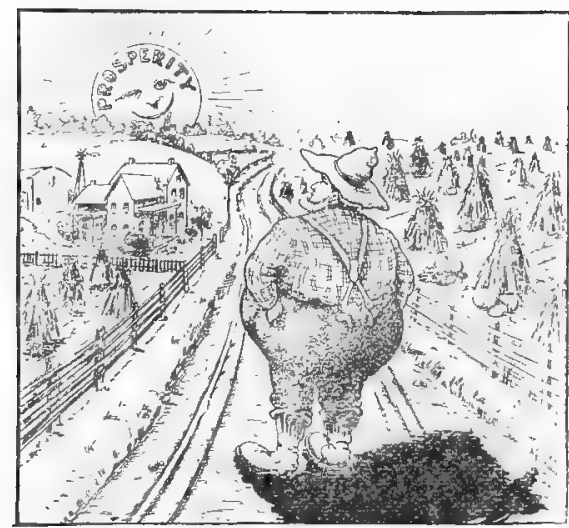

If you want to be as prosperous and fat as this farmer, breed pheasants they are frightened run and hide in the grass instead of going to the mother as an ordinary young chicken does. Even the gamekeepers have to exercise great caution in this respect and walk as much as possible in the wellbeaten paths leading from one brooding coop to another in the rearing fields. These coops are moved on alternate days about the length of one on to new grass on account of cleanliness.

"You see the natural instinct of all game birds of this family to hide at the sight of danger, causes the young pheasants to take shelter in the grass as soon as they get scared. But the crafty little chicks are much brighter than would be supposed, for they soon learn the uniform of the keepers and will come for their food quite like little chickens. but the instant that a stranger appears they scud for shelter. Even when I visit the grounds I have to remain motionless for some time before they gain confidence and come out of hiding. In the meantime little heads appear here, there and everywhere, and finally they leave their hiding places,

"Thousands of pheasants ranging in age from a few days, to birds almost ready to fly, swarm in the grass. They do not play as do young animals for young birds seldom frolic, but as you look over the meadow you see the grass waving here and there where the multitude is busily engaged catching grasshoppers and insects. 
"People from Denver and picnic parties from adjoining villages, come to my country pheasantry and visit my exhibition aviaries in City Park, where I rear just.enough young birds, in plain view from the walks and drives, to give all interested an idea of what the industry is like.

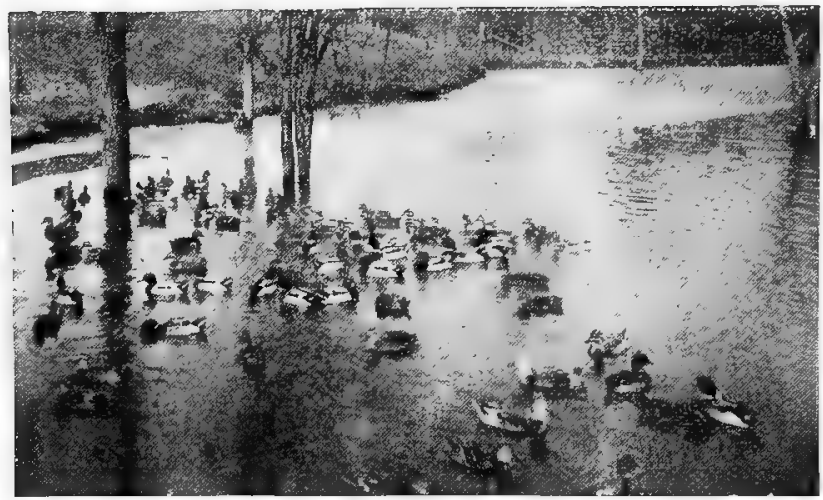

WILD MALLARD DUCKS

"It would be interesting to know just how many insects a pair of these birds will eat in a year. Nearly 1,200 wire worms have been taken from the crop of a single pheasant, and for another bird 440 grubs of the grand-daddy-long-legs, constituted a single meal. That they are great destroyers of the seeds of noxious weeds is well known.

"It would not be supposed that a bird like a pheasant would kill those destructive little field mice.

or meadow mice, as they are called. But they do, and it would surprise one to see how quickly they do it. Pheasants are perhaps the swiftest birds afoot of all the small Gallinaceous game, and they can pick up a mouse before the race has fairly begun. Then they thrash it upon the ground and keep pecking it until it is dead, after which they eat every vestige of the body but the skin and skull. Young mice they swallow whole and cases are on record where they have been choked to death by the rodents.

"Pheasants do not scratch like chickens, their bill takes the place of their feet. They will even peck a hole through any moderate thickness of ice for water, and in the same manner they dig out buttercup bulbs and insect larvae. They do not roost on the ground until the foliage leaves the trees, but spend the night high up among the branches where they are not subject to the attacks of the predatory animals. Their most dreaded enemy is the western horned owl.

"With the ringneck pheasant the bright plumage of the males begins to appear about the fourth month, and in eight months they are gorgeously plumed. The golden, silver and Lady Amherst pheasants do not get full plumed until the second year. The difference between the sexes is first noticed when the birds are about two months old-then the tail of the male is the longer. Even when adult, it is hard to distinguish the different species of hen pheasants, and only an expert can identify them. There is practically marked difference between the female ringneck and the versicolor birds.

"No, we don't confine our experiments to pheasants only. We consider it a great favor when sportsmen send us a setting of eggs of some other game bird. In fact, at the present time we have mixed in with our pheasants, scale partridges from southwestern United States, California mountain partridge, valley partridge and the eastern bob-white. We have had scale partridge and bob-whites build their nest and rear their young in captivity, and we have incubated and reared large numbers of bob-whites.

"Wild ducks' eggs hatch easily and the ducklings are pretty and interesting creatures. The species that naturally feed upon wild rice, grain and seeds are easy to rear, but the fisheating kind are more difficult We have to clip or pinion their wings or they would migrate south in the fall with other wild water fowl.

"A friend of mine owned a flock of wild geese that he neglected to pinion, and one day in the fall he had the pleasure of seeing then mount high in the air and head for the South 
But as he had expected, they returned in the spring, their identity being established by the holes made in their webbed feet with a chicken punch.

"Yes, pheasants, particularly the Chinese ringneck, are very hardy birds and in their native countries some species range up into the extremely high mountains. Those that I have liberated here are multiplying by the thousand and are doing finely. I believe that they can easily be acclimatized in any suitable locality in the United States or southern Canada. It would be difficult to find a better cover for them than is to be had in those portions of Alberta and Saskatchewan, where clumps and groves of poplar trees abound, affording choice loitering places. The work, too, is clean and very fascinating, and could be made profitable for men and women."

The pheasants that have been introduced into this country have taken up their home in the brushy skirtings of the woods, fields and country roads, where there is also a rank growth of weeds and grass. They can likewise be found in and near marshes, but unlike our ruffed grouse, they do not inhabit the heavy timber; their habits resembling those of eastern bobwhite.

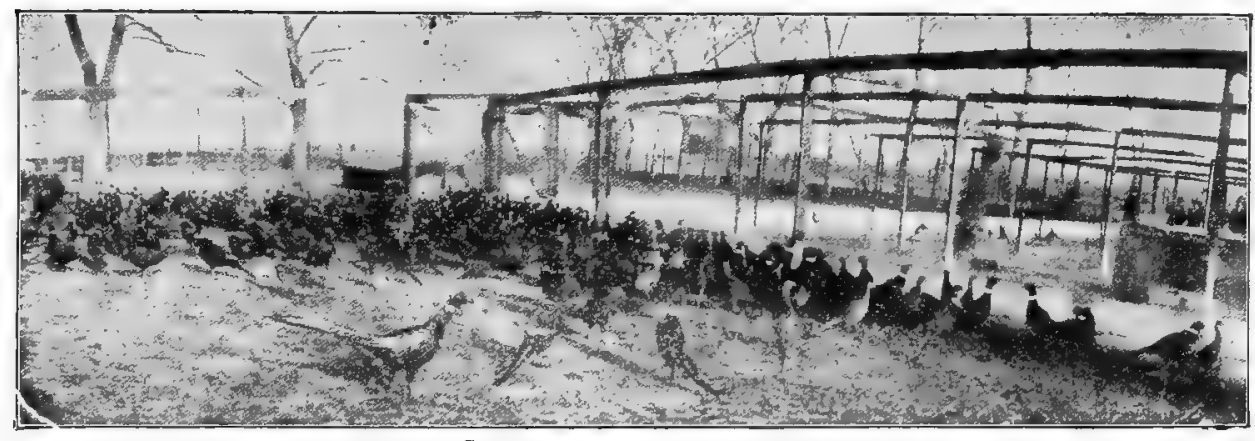

A corner of The Kendrick Pheasantries at City Park, Denver

In sections of the country where the pheasants have been protected since their introduction, they are very tame and lie close, allowing a person to almost step on them before taking flight. In fact, the writer can recall an instance where a hen, hiding in some reeds, could easily have been caught in his hands.

During a day's hunt indulged in by a friend and myself near Albany, Oregon, we bagged twelve birds and must have flushed at least a hundred, two-thirds of which got up far out of gunshot. I was astonished at the amount of shot a cock bird could carry away. Many times, judging from the cloud of feathers, we literally filled the bird with lead yet he would continue his course until out of sight.

The cock old pheasants are armed with long spurs like those of a rooster. They are aggressive birds, constantly fighting with one another in the spring, during mating time, but during the balance of the year they are quiet as quail or common birds.

I do not agree with Mr. Kendrick placing the coops only 40 feet apart. The reason I advise to distance the coops at least 80 to 100 feet apart is in order tor the chicks not to stray from their original mother and coop. If the chicks are of different sizes they are in danger of being killed, if by mistake they get into another hen's coop, because some hens are very cross to strange chicks and will pick them to death. Again if the chicks are of the same size they may take a fancy to a certain hen, crowding into one coop at night and not being properly brooded get chilled which is in many instances fatal to the chicks.

To avoid loosing your good valuable time looking for your tools make it a point to have only one and the same place for them and a handy one. 


\section{Description of Pheasants}

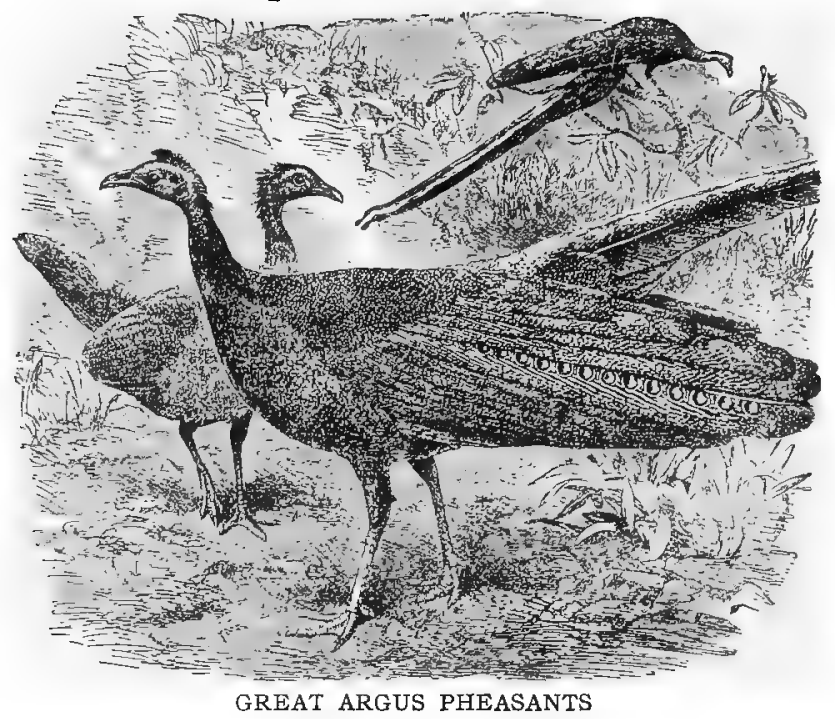

His display of plumage is a wonderful sight. It has no brilliant colors, the beauty of the Argus is chiefly in its shading. The cock's two center tail feathers are remarkable, being over four feet long, very broad and curiously twisted at the end. The plumage is shaded with ochre, senna and white, and resemble bells lying in a socket, when the feathers are in vertical position. They are very thin and delicate, so that, seen from behind, they look like stained glass. The A rgus thrives well in confinement, but require protection from the weather.

Characteristic of the male bird is the elevation of his wings The primary feathers upwards and seemingly looking at the hen out of the corner of his eye and alternately moving the large tail feathers outwards and inwards. When full grown, they weigh from seven to twelve pounds per bird. Breeding season, May-August; hen lays about twenty eggs in a season.

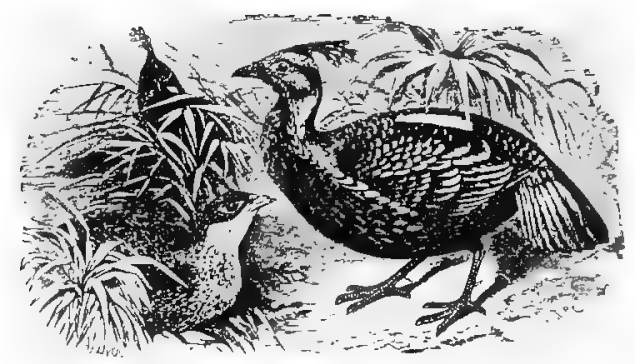

THE IMPEYAN OR MONAUL PHEASANTS

The Monaul is a heavily formed bird equal to a very large owl in size; the legs are short and powerful and the tail is like that of a pigeon-flat and slightly rounded at the end. The color of plumage is burnished green, running into metallic purple and blue.

The Lancelot feathers are bright purple changing into green with a golden glance. The middle of the back is white, the rest of the plumage being rich blue glancing with green and purple, highly glossed. They do not come into full plumage till the second year. Their weight when full grown, is from three to five pounds.

Impeyan are poor breeders, a hen lays about ten eggs in a season. 


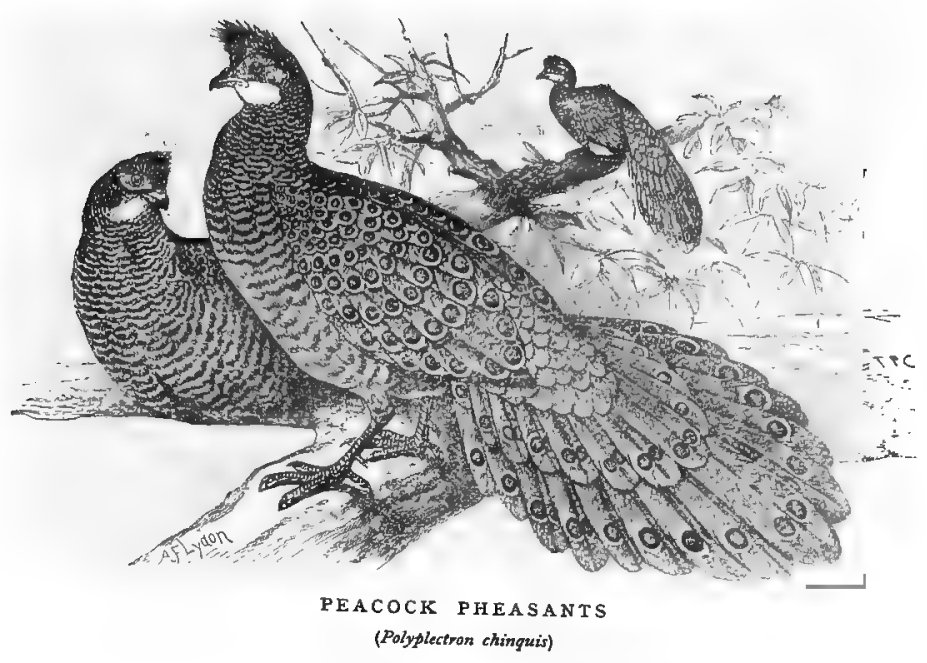

These birds look very much like our native peafowl, extremely handsome, having the peacock eye all over the back. In their native state, they breed four times a year. They weigh from two to three pounds when full grown. The sexes are very similar, hens lay about twelve eggs in season.

Bohemian pheasants are pure white, size of ringneck pheasant, and excellent breeders. averaging sixty eggs in season.

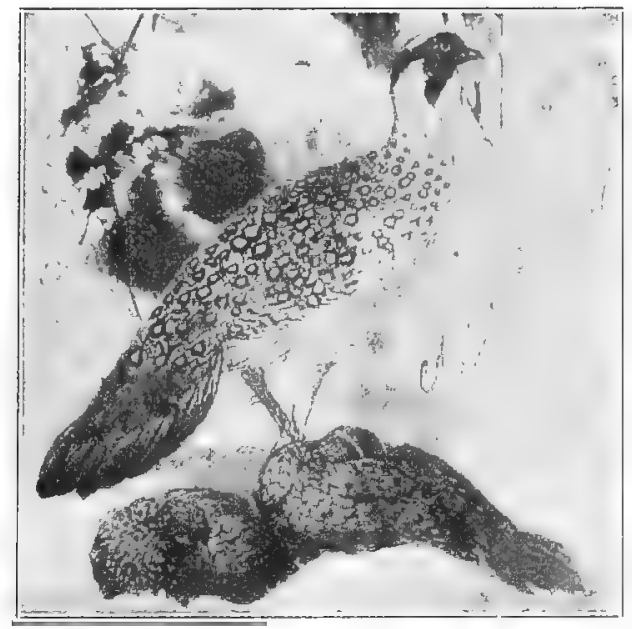

TRAGOPAN-PHEASANTS

Tragopan resemble the Guinea fowl, but with much more brilliant and striking plumage, which is a wonderful combination of bright hues, with delicate markings and shading, very difficult to describe fully. The upper plumage is intricately speckled with black and brown, intermixed with red and varied with pale spots of different colors, the two sexes looking much alike. They are easily tamed and breed freely in captivity; hen will average forty. eggs in a season-April-August. 


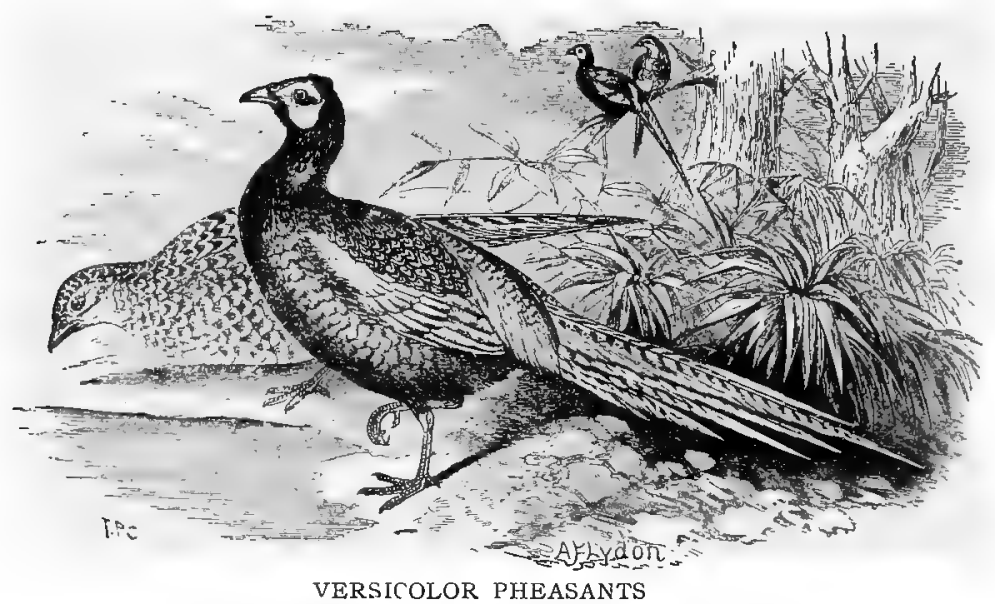

Versicolors are exquisitely beautiful. but have no gaudy colors; head and neck purple, running into a meta11ic blue and green over the body; tail gorgeous grey with black bars; the cock is a perfect dandy with most dignified steps; the hen is of rich brown. Versicolors attain full plumage after the first moult. Breeding season, March-August; hen averaging fifty eggs; weight from two and one-half to three lbs.

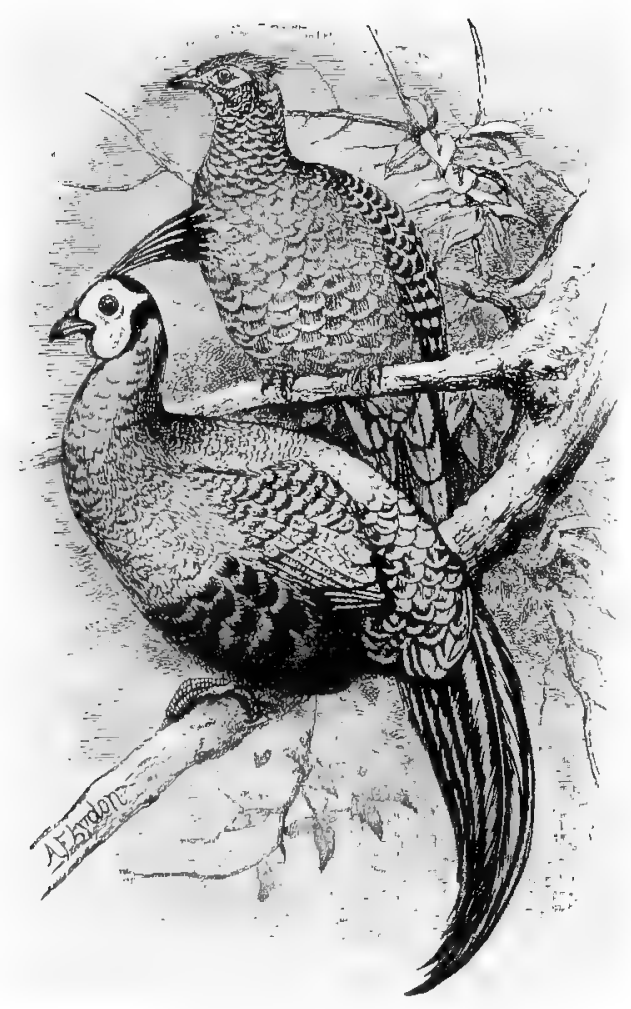

FIREBACK PHEASANTS
The adult cock has a plume of feathers on his head; back of head black; face brilliant red; neck, breast, wings and shoulders light grey, with black tracings saddle yellow shading into brilliant red and orange; tail steel blue; legs red The hen is brown. Firebacks should be kept in pairs. Breeding season, AprilJuly; hen lays about eighteen eggsduring season. Full plumage second season. Their average weight is from three to five pounds. 


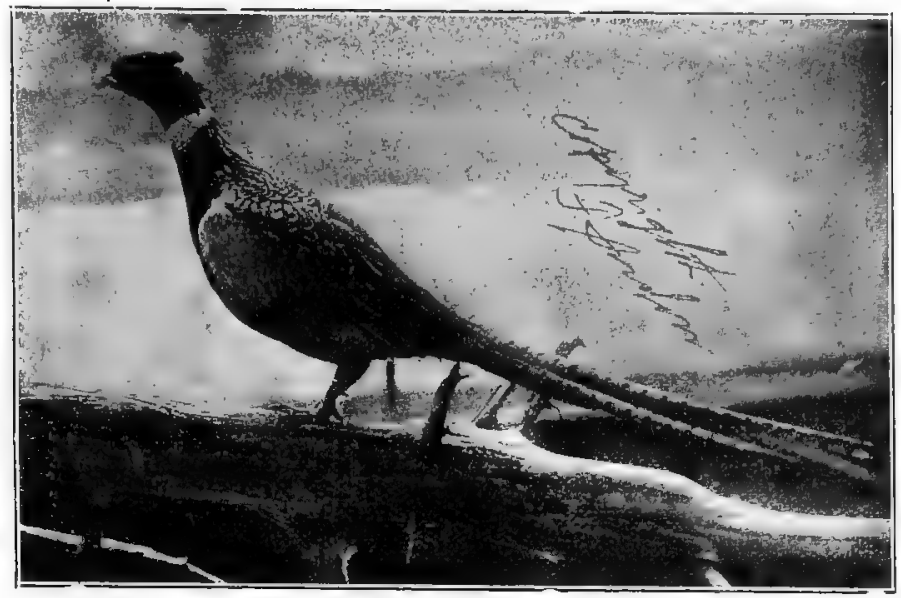

CHINESE OR RINGNECKED PHEASANT-Adapted to the Covert

The male has a light bronze crown, with pure white eyebrows and a broad white ring all round the neck; markings on body in rich purple color and golden buff; the flat of the wing and the saddle are French grey, glossed with green; plumage when six months old. Ringnecks are fine breeders, averaging 75 eggs during breeding season to a hen Average weight about three $1 \mathrm{bs}$. They are used principally for game preserves. Crosses of the China and common species are very prevalent and they are usually called the ringneck pheasant. These birds are perfectly fertile. not only with either pure race but between themselves.

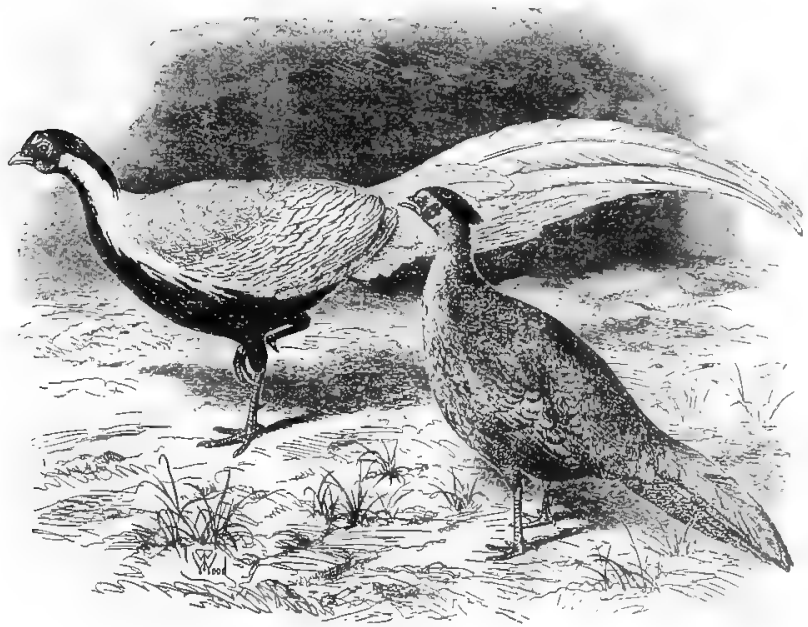

SILVER PHEASANT

Silver pheasants obtain full plumage the second year. The cock's tail reaches two feet in length. In color he is purple black on the crest, and on the under parts to tail; the upper plumage and the tail are white, delicately marked with black lines, the face is covered with brilliant red wattles. The hen is of dull brown, and both have red legs. Breeding season, March-August; hen averages forty-five eggs in a season. Birds are easily tamed and may be allowed full liberty with domestic fowl. Average weight from three to six pounds. 


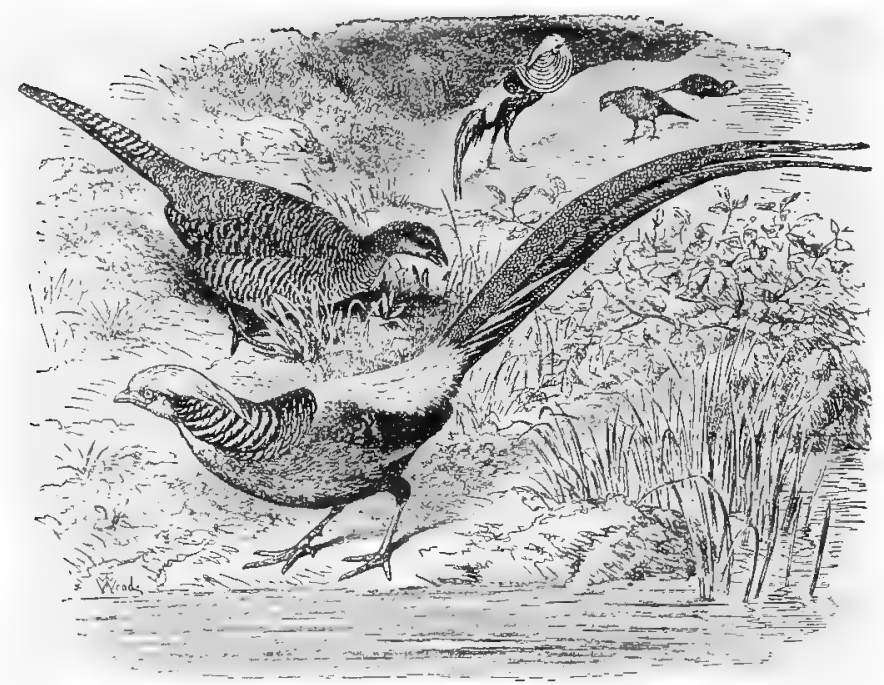

GOLDEN PHEASANTS-King of the pheasant family

It is the most brilliant bird in existence. The adult cock has a crest of pale orange; the longer the crest the more valuable the bird. The tippet is of deep orange, margined with blue-black; breast rich red, shoulder green, wing coverts steel-blue, tail brown, with black spots, and five stiff red feathers on each side. The hen is of a quiet brown; both sexes have yellow legs; eye of male white; of hen, brown. Most all the feathers are valuable for flyhook manufacturing. Of all the pheasants for pets probably none is so suitable, the plumage is extremely beautiful, which is obtained second season. It requires but little room, very hardy, easy to rear and readily tamed. Its graceful movements always charms the human beholder. They breed the first year; hen will lay about thirty eggs in season-April till August. Of all pheasants the golden is the easiest to raise. Average weight two lbs.

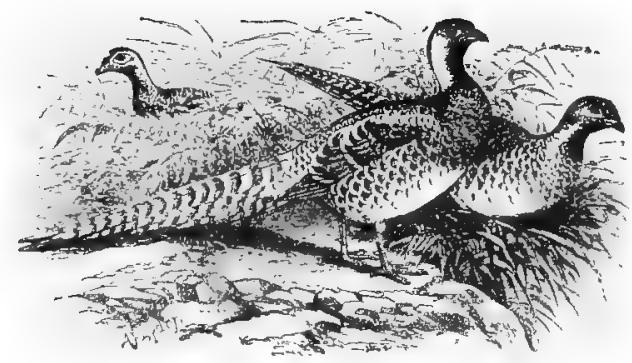

ELLIOTT PHEASANTS

The plumage of the male is very peculiar and characteristic; the general hue is a very rich golden bay, without lacing, varied by a white belly and two white bars on the wing; the tail pale grey, barred with cinnamon. They are very rare birds and require a secluded aviary in order to make them breed. An Elliott hen will lay about twelve to eighteen eggs in a season; average weight about three and one-half lbs. 


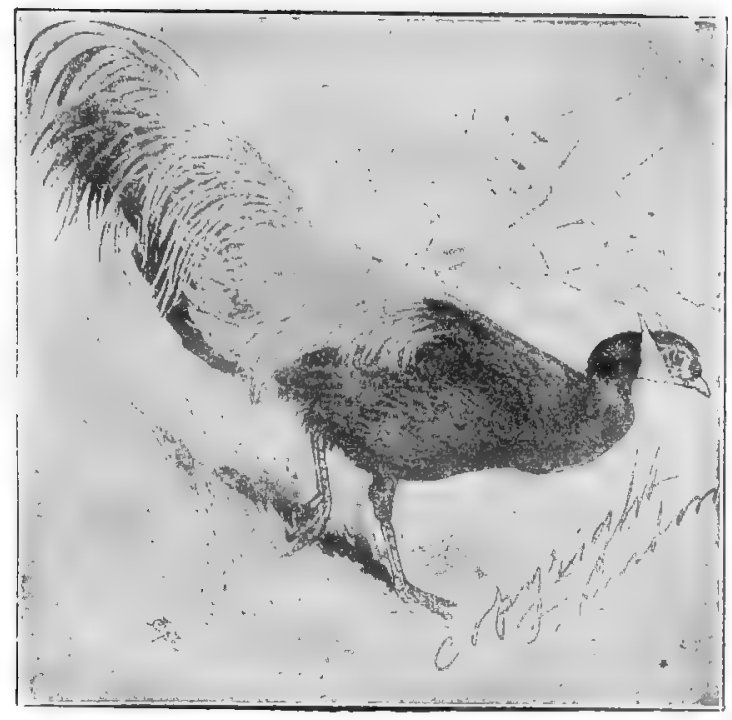

EARED MANCHURIAN PHEASANTS Adapted to the aviary
The eared pheasant differs in many ways from the other species. Both sexes are exactly alike in plumage. The only way to distinguish the male from the female, is by the spurs on his legs. This bird is remarkable for the peculiar arrangement of its plumage. The general color of the body is sombre brown. The true tail feathers are white with dark tips; legs and feet are red. The head is very striking in appearance by the white feathers that constitute the socalled "ears" of the bird. It is a large sized bird, weighing from five to nine pounds. In domestication, they become very tame, more so than common fow1. They are very hardy and the young are easily raised. The hen averages about thirty eggs in season. There are three species of pheasants allied to this breed.

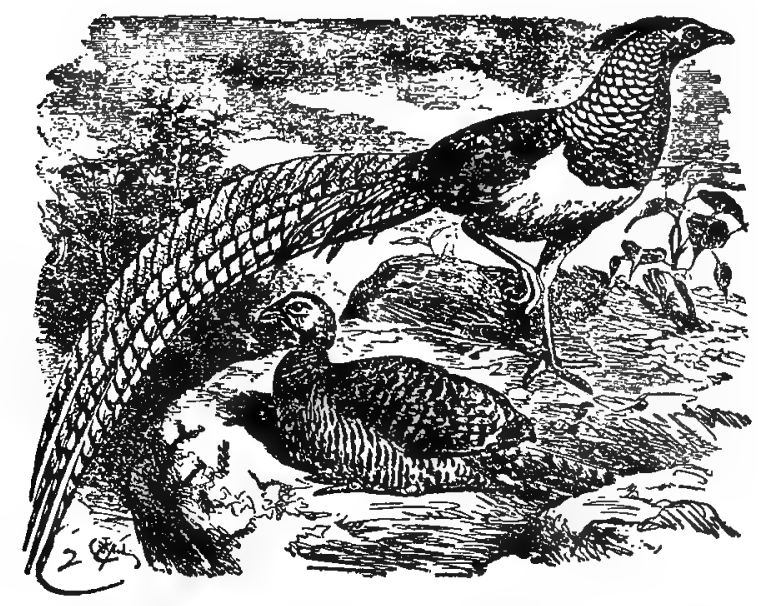

LADY AMHERST PHEASANTS

For aviaries the Amherst is the handsomest; obtains plumage second year. The bird is larger than the golden, the face pale green; crest black, with few red feathers; tippet white, edged and barred with green and black; breast and 'back' green; belly white; saddle orange red, tail of great length, of white color, barred and speckled with rich black; plumage extremely rich. The hen is brown, heavily barred with black; the legs are bluish grey. Breeding season, April-August; hen lays about thirty-five eggs in a season. The Amherst is much easier reared than the ringneck pheasant. The average weight of the adult bird is from two to two and one-half pounds. 


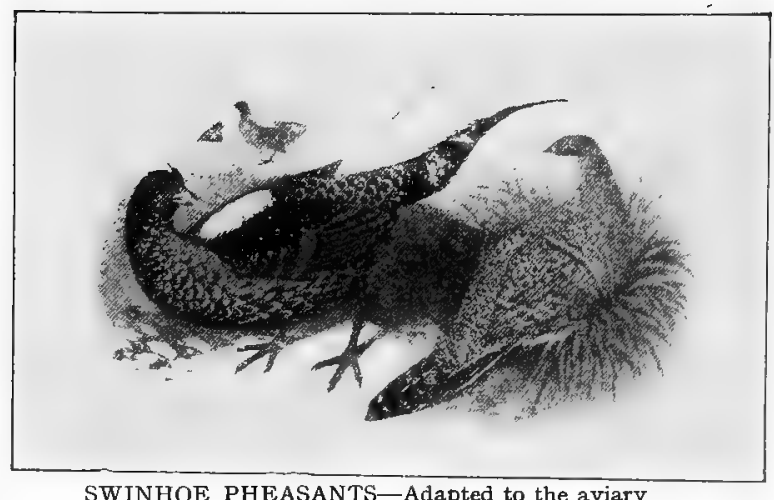

The Swinhoe is a very handsome bird. It is of the same genus as the silver pheasant and requires the same treatment. They originate from Formosa. The adult male has ${ }^{7} a$ pure white crest; red wattles. The underside of body is deep steel blue; lower part of neck, white; shoulder, maroon; wing, brilliant green; centre tail feathers, white lyre shaped, lower ones blue-black; legs, red. The hen is very similar to a silver hen in plumage, but rather lighter and with pointed breast feathers. The average weight of these birds is from three to six pounds; hen lays from twelve to fifteen eggs in season. They do not obtain their full plumage until the second year, are extremely hardy and easily raised and mate in pairs only.

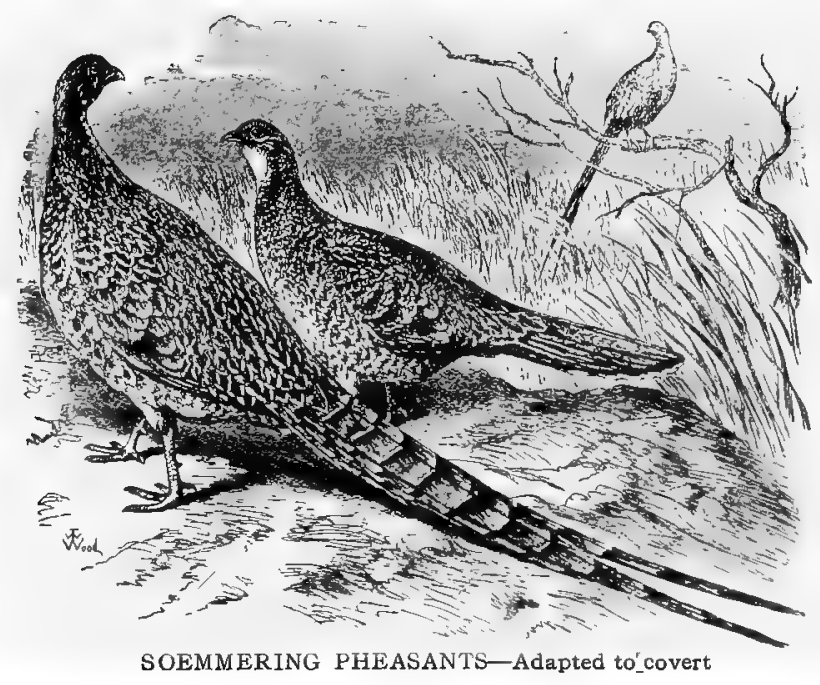

The plumage of the adult male is of golden copper color, every feather having a margin of white and black; tail, reddish, with wide bars, shading into pale colors. The hen has similar plumage but less brilliant; tail, short and round. These are also called copper pheasants. Undoubtedly, these pheasants are among the most beautiful birds on this globe. They compare in richness and brilliancy with almost any specie of pheasant. They are native on the Island of Nippon. In size, they are the same as ringnecks, weighing about three pounds, and are fairly good breeders. Hen averages from thirty to forty eggs in season.

Hens' nests should be made at least seven inches deep so the eggs cannot roll out of the nest, preventing them from getting broken. Broken eggs give hens the first chance to get a taste of eggs and become egg eaters. It is very hard to cure egg eaters. 


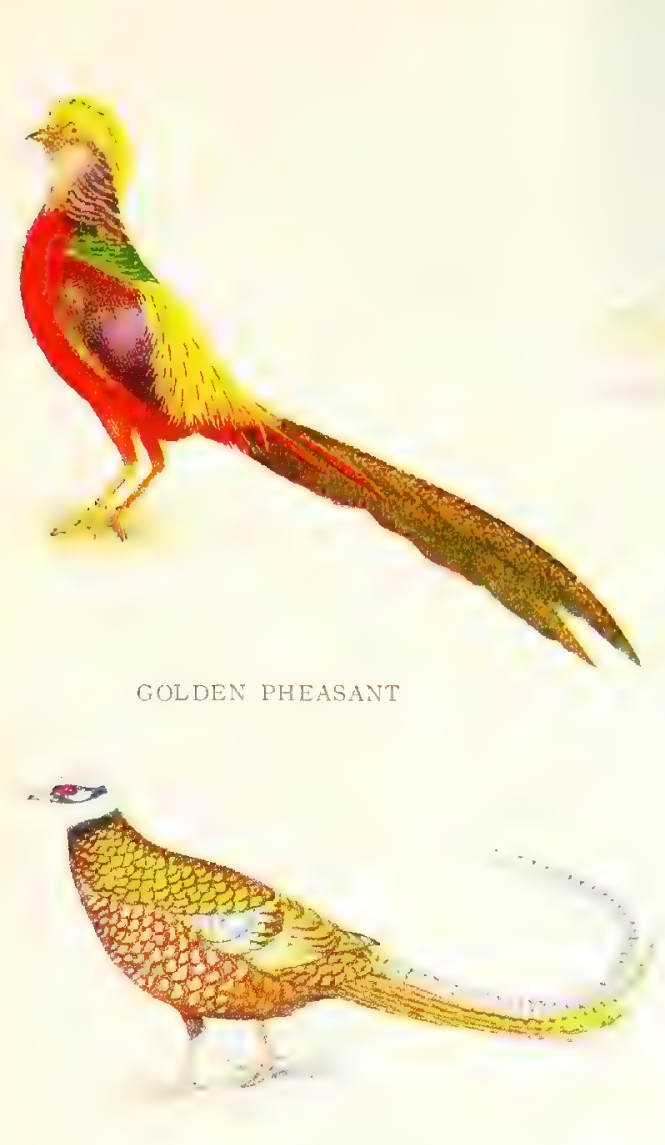

REEVES PHEASANT

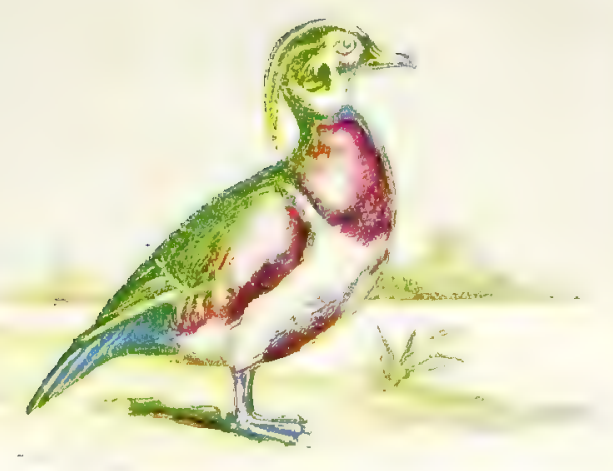

CAROLINA WOOD DUCK

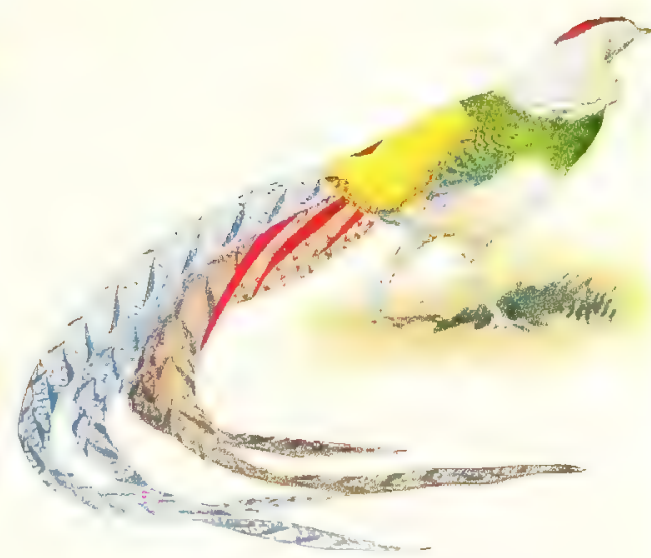

LADY AMHERST PHEASANT

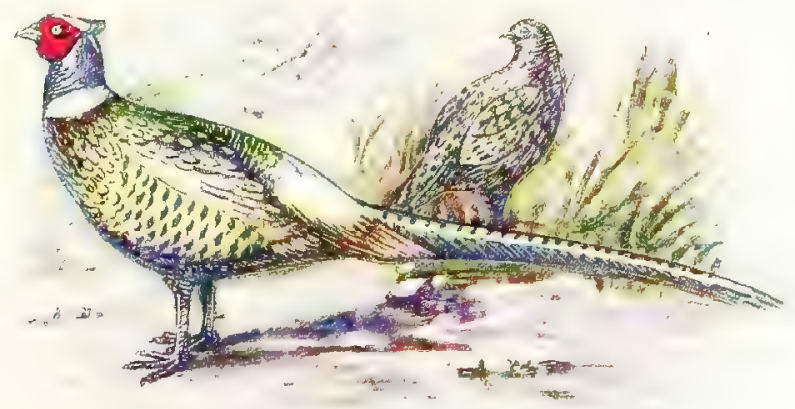




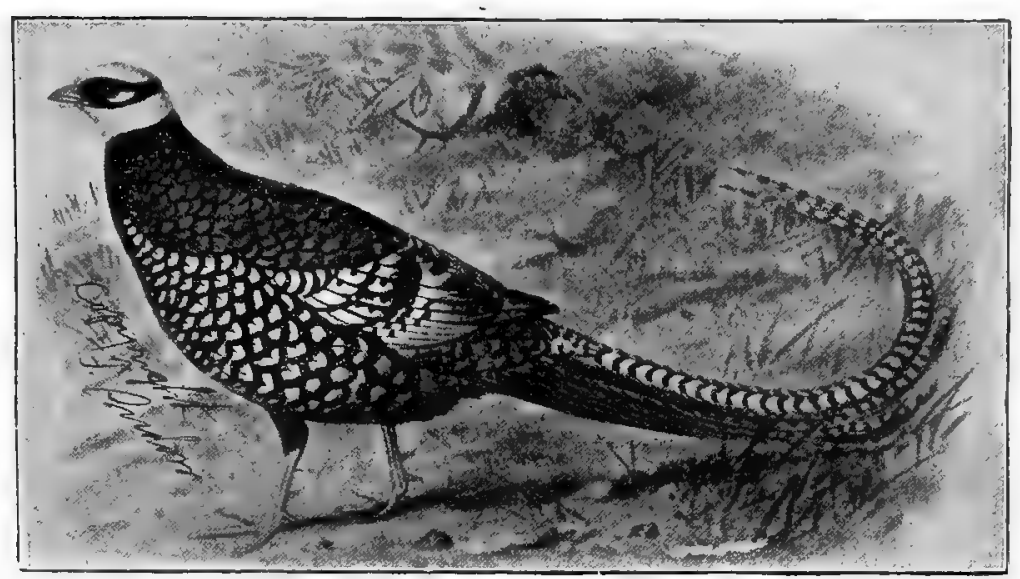

REEVES PHEASANTS-(Phasianus Reevesii). Adapted to covert

These birds originate from China. Their flesh is very delicious and to a great many people superior to that of any other pheasant. The head is covered by a hood of white surrounded by a band of black. The eye is red with a white spot under it. The neck has a broad ring of white; the feathers of the back and breast are of brilliant golden yellow, margined with black. The tail is formed of eighteen feathers, which are closely folded together, so that the entire tail appears narrow. The color of the tail feathers is grayish white, edged with crescent shaped bars of black. The longest tail feathers of this bird are six feet in length. The hen is a rich brown of various shades with a lighter streak of brown under and over the eye. Their weight is from four to six pounds each. The eggs are bluish brown, similar to those of the Mongolian pheasant in color.

It would be impossible to speak too highly of these noble birds-they are truly majestic. There is very little trouble attached to the rearing of them. For a game preserve, they are unequaled and breed as easily as the common pheasant. hen averaging from fifty to sixty eggs in season. They cover their eggs with grass. These pheasants do not crow like other pheasants, but make a singular calling noise and chuckling, repeating the same note about ten times, quite musically but not loud. They obtain their full plumage the first year. The Reeves will cross with Ringnecks and Japanese. They are very quick on the wing, rapidly attaining a good height in the air, giving good rocketing shots. A wide range of hilly country is best suited to the Reeves pheasant. The Reeves in flight is a wonderful sight to the eye and one not easily forgotten and also as an object of aim to the sportsmen. The naturalist knows no grander bird. The male bird displays his plumage by swelling up and drawing in the head as though ready to burst, and then jumping stiff-legged in a big circle around his hen, his long tail being held almost straight up.

Keep the soil in pheasant yards well loosened along the wire fences in order to prevent the birds from getting sore and callous feet as they are walking all day long. 


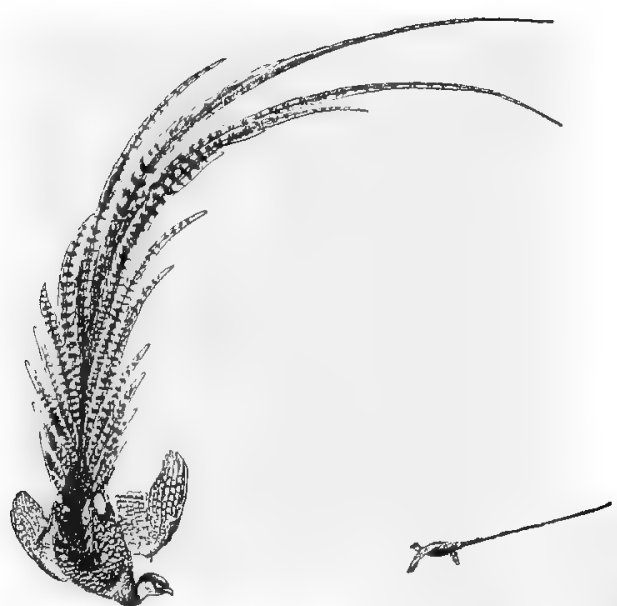

Reeves pheasants have the power to stop suddenly when traveling at full speed which is nearly double that of an ordinary pheasant. This is accomplished by an extraordinary movement of his tail when he desires to alight on some high tree. The illustration gives you an idea of the bird in flight. They travel in flocks of twenty or more and present a bewildering effect when they rise in such a company.

It would be impossible to speak too highly of these noble birds, and those who have room will find but little trouble rearing them.

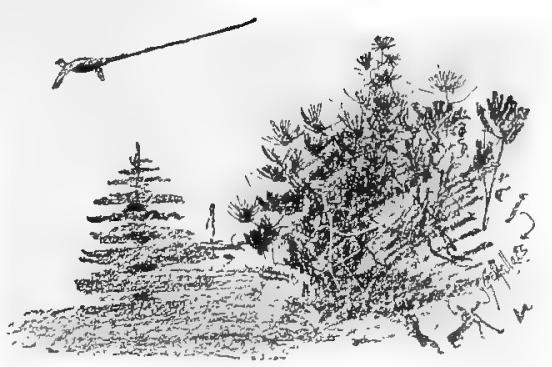

REEVES PHEASANTS IN FLIGHT

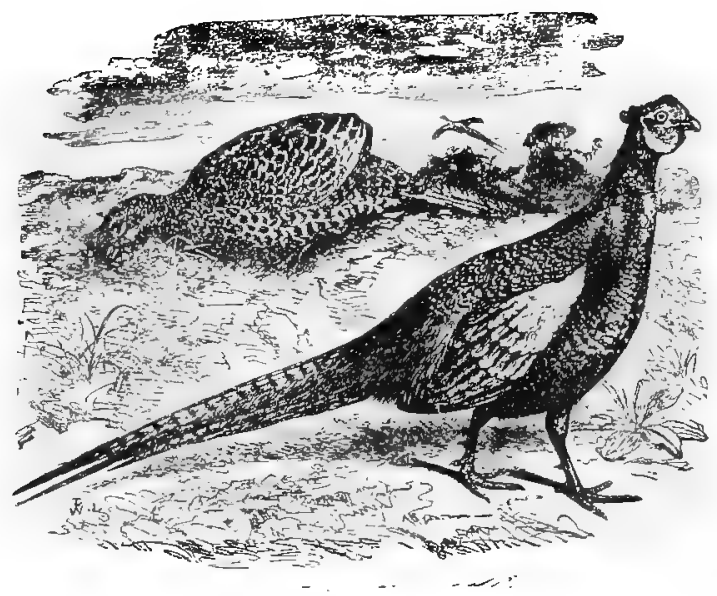

JAPANESE PHEASANTS. (Phasianus Versicolor)
The Japanese pheasant is a native of Japan and is also well adapted to covert. It is doubtful whether any other pheasant magnificent as most of them are, can surpass this bird in brilliancy. The wonderful grass green of the breast, the dark blue of the neck and brilliant scarlet of the face, together constitute one of the most effective combinations of colors to be found in the whole class of birds. In form, habitsand disposition, the Japanese pheasant corresponds closely to the common pheasant. As a game bird, it is both in the covert arrd on the table, of undeniable excellence. The hens are most abundant layers, frequently yielding as many as forty eggs in

season. The coloring of the cock bird shades off onto the neck into metallic blue and green; shoulders similar to the common pheasant; under part of throat and breast rifle green; tail, dark brown mottled with buff and black on edges. The hen is of a rich brown with dark arrow shaped markings. In weight, they average from two and a half to four pounds per bird, as do the Chinese pheasants. 


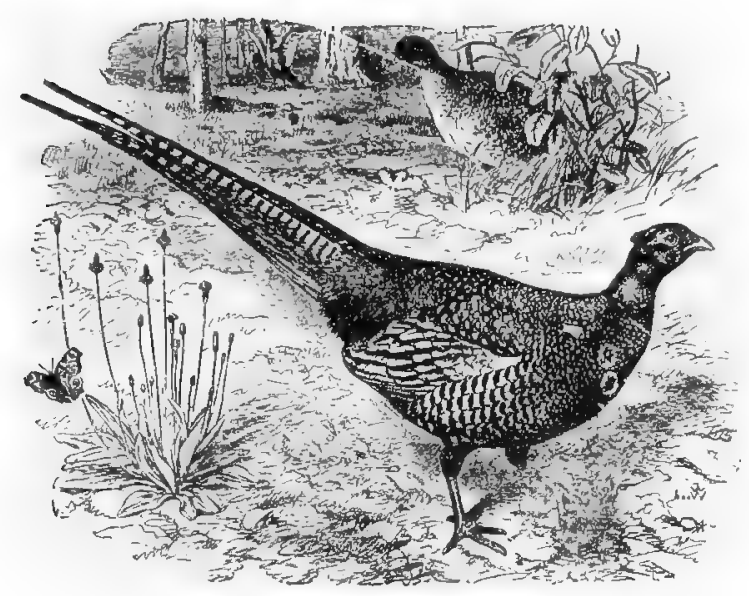

BLACK NECK PHEASANTS

The Black Neck Pheasants resemble the Chinese in plumage and size, but have no white ring around the neck. Excellent breeders. Hen averages eighty eggs in season." Season April till August. Weight about three lbs.

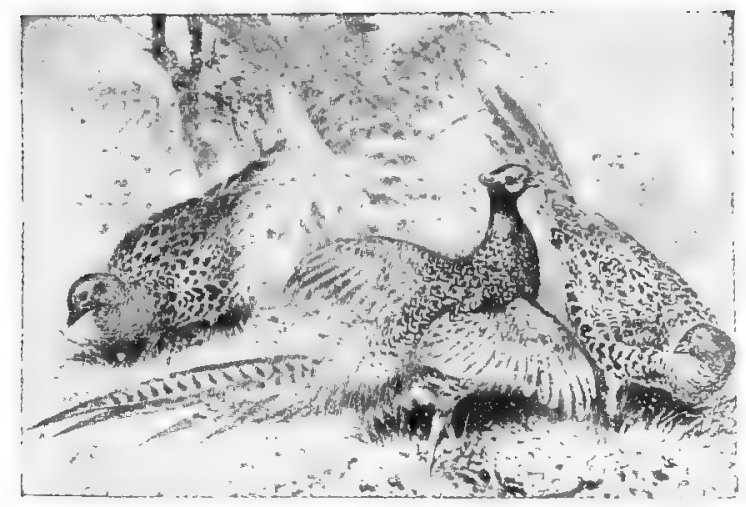

THE COMMON PHEASANTS

The birds are fine table delicacies and are largely planted to-day in the State of Oregon. The male has a purple neck glossed with green, a long pointed tail of olive color barred with black and fringed with maroon. Hen of mottled brown. They are very strong on the wing, hearty and well fitting for the covert, fine breeders. Hen averages eighty eggs in a season-March till August. Average weight about three 1bs.

Common Chinese, English and ringneck pheasants, when running at large, multiply again as fast as quail. A hen will raise from 35 to 40 young in a season. The chicks are known to leave their mother as early as three weeks old. We have to-day game preserves in England where as many as 5,000 pheasants are shot in a season. All varieties of pheasants breed the first year, but two and three year-old birds breed much better. The breeding qualities last from twelve to fifteen years. 


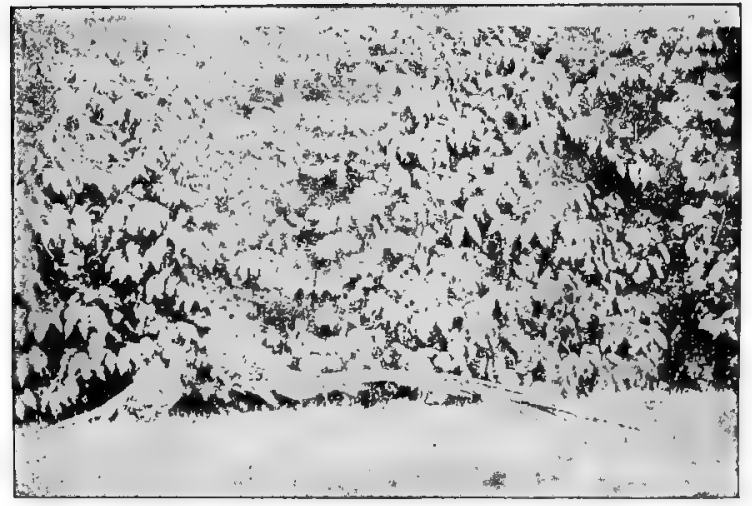
do not want to be annoyed. The plumage is of very brilliant golden yellow. The feathers are very valuable for millinery purposes.

\section{Reeves Pheasants}

They render an ornament to any estate and are game birds of great sport. Lord Marjorbeak has a game preserve stocked with Reeves' pheasants in England and as many as nine hundred (900) are shot in a season, affording very fine hunting. The meat of these birds is delicious and excellent for the table. The birds are very hardy and stand any climate. They will stand confinement well, but require a good sized yard, and

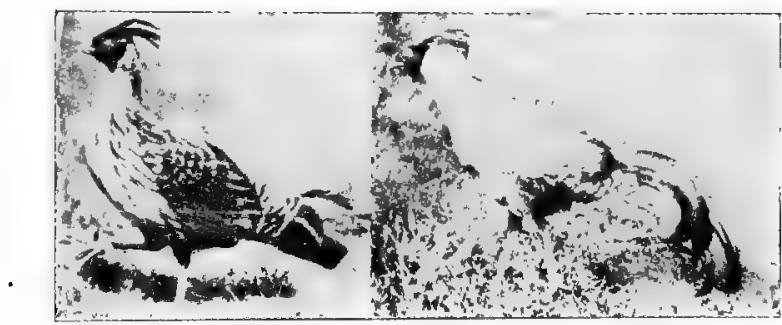

MELANOTUS PHEASANTS SIAMESE PHEASANTS

\section{Siamese Pheasants}

They look similar to the silver pheasants, excepting the saddle is yellow, shaded into brilliant red and orange. These pheasants are extremely rare, natives of Siam. It is said they will breed in confinement but very poorly. Hen average about fifteen eggs in season. Weight about four lbs.

\section{Melanotus Pheasants}

This is a striking looking bird, big and heavy set, equaling a medium size fowl and is clothed in a peculiarly loose texture, well adapted for defending itself against severe weather. The specie has a black, velvety cap and white throat, the plumage is of light steel blue, tail feathers quite long and bushy. They are good breeders, the hen averaging twenty-five to thirty eggs a season, April-July; weight about three lbs.

\section{Mongolian Pheasants}

(Phasianus Mongolicus). Also adapted to covert

The magnificent pheasant known as the Mongolian, comes from the valley of the SyrDaryr and as far east as Lake Saisan. It is characterized by a broad white ring around the neck; breast, bronze-orange red; throat purple bronzy red. It is exceedingly hardy and suffers more from extreme heat than severe cold. They are prolific breeders, the hen averagaging fifty-five eggs in a season. When full grown, they weigh from three to seven pounds each. 


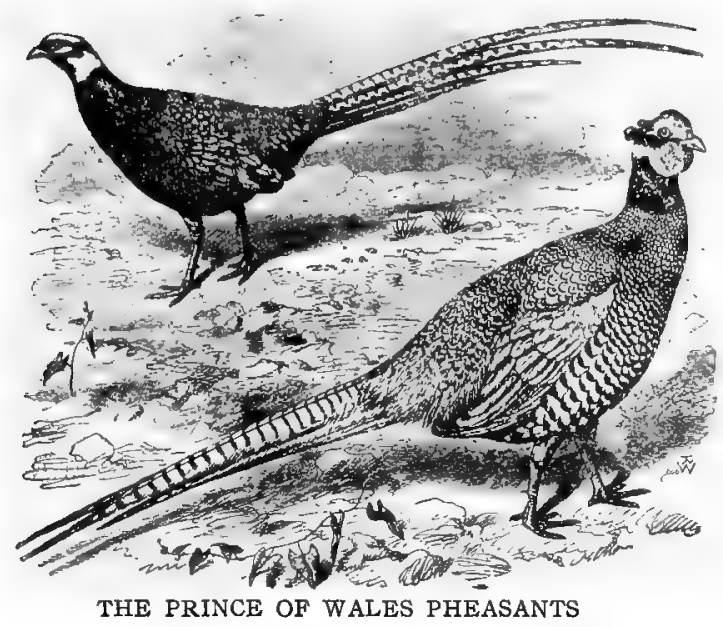

The wing coverts are white, the plumage is beautifully spangled with light purplish black and a rich golden red ground. The bird has very little ring around the neck and a splendid breeder like the Chinese pheasant. Average weight, three lbs.

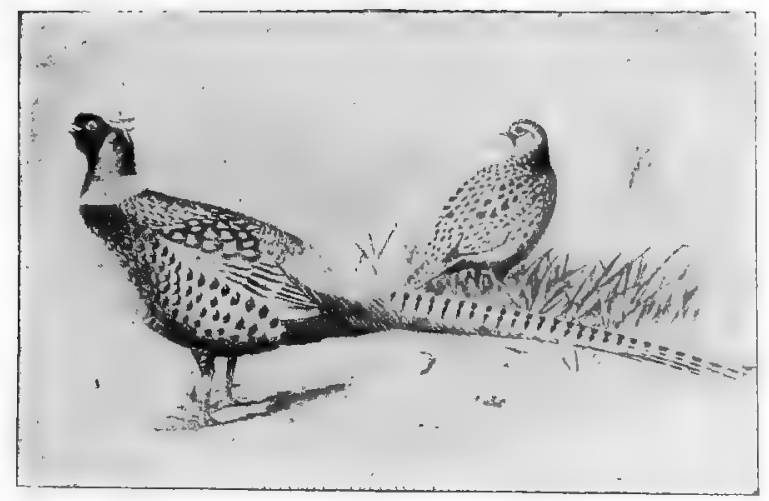

HAGENBECK PHEASANTS-Adapted to covert

This bird is somewhat allied to the Chinese, but a larger frame. The feathers have a creamy white ground color. The lower back and rump is of a very mottled appearance, and wing covers blue-grey. The front, neck and the sides are oily green. They are prolifie breeders, hen averaging fifty eggs in season. The eggs are light brown in color. Thesc pheasants weigh from two and a half to four pounds.

\section{All About Tails}

If a pheasant gets sick, pull the tail out; it will help to save its strength. If a pheasant cock is too vigorous and active and inclined to fight or be bossy, or act cruel to the hens, pull the tail out; it will take considerable of his proudness off. If you ship pheasants it is a good idea to pull part of the tail out it is apt to become raggy in the coop break off and be left in that condition; whereas if pulled out a new tail will grow in a few weeks and the new owner will appreciate it.

If you want your pheasants to look silick pull part of the tails out twice a year. 


\section{A Pleased Customer}

Mr. Ferd. Sudow.

Rowlesburg, W. Va., March 16th, '09.

\section{Dear Sir:-}

I received my pair of golden pheasants yesterday morning in good shape, and I am very proud of them, I want to thank you for sending me such a fine pair of birds. I believe if I had charged everybody $10 \mathrm{c}$ that looked at them I would have made $\$ 15.00$ yesterday. They seem to be very happy in their new home. Again thanking you for the birds, and wishing you good success in your business, I am,

Yours truly,

Oscar B. Buckner.

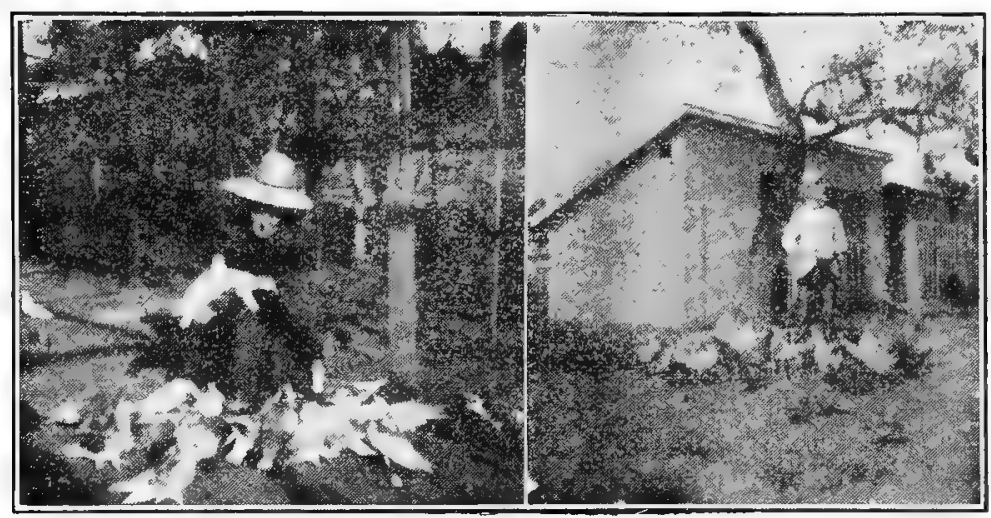

Mr. and Mrs. Ferd. Sudow, two enthusiastic lovers of birds, Taken in 1897, when we made our first attempt in the poultry and pigeon business.

\section{The Law Permits Keeping Pheasants Game Birds, etc., in Captivity}

State of New York, Forest, Fish and Game Commission

Mr. Ferd. Sudow, Albany.

Poughkeepsie, N. Y.

Dear Sir:-

Referring to your letter of recent date, would state that we have granted permission to people like yourself who wish to use game birds for propagation purposes, and as long as the same is not reduced to food we do not consider that you would be violating the game law.

Very truly yours,

$$
\begin{aligned}
& \text { James S. Whipple, } \\
& \text { Game Commissioner. }
\end{aligned}
$$

According to this statement, the law allows keeping pheasants and other game birds in captivity for breeding purposes, and I believe this permit holds good for all other States. 
A few of the thousand testimonials of my patrons who read the second edition of the Reliable Pheasant Standard.

\section{F. Sudow:}

U. S. Department of Agriculture, Washington, D. C.

Your Practical Guide, etc., on pheasants should meet the needs of all who are interested in the breeding of pheasants and other game birds.

F. Sudow:

Point Breeze, Sheepshead Bay, L. I., N. Y.

I am pleased to get such a valuable book. I got more out of your valuable book on pheasants (how to build pheasant yards and how to raise them) than I read in all the poultry books. You are right; there is no comic opera talk in your talk. I have bought all kinds of books on such work, but yours is the first one which I consider a genuine instructor.

Captain George Ayres.

Ferd, Sudow:

Canada.

Your pheasant book received. I have looked it over three times and must say it is way ahead of anything in its line that $I$ have read. From my many years' experience with pheasants, it is easy to see that your method of handling them all through is first-class, inexpensive and can hardly be surpassed. Your hawk, cat, mink, etc., protection is perfect and wonderful. I thank you for this beatiful and instructive little work, worth 100 times 75 cents to me. Yours sincerely, Herbert Gardner, Game Warden.

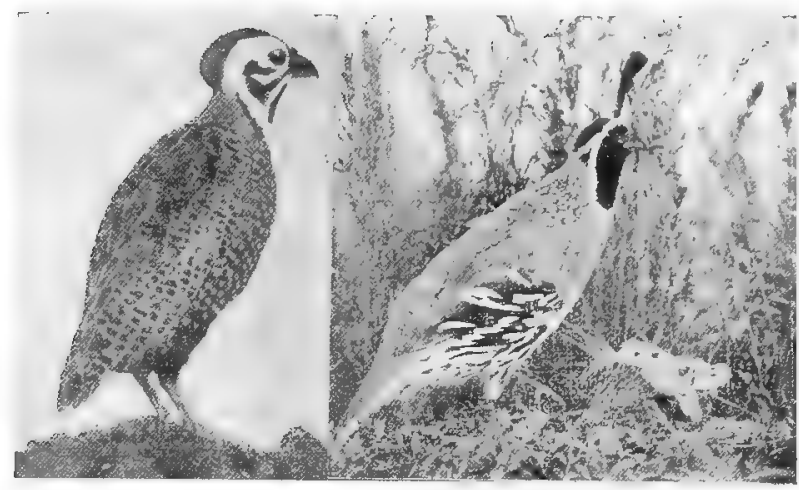

MESSINA QUAIL

CALIFORNIA QUAIL

Ferd. J. Sudow:

Dear Sir:-

Evanston, I11.

I received your valuable pheasant book of recent date. Allow me to congratulate you sincerely for the immense amount of highly useful and practical information you have condensed in this little book. Up to this day, I have read a number of books on pheasant raising, having paid as much as $\$ 1.50$ for one. This being the only practical pheasant book of them all I have read. It appears to my eyes a veritable bijoux and it is. I did not expect to have for only 75 cents such amount of practical and honest information.

Breeder of High-Class Pigeons.

I am yours truly,

Chas, B. Eiden. 


\section{Mandarin and Wood Duck Breeding The Real Duck Bantam Family}

The mandarin duck is the most gorgeotus in appearance of all the ornamental duck tribes, and deserves greater attention from breeders and exhibitors than it has heretofore received. The bird is of small size, weighs about one pound, closely and neatly built, and the beautiful

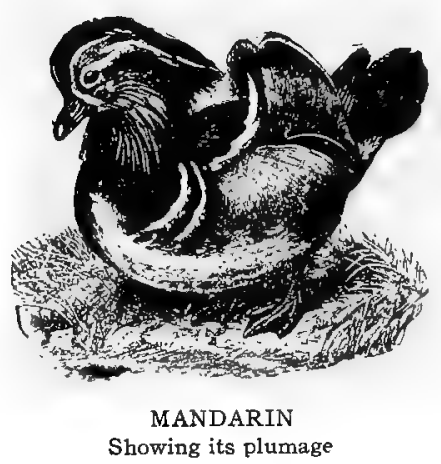
bright plumage of the drake in grandeur, is almost beyond description. The long crest on the head and the fan on the back can be raised or lowered at will. The color of the feathers run in orange-brown to an olive brown and greenish orange. Mandarin ducks are a native of China and it is customary in that country to carry a pair of Mandarin ducks in a wedding procession. They show everlasting fidelity to their mates. The breeding season is from April to June The duck lays from fifteen to twenty-four eggs in a season and the eggs hatch within twenty-one days. The young can be raised with bantam hens and require about the same attention and feed as bantam chicks. Mandarins require a very secluded spot in order to make them breed. In captivity they do not want to be seen or hunted up during breeding season, and their nest must not be molested. I have been very successful breeding these ducks in putting up a lot of cornstalks in their yards, which the birds use for their hiding-place.

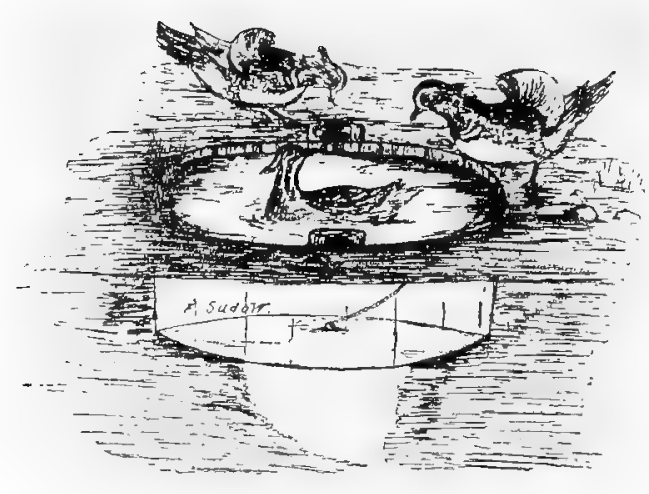

A SWIMMING POOL FOR MANDARIN AND WOOD DUCKS

An aviary should be about the size $6 \times 10$ feet. A good size wash-tub will answer for a swimming pool, and put it in the ground to be even with the surface of the ground, be sure and place this tub in a shady spot. In the middle of the bottom of the tub bore a hole and insert a plug with a chain attached, which will enable you to let the water out by pulling the plug out. In digging the hole for the tub make sure that there is plenty of dirt dug away directly underneath the plug, in order to give the water a chance to soak away readily. The water should be changed every day. The ducks will enjoy this pool immensely and no doubt if you are a lover of birds you will enjoy looking at them. It will also keep their plumage in a most perfect and beautiful condition. To make these beautiful small ducks breed, set some cornstalks in the pen, in which they can hide and make their nests. 
The wood duck belongs also to the bantam duck family and is a beautiful little ornament of exquisite plumage, resembling the man-

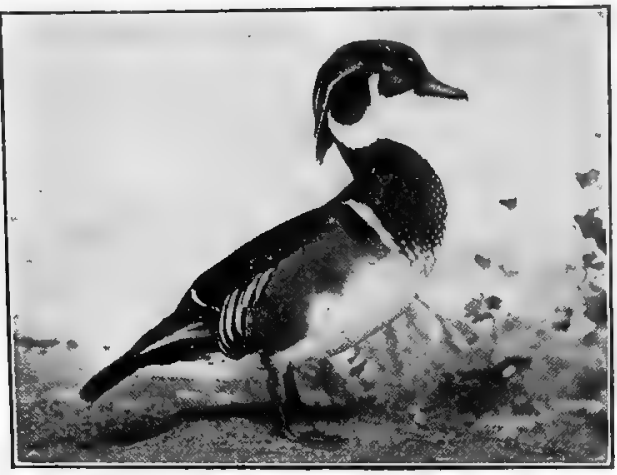

WOOD DUCK darin in its graceful form and size. If you are a lover of birds you will indeed greatly enjoy these birds of never tiring appearance. These ducks require a covered yard same as pheasants. In common with the wood duck, the mandarin will perch and roost in trees and will also breed in the hollows of trees. They can be raised with bantams. but are of use solely for ornamental purposes. There is not much difficulty in rearing these ducks as they appear to be as hardy as the ordinary duck and very little subject to disease. They will eat the same food as required for common ducks.

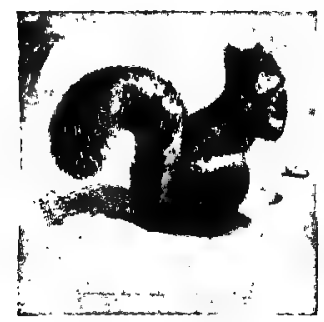

GREY SQUIRREL
Squirrels make very interesting pets, there are eight known varieties; Grey, Red, Black, White, Fox, Flying, Ground and Cimmon Squirrels.

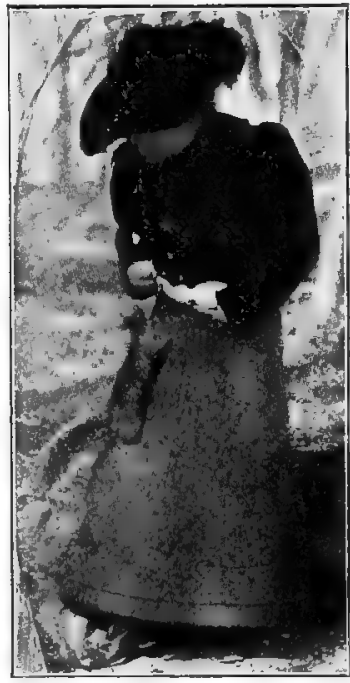

TWO WARM FRIENDS.

\section{A few suggestions and practical hints to my patrons}

Be sure to provide shade for your birds. In order to be a successful pheasant breeder, look for practical points and to those who have already made a success in this grand industry.

Fifty pair of golden pheasants will give a living equal to the average wages of a workingman and at the same time you are your own boss and not a slave to the public. I have raised pheasants for the past twelve years, but have not at any time been able to fill more than half of my orders.

You will surely receive your reward in this world if you are good and kind to dumb animals.

Pheasants are a great attraction for summer hotels. A grand advertising scheme.

Send for my big catalogue and price-list of all varieties of pheasants, wild game, poultry, pigeons,- birds and animals of every description, zoological stock etc.; eggs for hatching cost $20 \mathrm{c}$.

If you want something good to eat, try a pheasant roast. 


\section{Peacock Breeding}

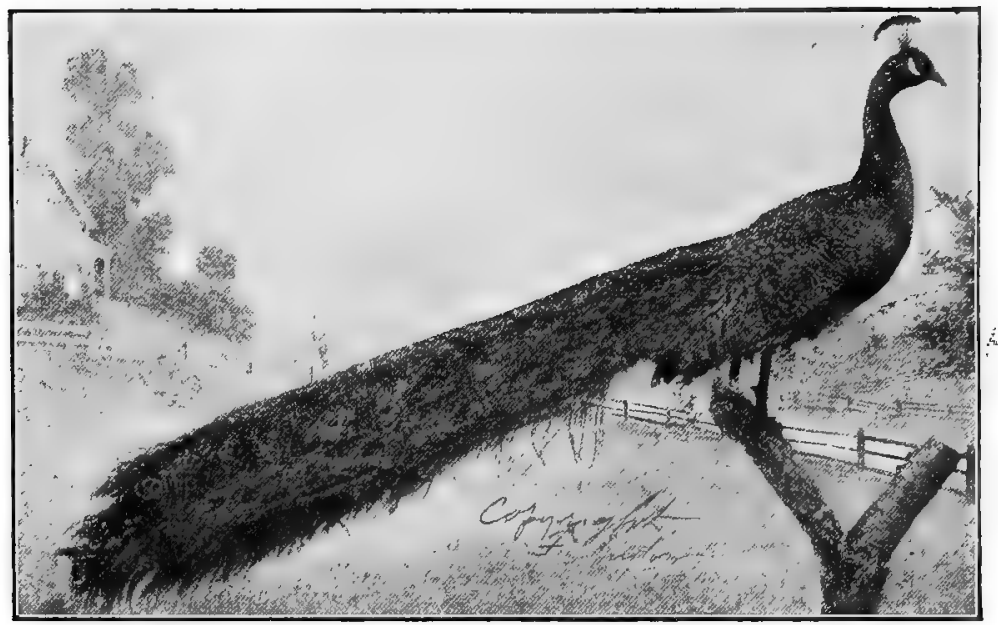

The peacock is well known for its beauty and great attraction. It is extremely easy to manage as its wants are f ew. A n y poultry food is sufficient for t frem. Our ancient forefathers, highly esteemed it as a delicacy. After the bird $\mathrm{h}$ ad been dressed for the table, it was served with the plumage attached and expanded and helped to add to the pomp and splendor of the entertainment. The long plumes of the peacock are valuable for fly-hook manufacturers. The peacock hen makes her nest on the ground and will lay from eight to twelve eggs in Aprit, May and June, setting well and being an attentive and careful mother. The nest must not be interfered with during incubation, which lasts about twenty-eight days. The young are easily raised and of very hearty constitution. They can be fed much the same as young turkeys; hard boiled eggs and stale bread crumbs, or bread soaked in milk for the first two weeks is an excellent feed for them They will stand confinement well. These birds are remarkable for longevity, known to be more than thirty years old.

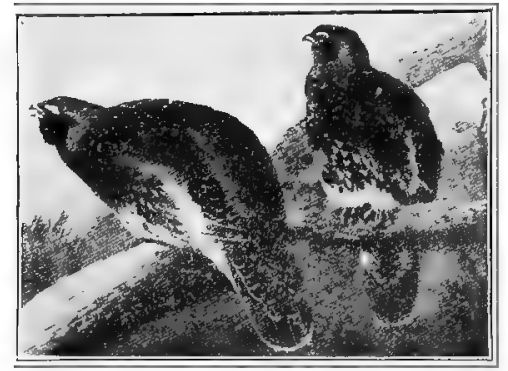

AUERHAHN

\section{Auerhahn or Capercailzies}

These birds belong to the partridge family and next to sage grouse, are the largest of this breed. Full grown birds will measure from forty to forty-five inches in length, and weigh twelve to sixteen lbs. They inhabit extreme cold regions, mostly the mountains in

Europe, and indeed very hardy, averaging about twelve to fifteen young to a pair.

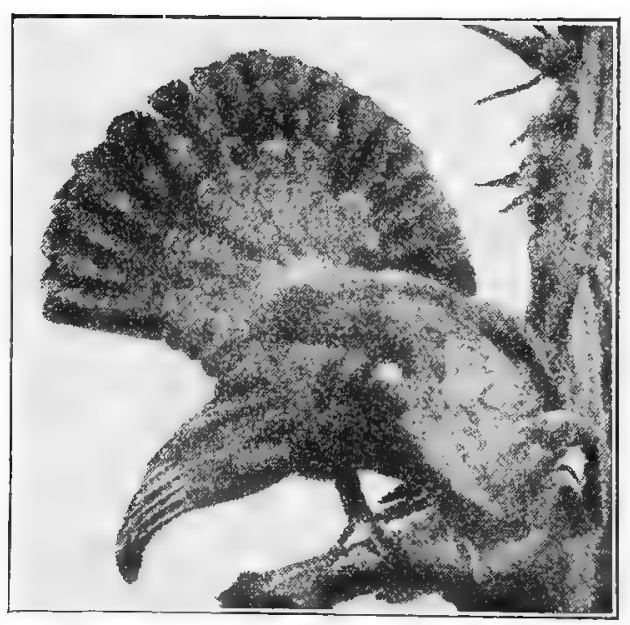

CAPERCAILZIE 


\section{The!Vulturine Guinea Fowl}

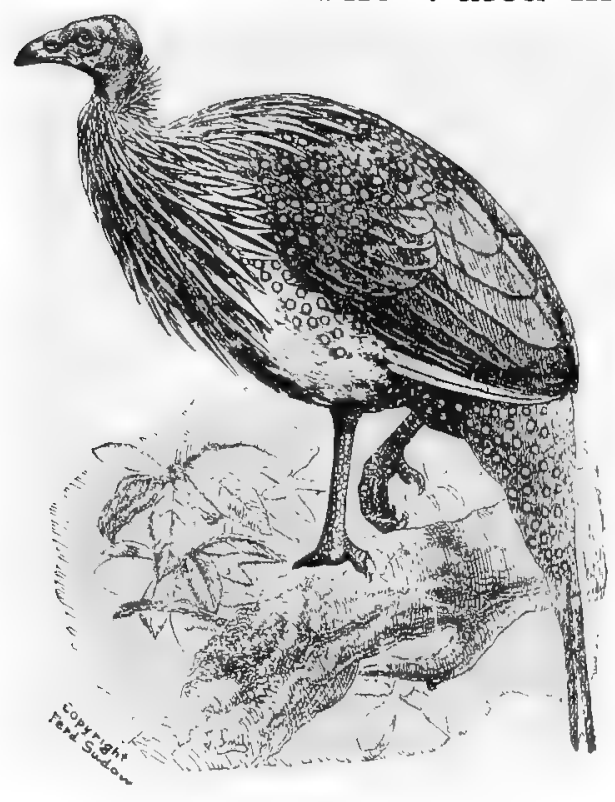

THE VULTURINE GUINEA FOWL

This beautiful bird is rather larger than the common guinea fowl, longer in neck and leg and more erect in carriage. The tail is much longer than the common guinea's, the head has neither helmet nor wattle, simply bare and plain, and the neck and breast are covered with hackles. The plumage is black spotted with white, much handsomer than the common guinea fowl, and the sides of the belly are most beatutiful, azure blue, which color also tinges the hackles at their edges. The wing feathers are bordered with lilac, the head is slate colored, and the legs are black. These birds require warm quarters and good shelter. They will breed in confinement. Hen averages fifteen to twenty eggs in a season. They are certainly one of the most beautiful, unique and desirable birds on this globe for aviary purposes.

Four species of jungle fowl are known, all bearing a resemblance to domestic fowl, a little over bantam size. However, they look more like a pheasant. the tail being kept low. The plumage is like a black-red domestic game-fow1, single comb and of smal size. They will stand confinement well and breed well in April till July.

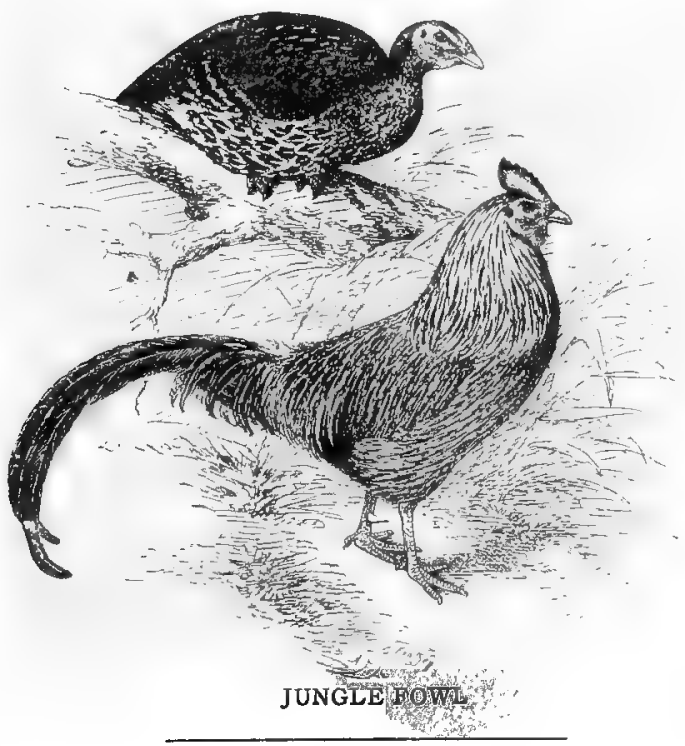

If you want eggs in winter it is absolutely necessary that you should feed cut clover which produces the shell.

For loose bowels feed heavy oats. 


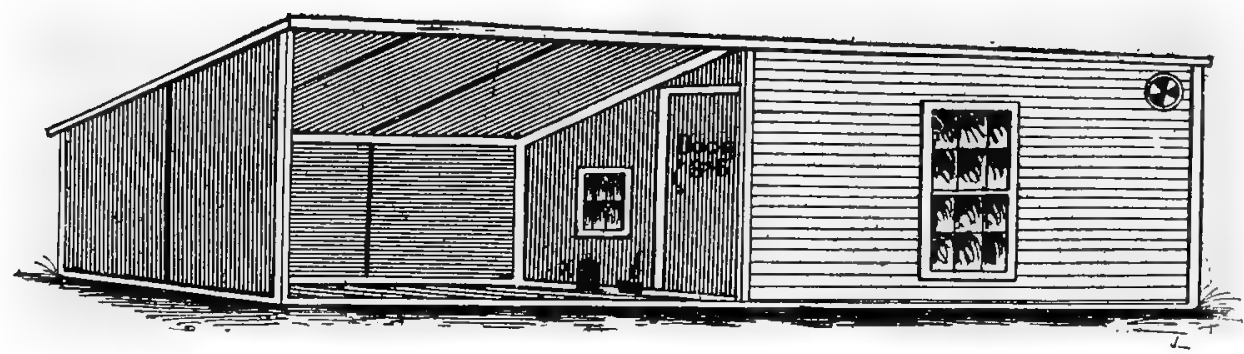

[A PRACTICAL POULTRY HOUSE WITH SCRATCHING SHED

It is a good idea to place 2-inch mesh poultry wire in front of scratching shed, in order to keep the hens under shelter during rough and stormy weather. For scratching feed use small seeds such as canary and millet. Chickens appreciate these seeds as we do our dessert and will work a long time for one kernel.

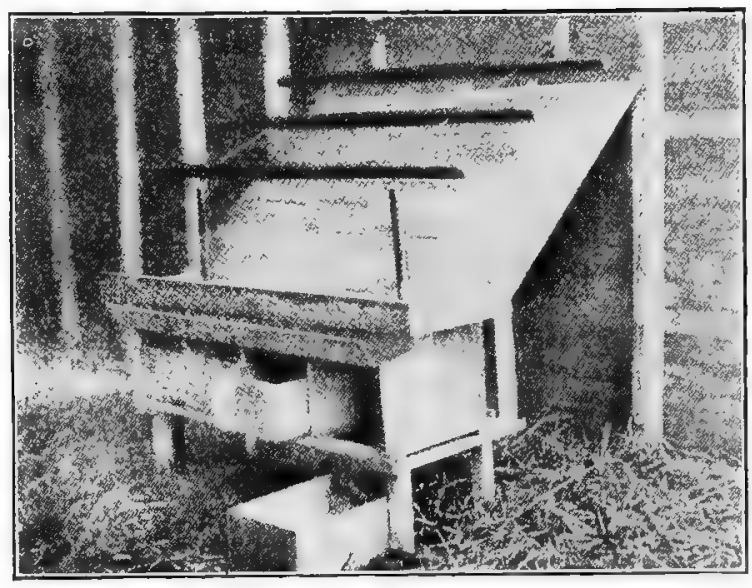

A practical chicken roost. A poultry house should be whitewashed at least four times a year in order to keep "Smarotzers" vermin out

\section{"Sure Egg Recipe"} The Secret to Make Hens Lay all the Year Around, Especially in Winter

Made of the following:

Mix together $20 \mathrm{lbs}$. of ground Corn; 5 lbs. Oats; 3 lbs. of Bran; 5 lbs. Beef Scraps; 2 lbs. Cut Clover; $3 / 4$ 1b. Pratts' Poultry Food; 2 1bs. Oyster Shells; $1 / 4$ lb. Table Salt; use as much as is wanted for one day and add water until moist and crumbly. Can be fed dry also.

Oyster shells and cut clover should be permanentiy kept in a box before the hens.

I have used this feed for a number of years, and I assure you I get more eggs in winter than in summer, and this is no comic opera talk either. The past winter I averaged six eggs from ten hens daily, using the above recipe exclusively. Try it and be convinced. You will also find that eggs produced from this feed have an exceptionally delicious taste, and entirely different from eggs produced from a hen that runs about a dirty barn yard. I consider cut clover a most important feed for a hen's meal in winter to produce egg shells. A customer writes. I used your sure egg recipe and by mistake it was placed before my setting hens, and in three days' time two of them left their nest, quit setting and begun to lay again. This reminds me of another big story I heard. It was recited by an negro through the Edison phonograph from a piece called "My Uncle's Farm," he said there was a spring on his uncle's farm that gave soup; the other fellow had a still better yarn, he said there was a well on his uncle's farm that was so deep if a man was to fall into it, it would take three days' before one could hear the splash. 


\section{A Little Severe Talk on Crows}

Crows are without a doubt the most bitter enemies of our native quail, partridges, pheasants, etc. The story, that severe winters have killed off quail does not hold good; for the reason that our winter weather is not any more severe now than it ever was. The year after the great blizzard of 1888 we had plenty of quall but I believe that crows have greatly added to the extermination of our bob white quail. A wholesale slaughter should be undertaken at once to kill these birds of prey. They are doing great damage to crops, and robbing the farmers of their young chickens. I venture to say crows do damage to crops, poultry, etc., right in Dutchess County, N. Y., amounting to more than two million dollars in a year. From my personal observation I judge about one million crows inhabit Dutchess County. A farmer told me that for the past three years his corn crop was a total failure on account of the crows destroying it, besides robbing him of one half his young poultry. I trust our State Game Commissioner and County Supervisors will in the near future come to the conclusion that something must be done for the destruction of crows. Every farmer suffers to a great extent from damage done by crows. They

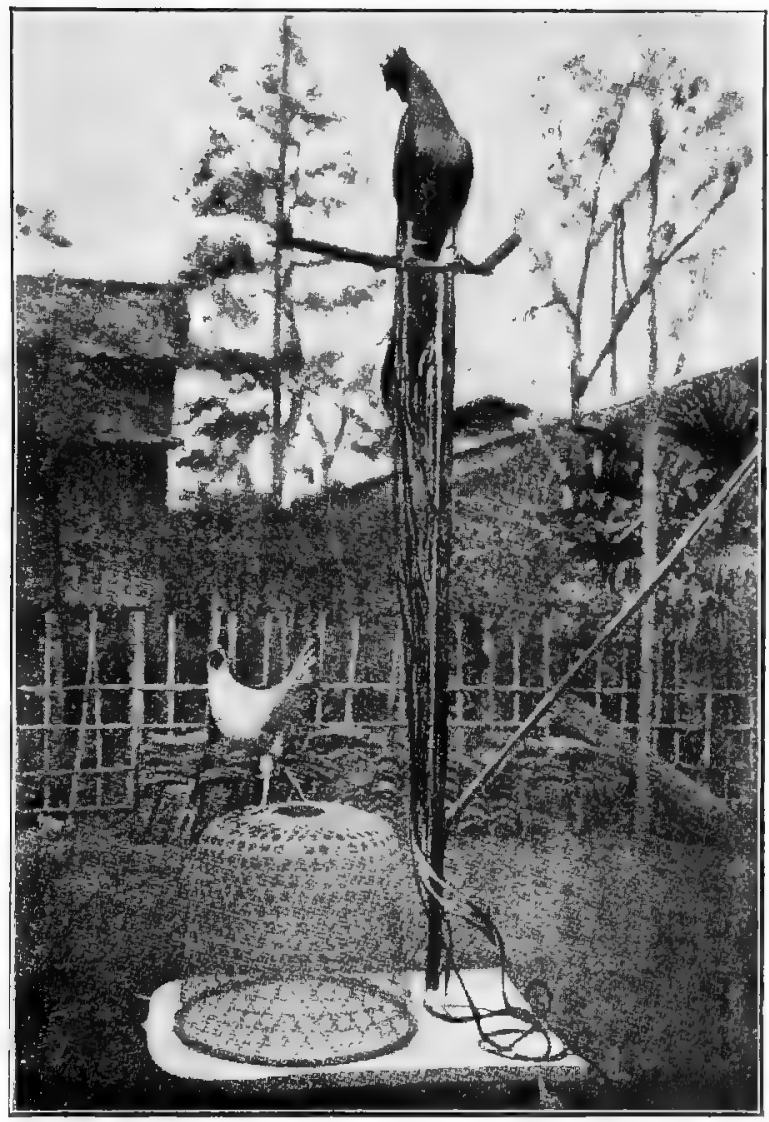
are multiplying at the rate of three to five per pair every year. The slaughtering of these birds should be undertaken during nesting time, by shooting out the nests, and again in winter when heavy snow is on the ground, at which period they congregate in immense large numbers together, and could be killed off in big quantities by a few gun shots. The value of a crow is from $15 \mathrm{c}$ to $25 \mathrm{c}$; for millinery purposes, 


\section{Artificial Nests for Singing Birds How to Trap Sparrows}

These illustrations show how to make artificial nests which are put up in trees for the purpose of attracting and to protect wild singing birds. Thousands of these nests are now put up in the woods throughout Europe, principally Germany and Austria and it is to be hoped that this example will soon be followed in America. Observations are far more effective on this subject than books. The arrangements at Seebach, Germany (the experiment station), which consists of about 100 acres woodland, where over $3000^{\circ}$ of these nesting boxes have been placed and most all of them are occupied, have produced marvelous results in

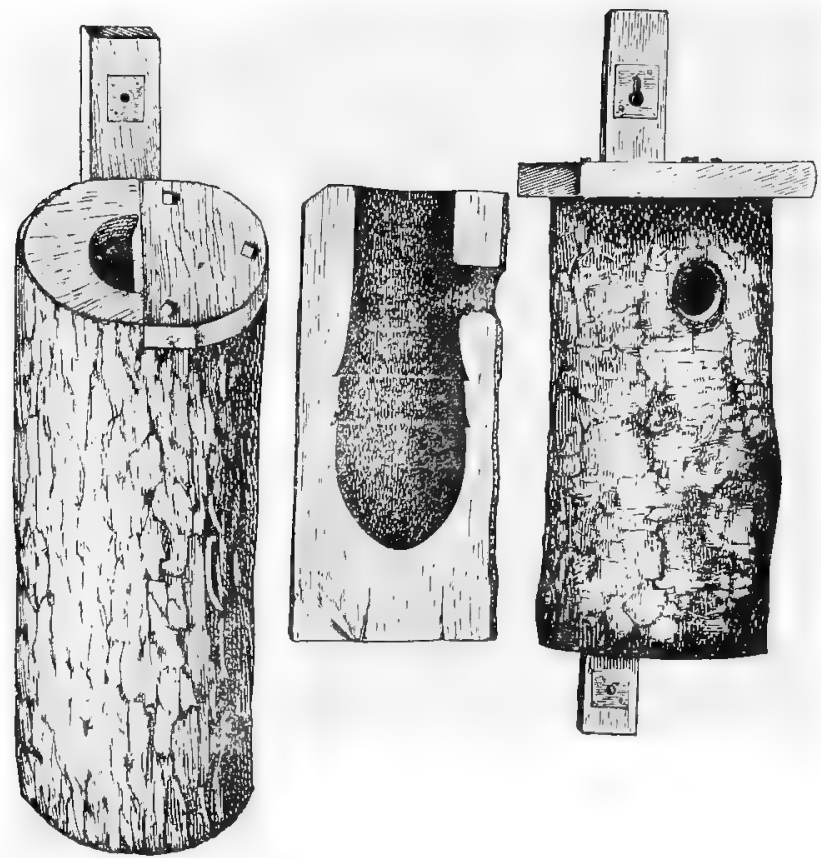

NEST BOXES FOR FINCHES, ORIOLES, WRENS, THRUSHES, STARLING, ETC.

the preservation of singing birds. However I strongly advocate the extermination of sparrows. Do not let them breed anywhere in your buildings. The history claims sparrows originated from England; the truth is they are the true English bulldog of the singing bird family

\section{Sparrow. The Most Bitter Enemy of our Native Singing Birds}

Wherever they congregate no other singing bird their size or even larger can exist. (Sparrows kill thousands of harmless insect eating birds every year.) They do not come under the heading of insect destroyers and are a detriment to the farmer. A good way to exterminate these birds is in the winter when heavy snow is on the ground by trapping them. The best trap that I know of, is to build an off room in a barn or shed, leaving a small opening for a trap door. In this room is placed a lot of hay or straw on the floor in which is scattered cracked corn, millet seed and other grain. 
Upon establishing this trap for sometime and coaxing the sparrows into it for a few days you will be astonished how many you can trap on a cold rough day, when the snow is on the ground. The sparrow being a vary cunning bird will find the feed and tell others very soon. I caught as many as 400 sparrows in just such a trap in a single day. In Europe the boys take great delight in catching sparrows in winter. They are used for the table, offered in restaurants and considered pretty good eating.

RIOHT.
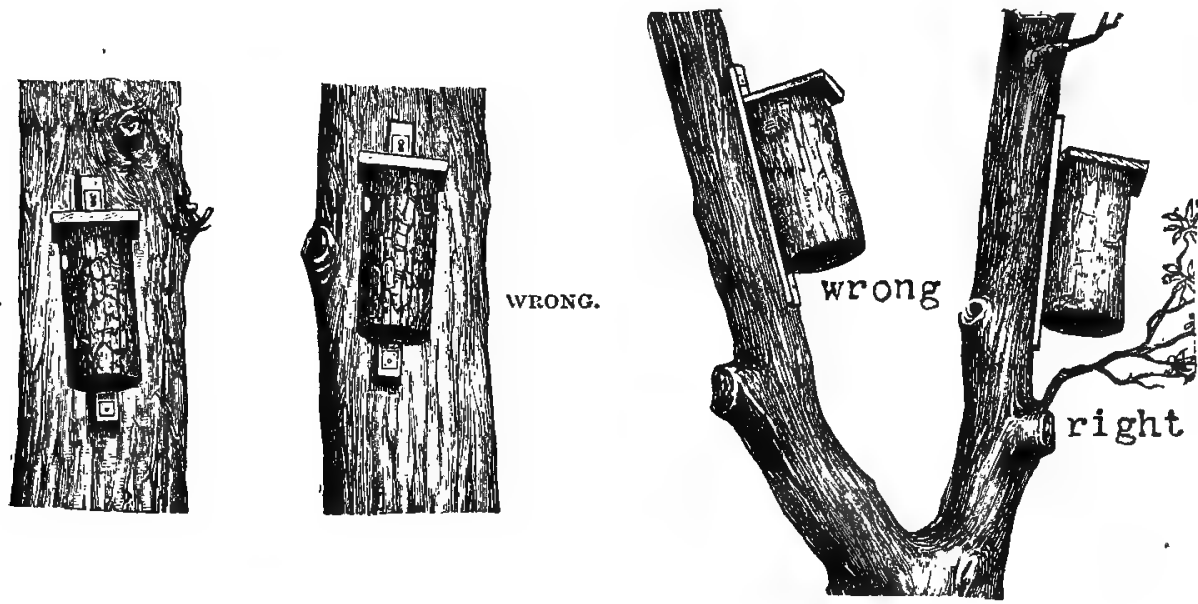

This illustration shows the right and wrong way in putting up nest boxes; place the boxes the hole to face south in such a position so the rain can not drive into the hole any more than possible.

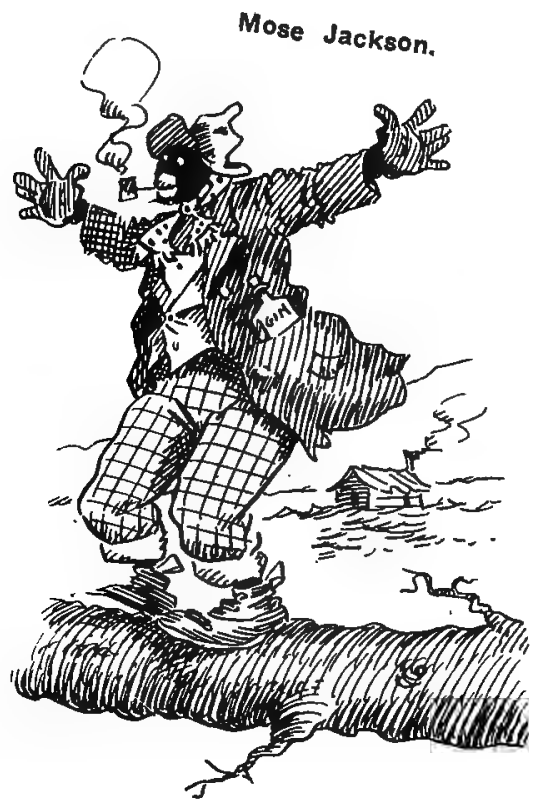

\section{Pheasant Capons}

If you wish to use pheasant cocks for ornamental purposes and overcome their nature as fighters, make capons of them and they will be as peaceable as lambs. It will also enable you to keep hundreds of cock birds in one pen.

What a grand sight to see a large num. ber of them peaceable together

A colored man who for the first time got a glimpse of pheasants-By thar thondarrashon and blitzen, look at dem praty poeasants. 


\section{Hungarian Partridges}

About 15,000 Hungarian partridges were imported into this country in 1908 . They will be the coming game birds of the United States, and will soon take the place of our Bob White quail. They are raised on the same principle as pheasants. These birds are found all over Europe. I shall never forget the grand time afforded me shooting these partridges in Mufrica, a northern Province in Hanover, Germany. They are most plentiful in Austria Hungary where the weather is very hot in summer and extremely cold in winter. Snow covers the ground for four or more months, often up to two feet deep; but in spite of this, these birds thrive well in that part of the country. About 1,000,000 Hungarian partridges are exported yearly from Hungary to go to many parts of the world. In breeding season they pair off like our native quail. During fall and winter the Hungarian partridges live in flocks together, 15 to 25 , and at night assemble in little groups a short distance from each other gathered in a circle with faces turned outward, being always on the lookout for animals and birds of prey. They make their nests on the ground, mostly in green fields or under shelter of brush, the hen averaging from 15 to $20 \mathrm{eggs}$ before she will become broody. A pair will raise two broods in a season. The greatest feature of these birds is that they are absolutely nonmigratory, they are extremely hardy and prolific, and bear confinement well. In size they are more than twice as large as the Bob White quail. For stocking game preserves at least 12 birds should be liberated at the same time They get their living almost anywhere, and on any land and climate and make a most delicious game course for the table. They are best adapted to the covert. I know of no other game bird exceeding them to answer the purpose of training a hunting dog. They lie and hold excellent before a pointer, and are a grand shot for the sportsman.

They measure from ends from head to tip of tail about important point in Hungarian

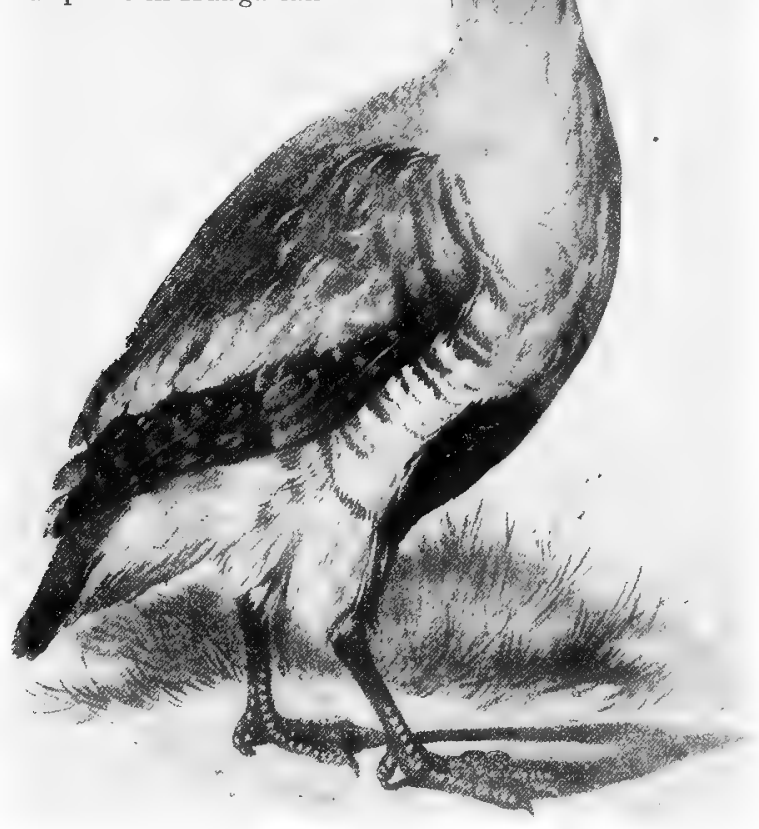

HUNGARIAN PARTRIDGE of wing, spread out 24 ins.; 15 inches long. The most partridges is their hardi. ness and strength. They apparently do not suffer much from extreme changes of heat or cold.

The birds are extremely sociable, peaceable and faithful to one another and they inhabit the same districts the pheasants or Bob White quail do, in fact they have been seen together with Bob Whites and found in the same flock to show that they do not frighten our native quail, but live amiable with them and enjoy their company just the same as with their own kind. As for sport in the field these partridges are more swift in flight than Bob White and ustually lie much closer to cover, giving the dogs a better chance to nose and hold them.

(Continued on page 84) 


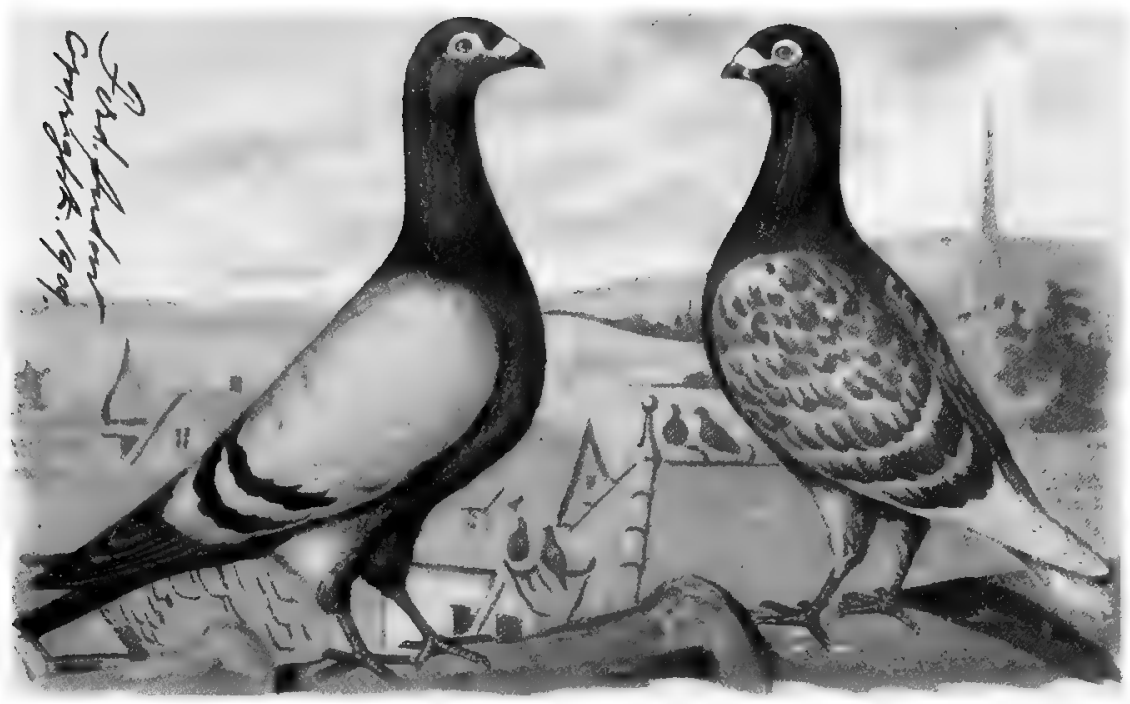

BELGIAN JUMBO HOMERS FOR SQUAB BREEDING AS BRED BY FERD SUDOW

A pair of Belgian Homers raise averaging 14 squabs a year, weighing 9 to 11 pounds to a dozen, worth $\$ 3.00$ net to a breeder. Squab breeding is 50 per cent more profitable than chicken raising with 75 per cent less work. It takes from 21 to 28 days to raise a marketable squab worth 40 to 60 cents, and it takes 90 days to raise and care for a marketable chicken worth 25 to 50 cents. Owing to a new game law prohibiting shipping quail, or keeping game birds in cold storage, squabs take their place on the bill of fare and are in great demand One thousand breeding homers carefully handled will yield a yearly income of about $\$ 1,200$. The cost of keeping a pair of homers, besides nursing their young is about 60 cents a year.

\section{METHOD OF RAISING EXTRA FAT SQUABS. By F. SUDOW. (Copyright.)}

New discovered method forcing squab breeding and raising extra large white squabs; most accurate, harmless but effective pigeon lice killer; how to tell male from female; best markets; quickly and thoroughly cleaned and most practical pigeon nests (illustrated); easiest and quickest way of catching pigeons. Price 25 cents by mail.

You will find squab breeding a pleasure if you use this method. All new ideas; good, sound common sense talk-no comic opera poultry talk at all; no hash. You will never regret having spent these few pennies. It will save lots of trouble and worry.

One thousand enthusiastic testimonials.

\section{BOOKS ON PIGEONS \\ "Pigeons and All About Them"}

Complete book, handsomely illustrated. How to breed and manage pigeons under all conditions. Contains 264 pages, $\$ 1.50$, by mail.

\section{FULTON'S BOOK ON PIGEONS}

Improved, revised edition. The most complete pigeon book published, over 500 pages, fully illustrated with full page engravings. Every fancier should have one of these books. Price $\$ 6.00$.

\section{"IT WILL ADD TO YOUR HAPPINESS"}

Keep Pigeons for recreation after business hours.

Keep Pigeons for your boys, to keep them at home away from bad company.

Keep Pigeons for love of the beautiful, the hobby will add immensely to your happiness.

Keep Flying Homers for racing purposes. It is grand sport and most innocent amusement. 



\section{European Roebuck Deer •}

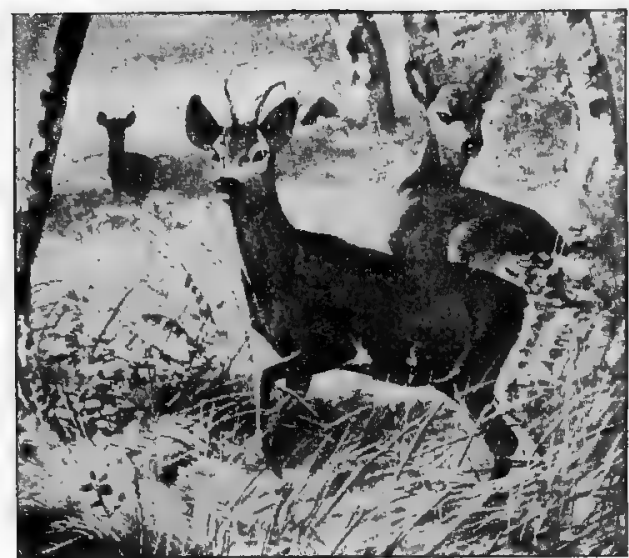

This deer is considered the swiftest game in the world. The animal is found to-day in the northern part of Russia and away down in Italy; adapted for any kind of climate, extremely hardy, weighs from 60 to $75 \mathrm{lbs}$., the size of a large goat, and the meat is very choice, exceeding by far our American lamb. They are very intelligent and genteel animals, and easily tamed to eat from the hand of their keeper.

The doe will produce one or two young every spring and they are as easy to raise as sheep.

ROE DEER-Swiftest game in the world

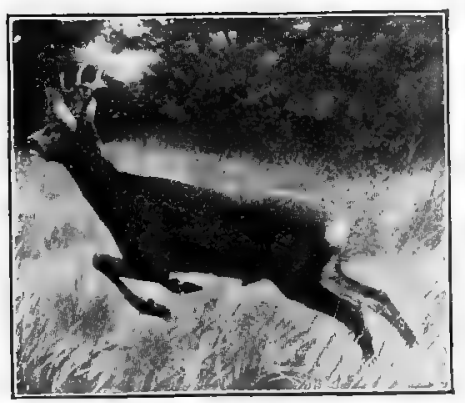

ROE DEER

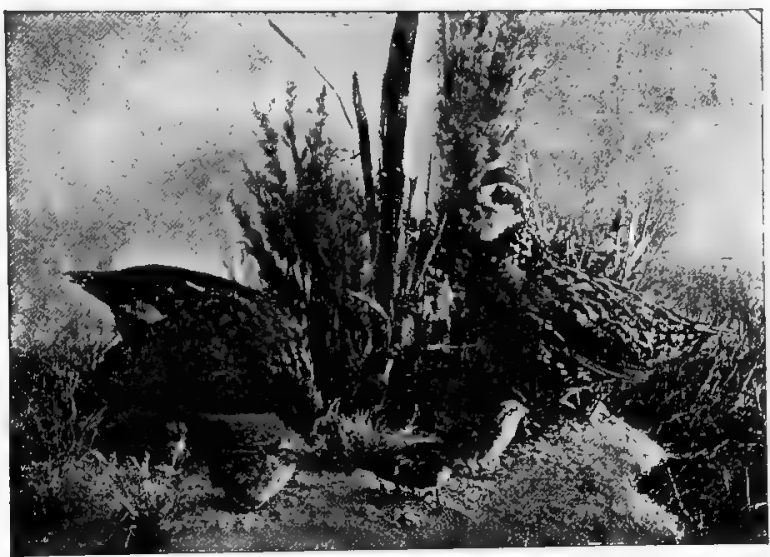

BOB WHITE QUAIL AND CHICKS

\section{HOW TO RAISE QUAIL}

No other inaustry is commanding so much at. tention just now as- Quail Culture, and no other work gives as practical a treatise on the culture as "QUAILOLOGY"

By H. W. Kerr. It gives scientific description and notes on every species from the Bob White to European Quail; 16 page illustrations from livo birds; a practical treatise from $A$ to $\mathrm{z}$ in procuring and raising quail; letters from breeders; and game laws. A valuable work highly commended by the Natural History; Sporting and Fancier's Press of the U. $\mathbf{S}$. Price, postpaid, \$1.00.

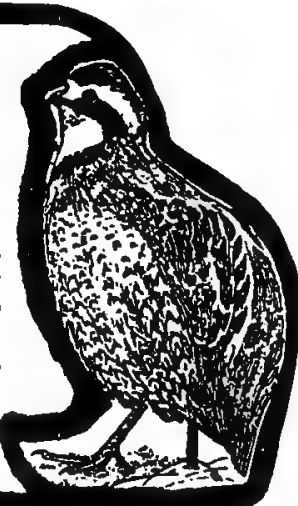




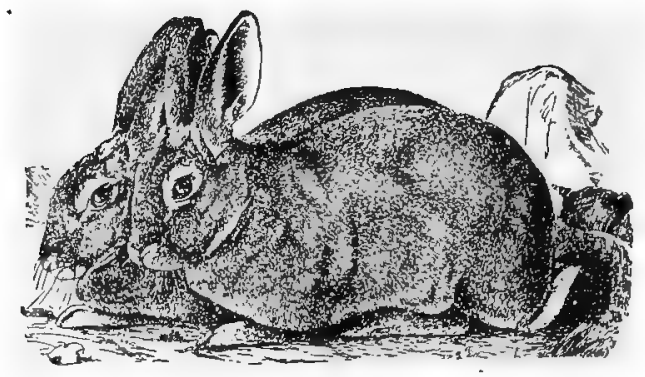

RABBIT BREEDING

The rabbit's period of gestation is thirty days. Most all varieties of rabbits average from seven to eleven young to a litter, but known to have as many as sixteen to a litter. It is an industry in which most any one can engage in to provide recreation, and at the same time provide meat for the table second to none. Rabbit meat is cooked in several ways same as chicken meat, roasted, broiled, fried, etc., and tastes very much the same as chicken meat. It can be produced at a less expense per pound than any other meat I know of, the principal point in breeding rabbits is to protect them from dogs and cats. It is a wrong idea to handle them by the ears. the proper way to handle them is to take a good handful of their pelt right over the shoulders same as you would handle a pup. General feed for rabbits is all kinds of vegetables oats, corn, wheat, rye, stale bread, etc., they will also eat all kinds of weeds and worthless stuff, this makes the keeping very inexpensive. Rabbits best for stocking purposes are the cotton-tail, jack, rabbits, English and German hares. For aviary purposes try he Belgian hares, Dutch rabbit, Lope eared, Angora and Himalayans.

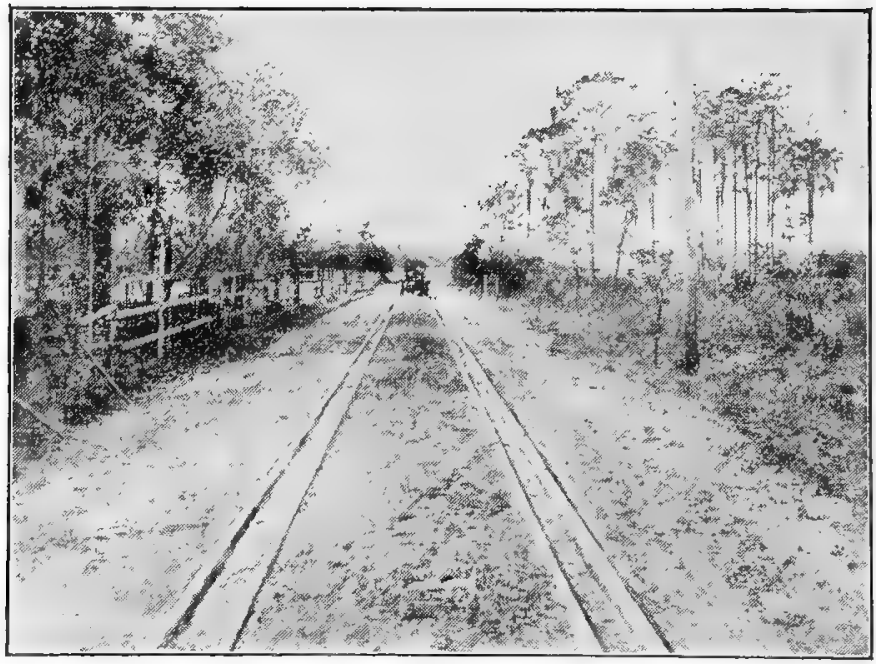

A PRACTICAL CONCRETE ROADWAY THROUGH THE DESERT

An automobile road from New York to San Francisco-or "Bust"- - Let that be the ambition of every automobilist. 


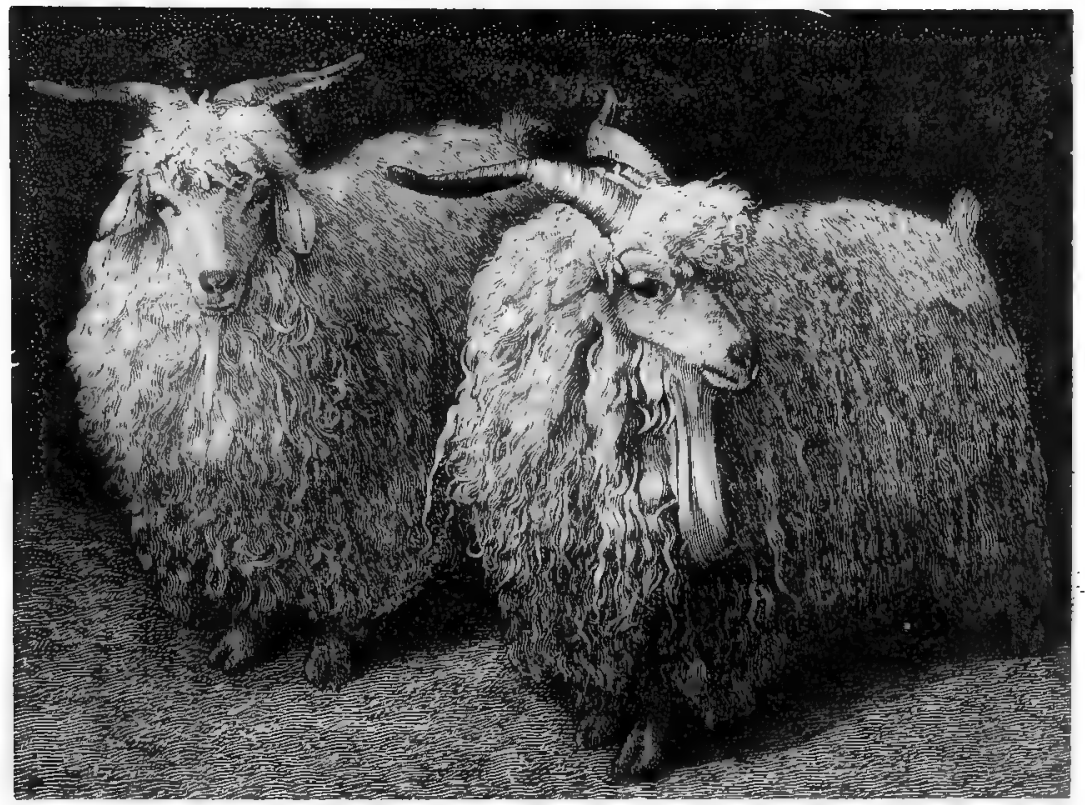

ANGORA GOATS

\section{Angora Goats}

The angora goat is a native of Turkey and the raising of these animals in this country will be one of the coming great industries. One of the great advantages in raising angora goats is the ease and economy with which herds can be profitably handled. They are practically immune from all diseases, and will thrive and prosper where sheep or cattle would starve to death. They are great brush destroyers and will not only clear away the brush better than a gang of laborers could do, but will also get fat in the process. Land which is practically worthless can be made valuable by having it cleared by these goats, who will fertilize it at the same time. A great deal of farmland in Iowa and California has been cleared in this manner. This shows how easy and cheap it is to keep angora goats. They can be raised with profit in any section of the United States.

The angora goat makes an ideal domestic pet. It is intelligent and affectionate and its milk is declared by scientists to be next to mother's milk in value. The chief value lies in its fine wool, which is long and lustrous. This wool is second in commercial value to silk,

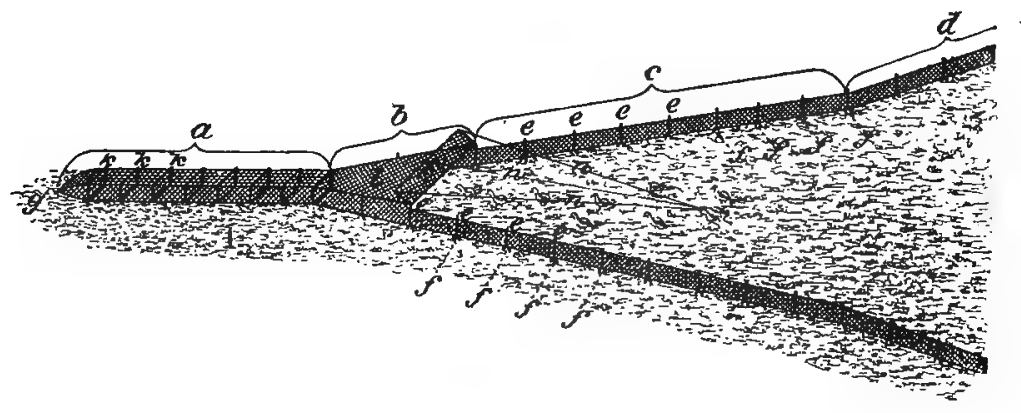


called mohair and also enters into the making of plush goods. The wool brings from twentyfive cents to a dollar per pound and the average fleece of the pure bred angora is from four to eight pounds. The shearing is done in early spring. Angoras are in their prime from two to six years old. When an angora is killed its carcass also has its price in the meat market. There is a growing demand for angora meat. The meat is rich and juicy and free from that strong taste found in the common goat.

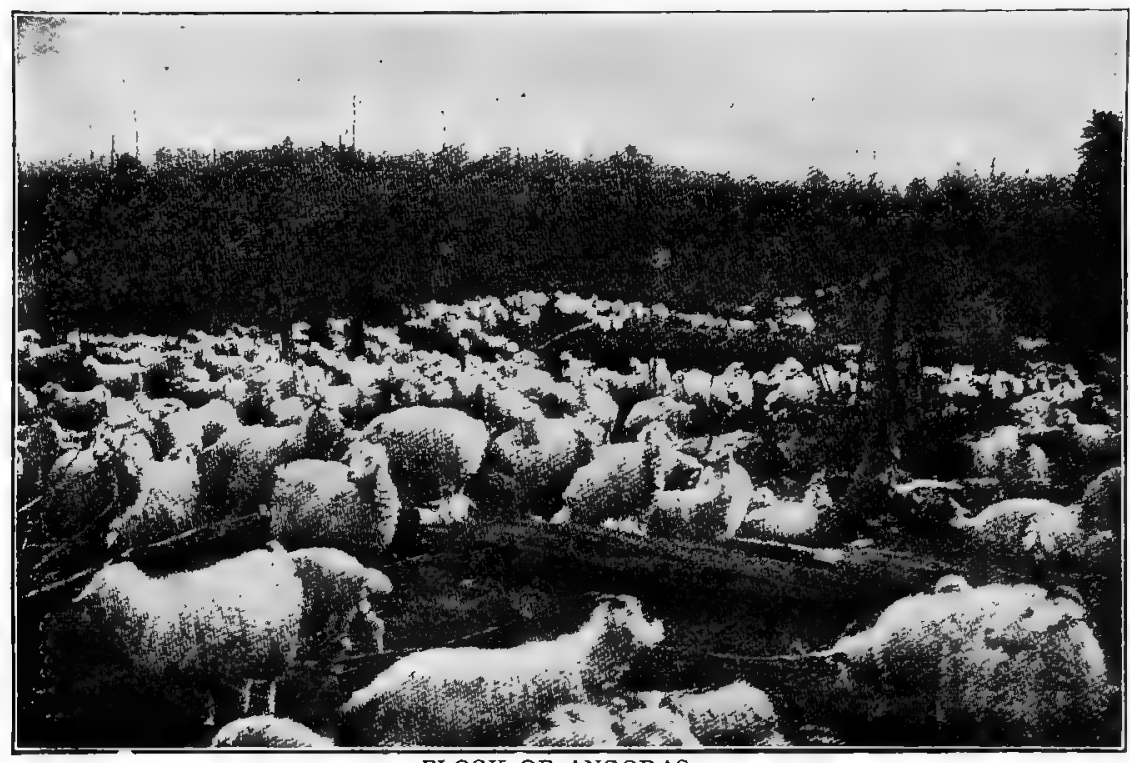

FLOCK OF ANGORAS

Angora goats are very valuable for their mohair and skin, tough nature and live on most anything, great brush destroyers and are reared same as common mutton.

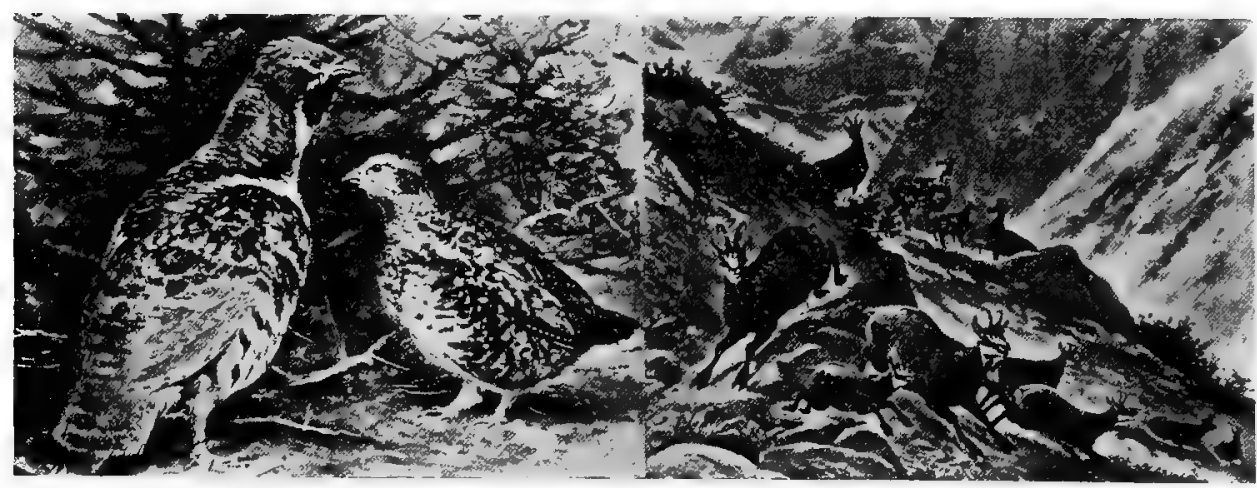

BOHEMIAN QUAIL

SWISS CHAMOIS-From the Alps

Hungarian Partridges-Continued from page 78

Partridge chicks commence to run just as soon as they leave the shell and are very wholesome creatures. The parent birds take equal parts in the care and raising the young. The cock bird guards and shelters them the same as the hen does and they generally rear all of the brood. Young partridges live almost exclusively on insects and worms in their early age. Later on they feed on small grains such as weed seeds, celery tops, apples, bugs, berries, etc., they have a great preference to buckwheat fields, etc. 


\section{Ostrich Breeding}

Within the last twenty years the ostrich has been successfully transplanted to this new world and is now bred in many southern States, California and Arizona, etc. There are some five thousand ostriches at this writing, solely kept for the production of their plumage. The ostrich feather trade now amounts to about twenty million dollars in value annually. A large ostrich farm is situated in Arizona, where some fifteen hundred ostriches are yielding about ninety thousand dollars' worth of feathers yearly.

Every four months the ostriches are deprived of their superfluous finery that adorns them, for the benefit of the millinery trade. The ostrich is a peacefully disposed creat are and its domestication has proven a success. Each bird yields about sixty dollars' worth of ostrich finery every year. As an ostrich is believed to reach the good old age of sixty years, there is a very profitable and steady income in view for the ostrich farmer. The expense of keeping ostriches is about the same as sheep. They live on grass principally. The ostrich is a multiplier, the hen lays an average of some two dozen eggs every season. The eggs weigh about three pounds and a half each and taste the same as chicken eggs.

Of course, they are somewhat an expensive article of food. One will make an omelet for a dozen people. The male and female take turns in setting on the eggs, - the male setting at night when his black feathers are not easily seen, and the female in the daytime, as her plumage closely resembles the color of the ground. If a pair is not allowed to set, sixty or more eggs will be laid in a season.

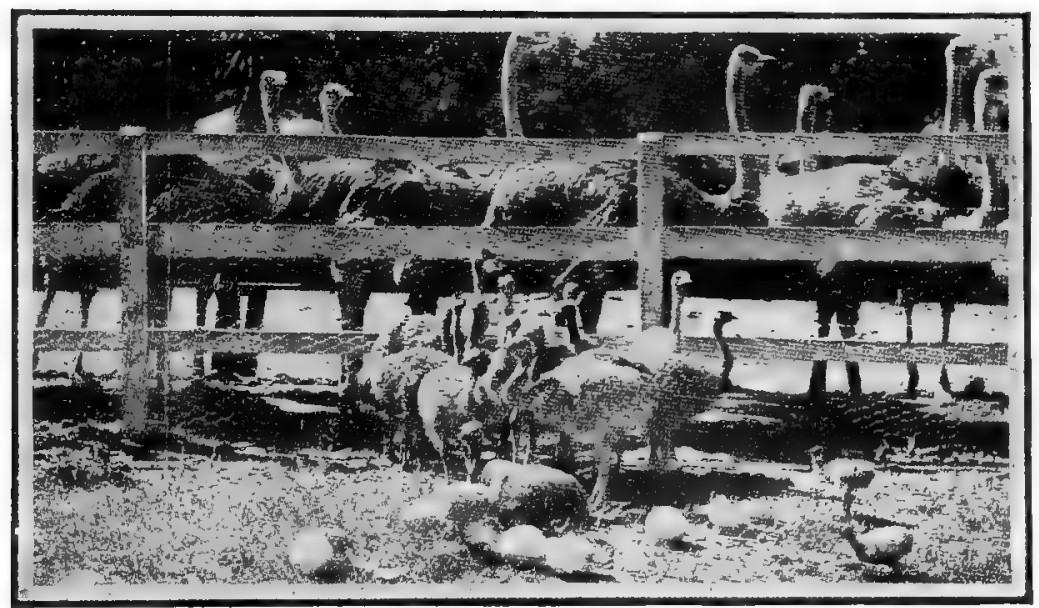

OSTRICHES AND THEIR YOUNG-FROM 1 DAY TO 2 MONTHS OLD

The laying time is February and August. They first proceed to dig a hole in the ground some twelve inches deep; the hen lays 12 to $15 \mathrm{eggs}$ when she will become broody and set down to hatch. Two weeks after she has been engaged in this useful occupation the ostrich farmer removes the eggs to the incubator and hatches them by machinery. It takes almost nine weeks to hatch ostrich eggs. The young are extremely hardy and raised in brooders.

The chicks, when hatched, represent fluffy little creatures with striped, velvety necks and plump, well-shaped bodies. They are about a foot high and grow at a surprising rate. They increase about a foot in height each month until six months old, after which they are full grown birds. 
Ostriches eat corn, alfalfa, vegetables, grass and green food of all sorts. They are, indeed. very greedy and will gobble nearly everything that is offered to them. They require plenty of bones and gravel to aid their digestion.

Ostriches are very fond of oranges and when they are thrown to them, they will catch them in their open mouths and as they raise their heads, the orange can be seen, passing speedily down their long necks. They will swallow most anything. It often happens, while lady visitors are standing too close to their enclosure, a bird will stretch his lonk neck over the fence and grab something from a hat or dress, - sometimes even jewelry-and swallow it eagerly, without any investigation. It is said that even lighted tobacco-pipes have been seized and swallowed before they could be rescued.

Birds intended for breeding purposes are kept separated from those selected for feather raising, single birds producing the best feathers. An ostrich is first plucked at the age of seven months and then at intervals of six to eight months. After being plucked, the feathers are carefully cleaned, sorted and dyed. The beauty of an ostrich feather depends more on its width, and the length and thickness of its strands, than on the length of the quill.

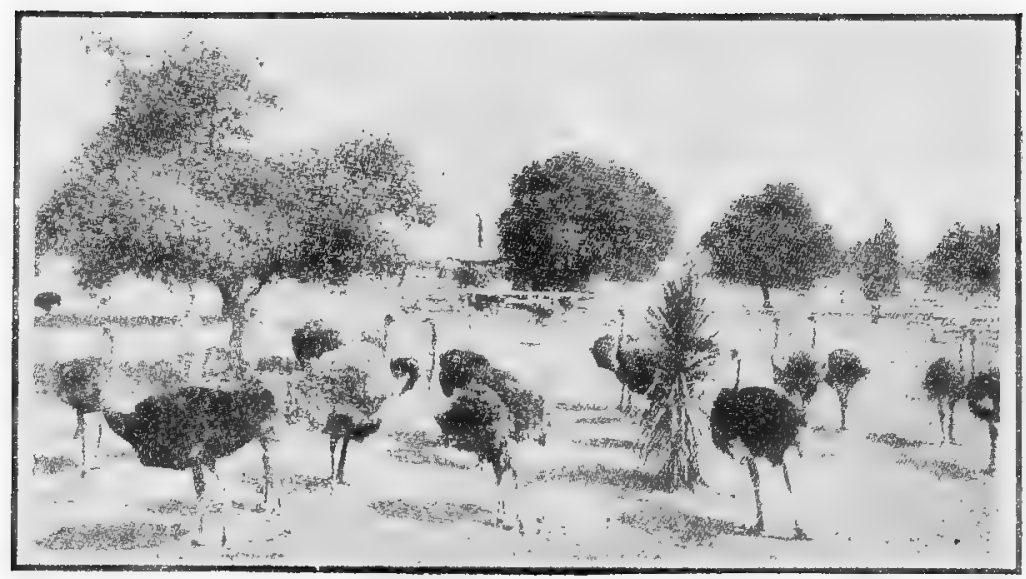

In order to pluck an ostrich, a bag or hood, is thrown over his head after which he can be handled very easily. As a rule, he is led to a solid wooden box, just large enough for him to stand in, and where he has no chance to turn around or kick. They have as much strength as a horse, and if an inexperienced person is assailed by an angry ostrich, the best thing to do is to lie down flat. The ostrich attacks by kicking,-however he cannot kick an object on the ground.

The climate of southern California is best suited to the ostrich. The bright, sunny days are not so blazingly hot as those of South Africa, and a heavier crop of feathers is produced as a natural protection against the chilly breezes from the ocean after sundown.

The American Ostrich Trust in Arizona pays $\$ 600$ per dozen for ostrich chicks, and the American ostrich farmer has no trouble in disposing of his stock. The ostrich industry is an exceedingly profitable one and grows more so every year. 


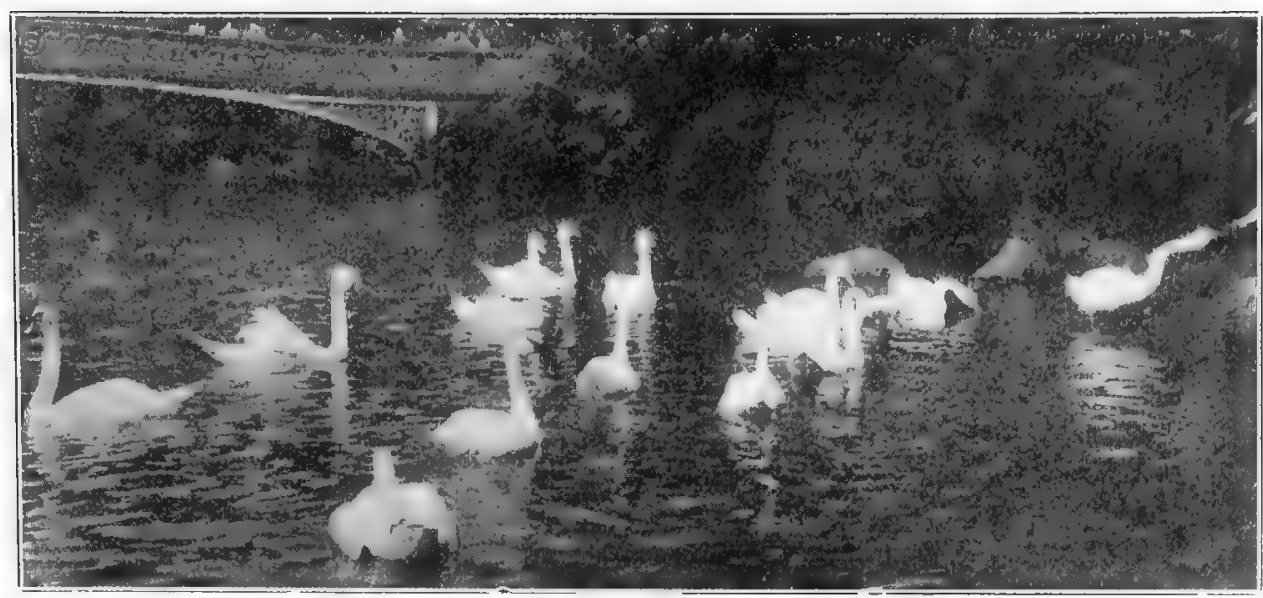

\section{Swan Breeding}

The increasing demand for ornamental birds for parks and country estates is the basis of the interest in swans. Given a suitable location, such as a natural pond, with some wild marsh and meadow nearby and swans are easily raised. They are fond of water, plants and roots. Also of fish spawn, hence should not be kept in a valuable fish preserve.

The beautiful white or black swan is a very large fowl, the pure white being the most attractive both in form and color. These birds are domestic, same as geese, and of extremely

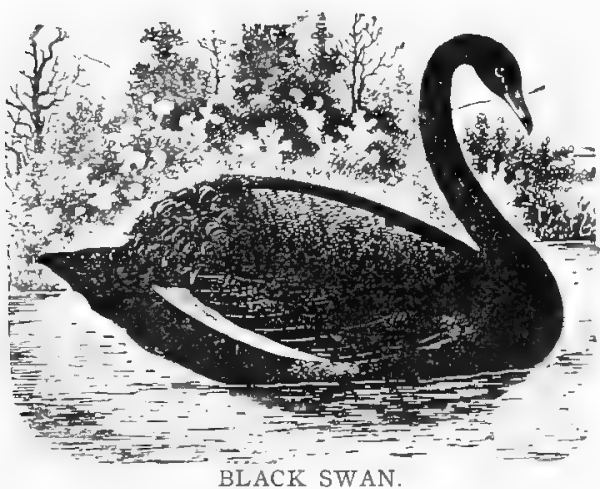
hardy constitution. The nest is built by both male and female, usually made on the bank of the pond; it consists of a mass of sticks or twigs, raised sufficiently high to prevent its being overflowed during any rise of the water. They require plenty of room and a secluded place where they can go unmolested from dogs or animals of prey and will breed freely, but when they are interfered with. they will seldom lay at all. They must also be kept separate during breeding season, as they are very quarrelsome among themselves. Two or more pair in one pen will never do. A female swan lays from 12 to 18 eggs in March, April and May, and the eggs hatch within nearly six weeks. The young are ted the same as you would a flock of geese. They are very profitable birds to raise, command high prices and in great demand.

Swans generally pair for life, their whole behavior offering a beautiful example of conjugal fidelity. The two birds show the greatest affection for each other, always swimming in company, and caressing each other with their bills and necks in the most interesting manner, though the male is, of course, the more powerful and courageous. Both birds help to prepare the nest, the male chiefly gathering the materials, while the female seems to take the chief part in the actual construction. Six to nine eggs are laid, very thick in shell, and generally of a dirty white color. sometimes pale green. The time of incubation has been differently stated, fixing it at thirty-five days, though some say forty-two. The young, when hatched are very thickly covered with down, and are generally taken to the water by the mother when only a day or two old. There they are watched over by both parents with the greatest care until grown enough to take care of themselves. 


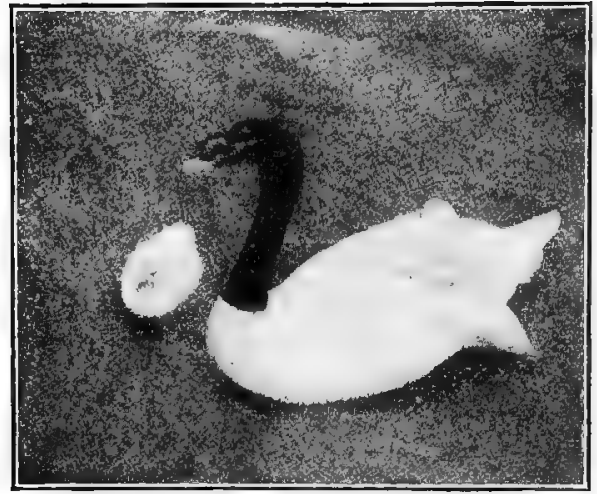

BLACK NECK SWAN AND YOUNG
Like their relative the ducks, they are quite free from disease and hardy. They are not great layers, hence not very prolific, and the grower must get a good price for the stock. If the first litter is taken away they will lay a second lot. The eggs are greenish like those of ducks, and the young are dark colored but become pure white when grown. The common swan is always white but there are swans of black or mixed color from Australia and South America. The swans, although awkward on land are among the most graceful of birds in their chosen element, while swimming about with curving neck and partly raised wings.

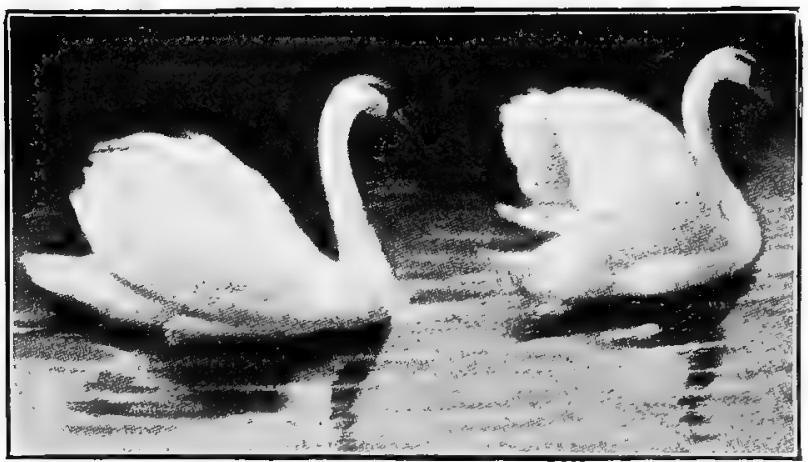

PURE WHITE SWANS

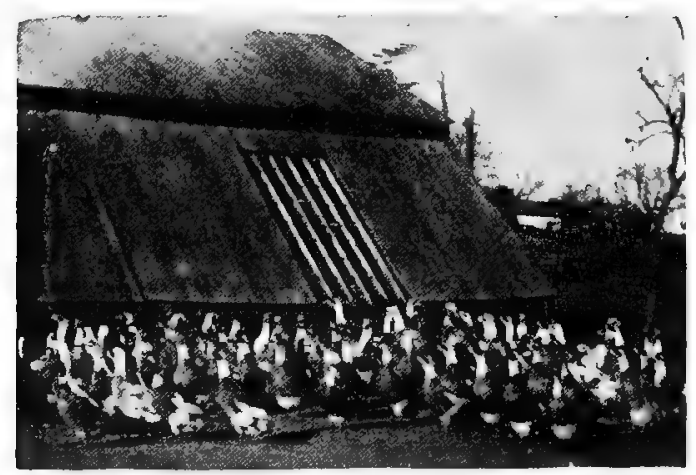

A FLOOK OF INDIAN RUNNER DUCKS 


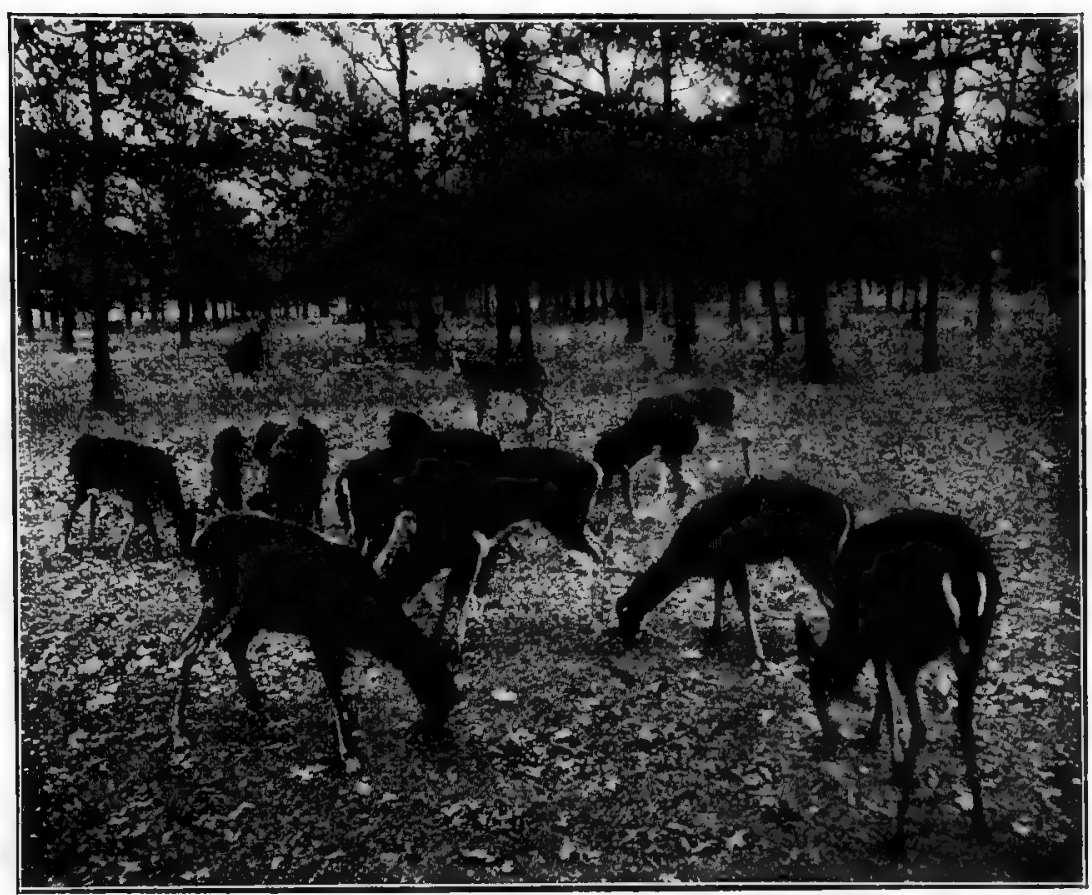

DEER FARMING

The raising of deer is now tried by a number of enthusiastic cattle breeders, some claim that twenty deer can be kept at the cost of one cow, and that waste land which yields little or no profit can be used for the purpose. The U.S. Department of Agriculture has issued a bulletin on deer farming, this pamphlet is quite complete on the subject and gives valuable information. Send for a copy, It is free.

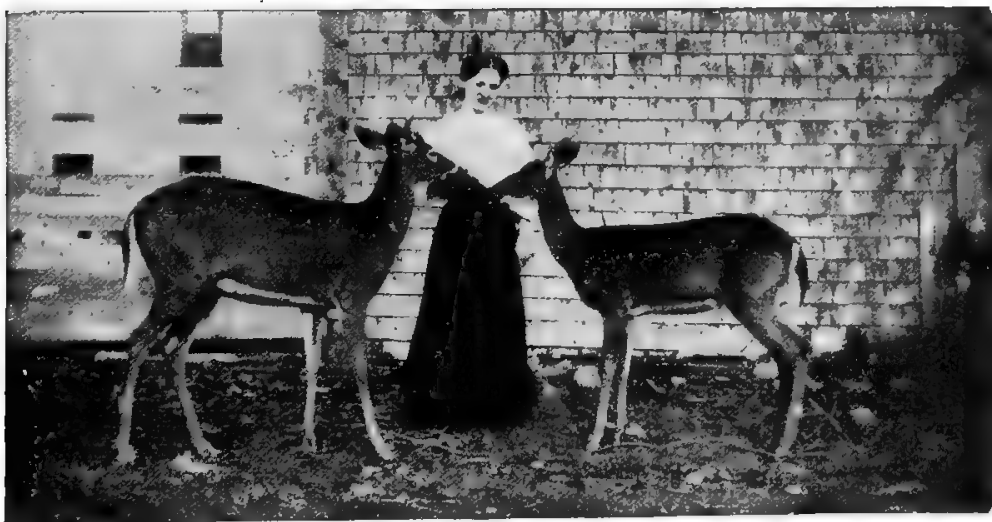

TAME DEER RAISED IN MAINE

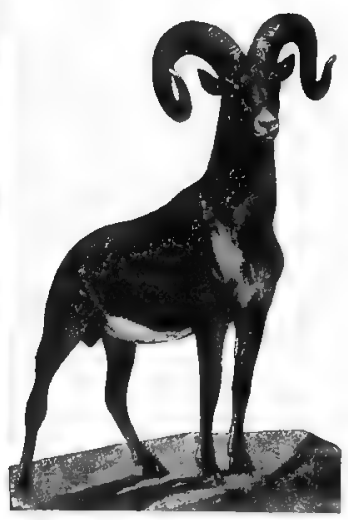

MOUNTAIN GOAT

Cuts at one-quarter price, of all kinds of Birds, Animals, Poultry, Pigeons, Dogs, etc. Also colored cuts.

Ferd. J. Sudow, Poughkeepsie, N. Y. 


\section{Japanese Ring Dove Breeding}

These doves breed about six times a year; lay two eggs to a setting; the eggs hatch within twelve days, and the young grow uniusually quick. They require warm climate and cannot stand much cold. On account of the beautiful fawn color the feathers and skin of ring doves

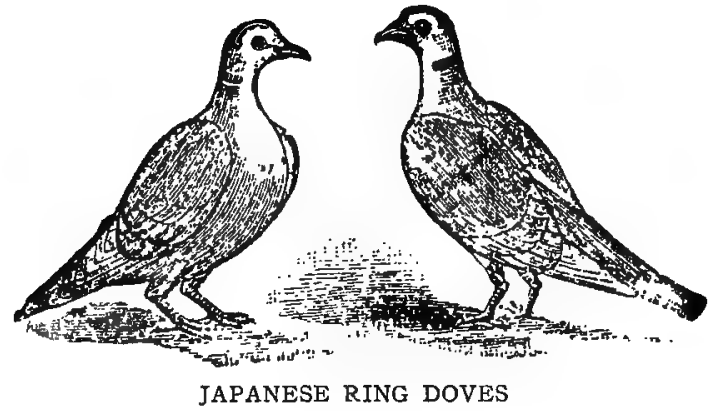

are largely used for the American millinery trade. They are today bred in great quantities in Italy, principally for that purpose. The price of skins bring from 40 to 65 cents each.

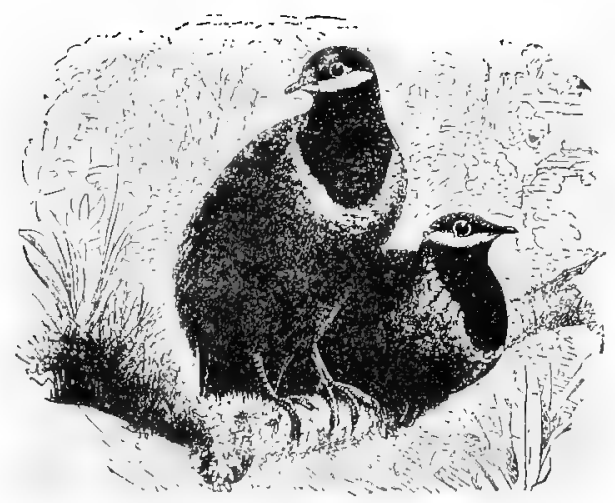

CUBAN DOVES

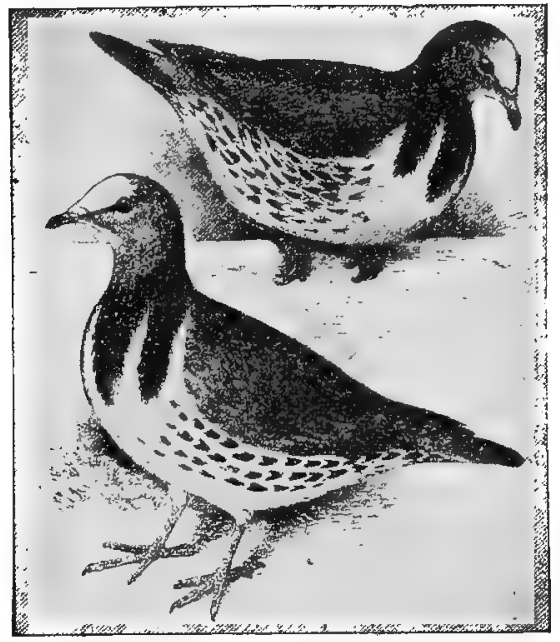

WONGA DOVES-NATIVE OF AUSTRALIA

Doves can be domesticated same as pigeens and require the same care. They can be given their liberty to fly at large when thoroughly accustomed to their loft, and are exceedingly attractive pets. It is very amusing to see them fly about, and unlike pigeons they will light in trees, and become so tame that they will fly on their keeper's shoulder to be fed; they make a peculiar laughing and cooing noise, on account of which they are called in Germany Lach-Taube, translated laughing dove.

Besides the doves above illustrated we have the wild turtle doves and pure white doves. 


\section{Questions and Answers}

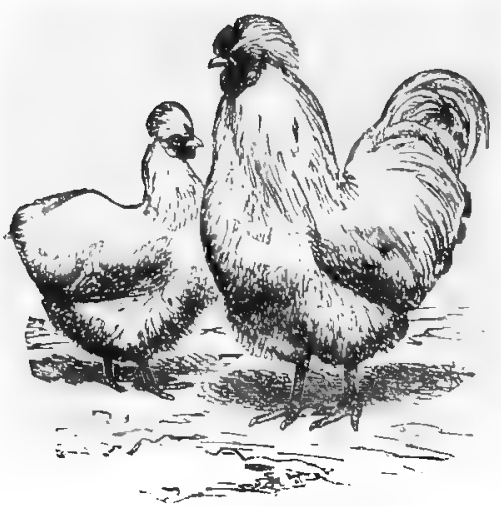

JAPANESE SILKIES

Make good foster mothers for pheasants
Q. What can I feed in place of ant eggs?

A. Feed meal worms.

Q. Can I keep golden and silver pheasants in one pen?

A. All varieties of pheasants should be kept separate, at least during breeding season. stuff?

Q. What is the best way of feeding green

A. Seed down grass or clover in boxes and place it in the aviary.

Q. What is the best remedy for cancer?

A. Swab the throat with one part Listerine and four parts water.

Q. What is the best bait for catching cats?

A. Use fresh fish.

Q. When do pheasants begin to lay?

A. All pheasants commence to lay in April till August.

Q. Why do you advise shipping coops for pheasants to be fifteen inches high?

.A. Because in order to digest their food and extend their stomach they should stand erect.

Q. What is the best way of providing shade for the aviary?

A. Put cheap muslin on top of wire, and fasten it to same.

Q. How much do pheasants weigh?

A. They vary in size according to varieties, their weight is from $1 \frac{1}{2}$ to $15 \mathrm{lbs}$.

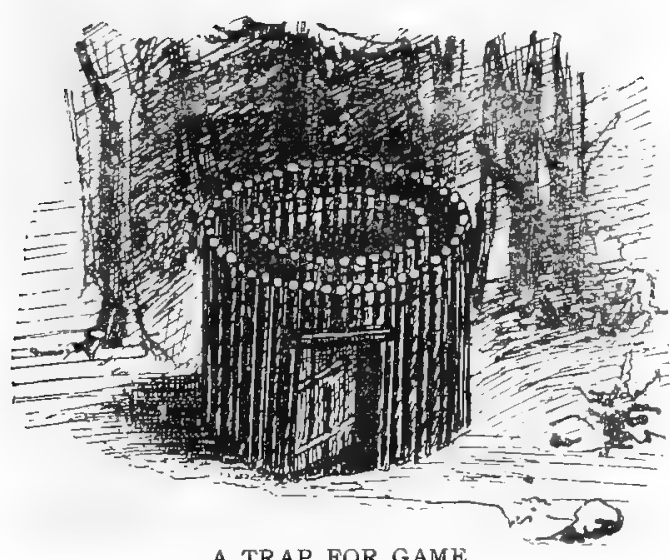

A TRAP FOR GAME

This illustration shows a trap for big game of all kinds. The bait is placed in the middle part. The trap has to be built according to the size of the game to be trapped. After entering the trap the animal cannot get out again, because passing the door will push it shut.

In a great many instances the poultry and pheasant business is a case of cart before the horse, particularly when it comes to shipping birds. On one occasion I had pheasants sent to me in a trunk, and again in something like a safe, all the birds arriving dead. To be successful in the pheasant industry, practicability must be exercised to the very utmost, to have things handy, easy to clean and to look for improvements right along.

What I have told you comes right from my practical experience and observation of handling a pheasant plant, and doing the actual industrious pheasant work, and not from a neat feather-dusted polished-oak office desk and spring chair and a handsome stenographer alongside of it. 


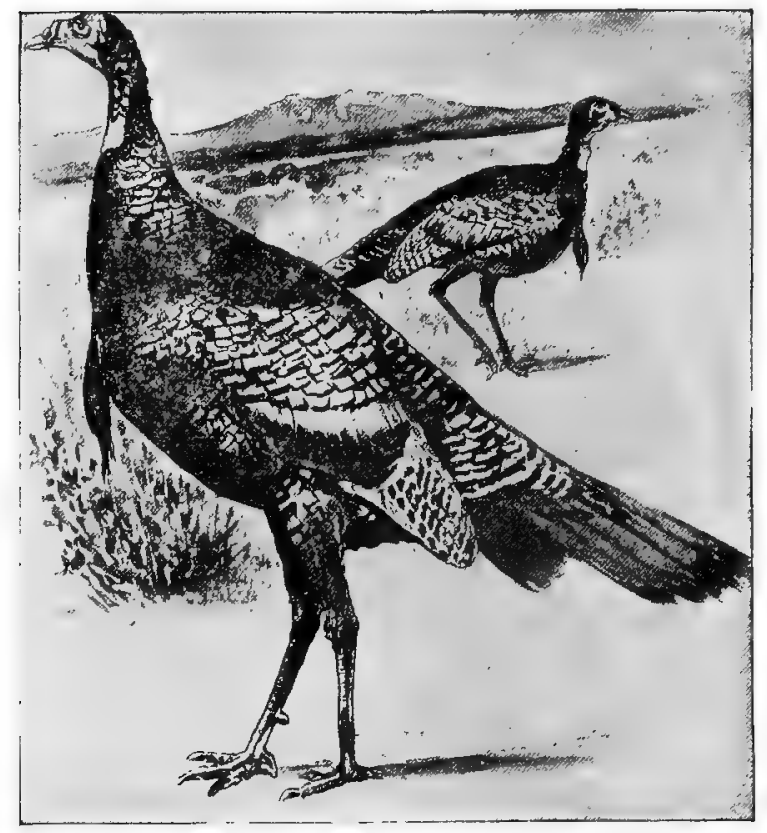

WILD TURKEYS-Can be raised in captivity-Bring enormous prices for stocking purposes

A sample of a long. beautiful, wearisome letter such as I receive in my daily mail. Ferd. Sudow,

Dear Sir:-

I would like to raise valuable pheasants or save the eggs for you (if you supply th stock) or both. I take an active interest in very fine precious birds. In case you wish that I should care for such birds-the coming winter-I will do so. Provided you pay for the building of the pens-and I want them right-Instead of getting $\$ 5.00$ a dozen for the eggs I prefer a different arrangement. Give me a stipulated amount each month-say $\$ 150.00$ a year-in return for care given to your breeder and for saving eggs. I also will hatch and raise for you what you want.

I desire to care for birds. I wish to live in my charming studio-just across from my home-and I cannot afford to do this. We have much property but are land poor.

If I could get $\$ 150$ a year I could do very well in all ways. I will not charge for the feed given.

I seldom go away from home and have experience with pheasants. I have plenty of land. I am not afraid of the responsibility. I am used to birds for 15 years-silkies and Chinese pheasants and like that-pigeons, etc.

All I need is explicit directions - such as you use yourself. I have already sent word to Mr. Davenport-the great pheasant owner, and it is likely he will secure my aid. Whichever writes first gets my help. I am a literature woman, very quiet and love beautiful birds. I think life is hardly worth living without birds. I cannot afford to stock. It is expensive to buy. In case you send stock to me let it be of the golden, silver, amherst and any other lovely variety. I should also like pet chip-munks and angora cats. In fact I am crazy over pets. I like gold fish but not the foreign varieties, they are too delicate and worry a body. You must build my pens as I want them. My Chinese pheasants are five years old.

Sincerely yours,

One full of literary. 

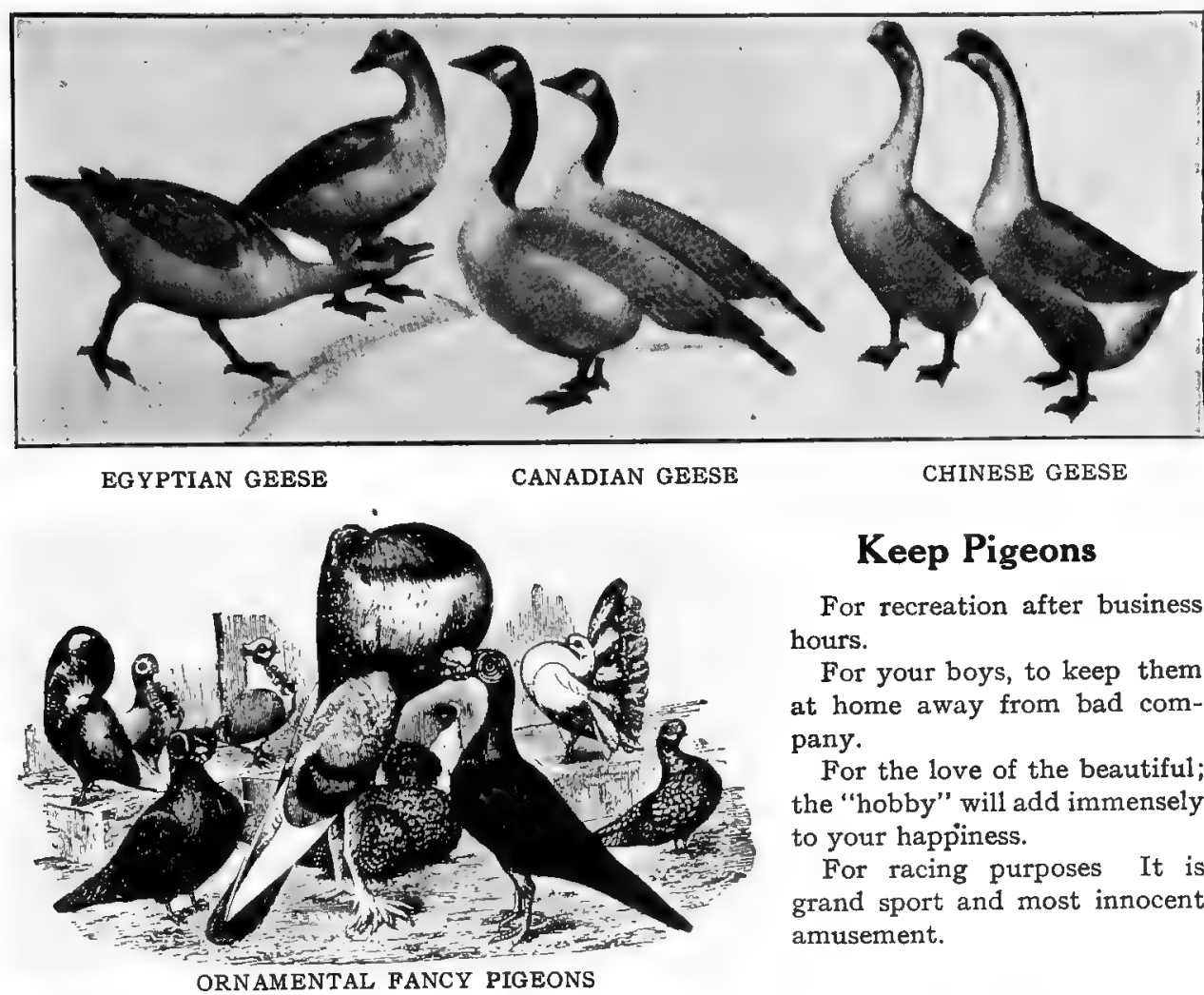

CHINESE GEESE

\section{Keep Pigeons}

For recreation after business hours.

For your boys, to keep them at home away from bad company.

For the love of the beautiful; the "hobby" will add immensely to your happiness.

For racing purposes It is grand sport and most innocent amusement.

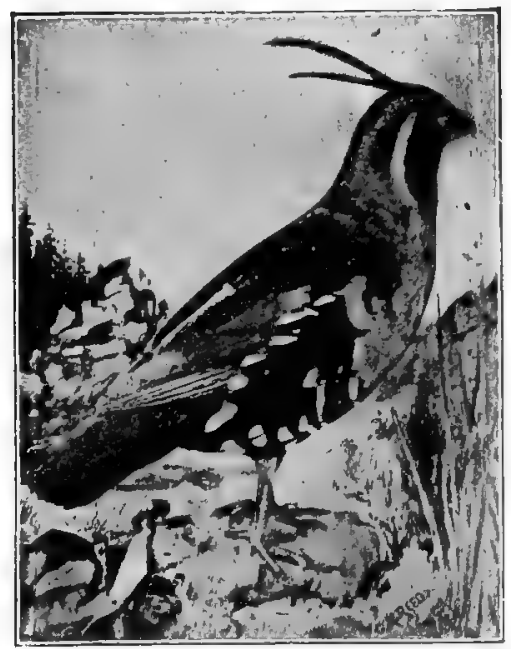

Pheasants and pigeons go well together.

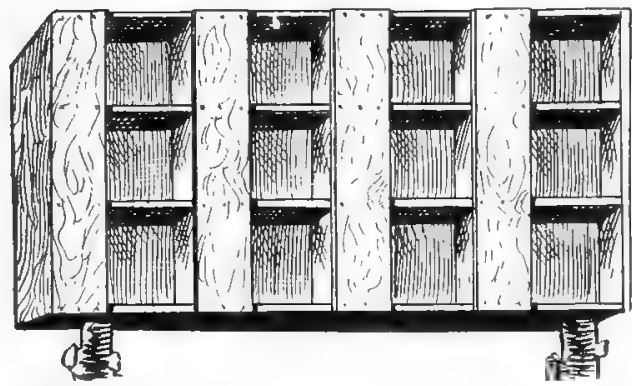

MOST PRACTICAL PIGEON NESTS

MOUNTAIN OUAIL

Quail will stand confinement and the young can be raised in captivity. Quailology is the best book treating on the breeding of quail. 
Complete Work on Pheasants, their natural history, treating on all points of breeding and habits. Illustrated with 24 full-page engravings, colored plates, drawn from life by J. G. Millias, 260 pages-bound in leather. $\$ 4.00$ postpaid.

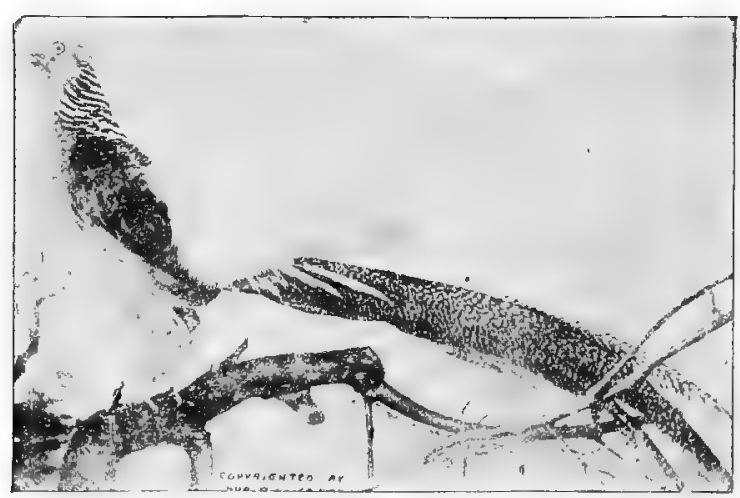

A beautiful picture of the golden pheasant, the king of all birds, in brilliant, natural colors of crimson, red and orange, almost life size, a great attraction for your home, 30 cents postpaid. You will never tire of looking at this handsome picture. It affords you great pleasure, if you are a lover of birds.

THE GOLDEN PHEASANT KING OF THE PHEASANT FAMILY

50 beautiful colored postal cards postpaid for $40 \mathrm{c}$ of many varieties of pheasants, quail swans, pigeons, ducks, turkeys, poultry, etc., and a scheme, how to make money "Quick," by mail goes with it.

Recipe for Killing Lice by fumigation, 15 cents; harmless to birds; no handling fowl or painting roosts necessary. All you do is to remave the cork. The Best Lice Killer Out.

Cuts of all varieties of pheasants, ducks, etc., in colors. $\$ 2.75$ per set, worth $\$ 25.00$. Half tone cuts, $60 \mathrm{c}$.

MAGIC FISH LURE-Bait Lure and you will go home basket. It attracts fish the

Try it,

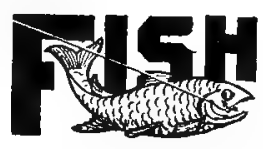

your hook with Magic Fish with a merry heart and a full same as sugar does flies.

30c. by mail.

\section{NEW DISCOVERY FOR THE DESTRUCTION OF RATS AND MICE.}

Your premises cleared in the surest and easiest way. Non-poisonous! Effective! I have a remedy which will drive the rats and mice from your premises. Not kill them, mind you, to cause offensive odors, but drive them out and keep them out Far better than cats, dogs, traps or dangerous poisons. Merely applied to wads of cotton and introduced into the haunts of rats and mice, it causes an immediate exodus of these annoying and destructive pests. Receipt by mail $20 \mathrm{c}$.

Sure cure to drive ground-moles out of your lawns. Receipt $25 \mathrm{c}$. by mail.

\section{UNITED STATES PHEASANTRY}

Poughkeepsie, Dutchess Co., N. Y.

This book bound in leather $\$ 2.00$ by mail. Agents and Canvassers wanted to sell this book. Big commiseion. 


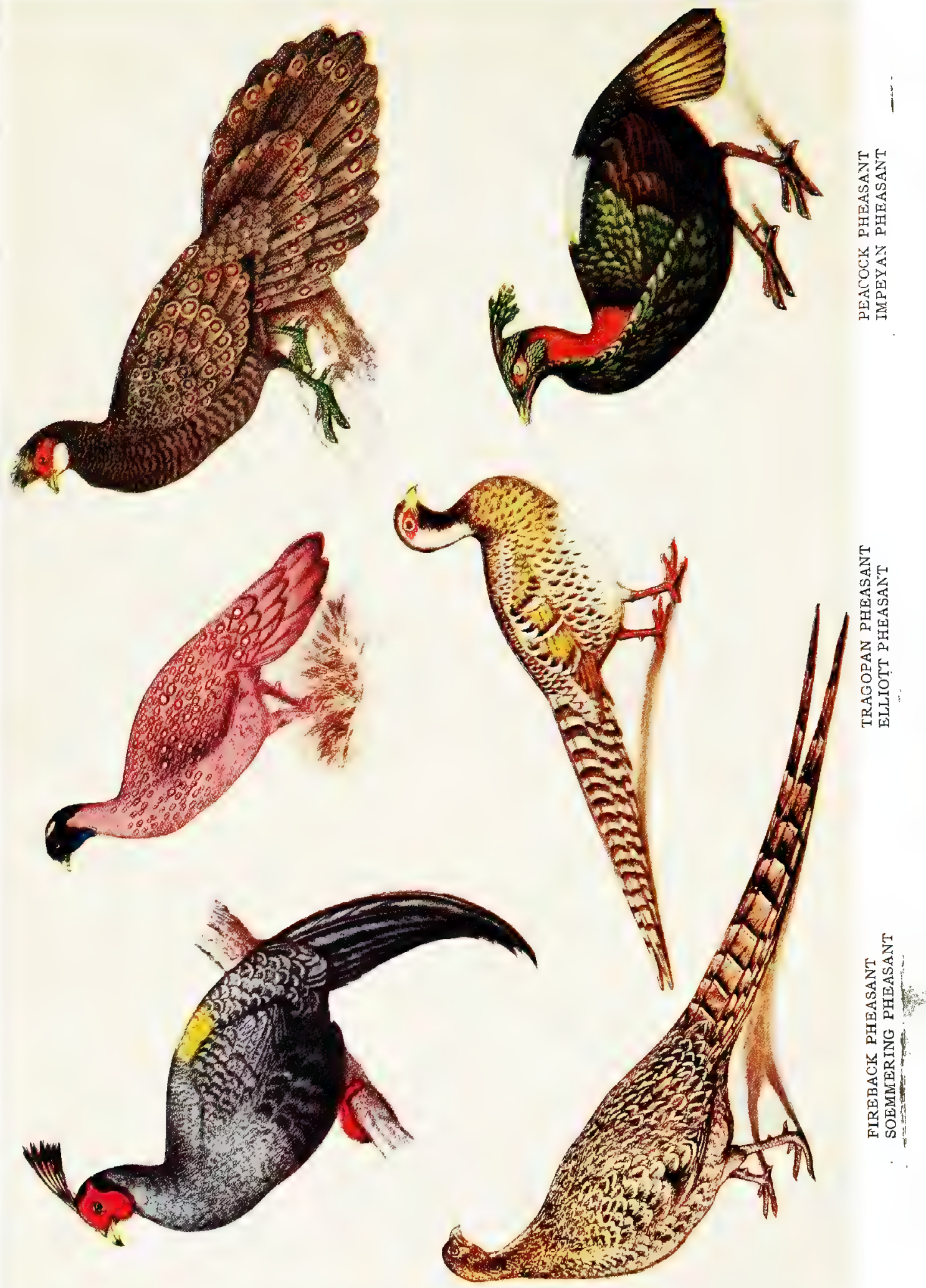



